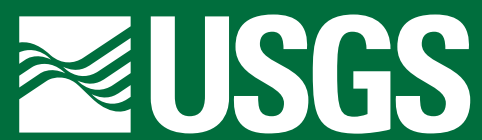

Prepared in cooperation with the

New Hampshire Department of Environmental Services and the

New Hampshire Department of Health and Human Services

\title{
Simulated Hydrologic Response to Climate Change During the 21st Century in New Hampshire
}



Scientific Investigations Report 2017-5143 


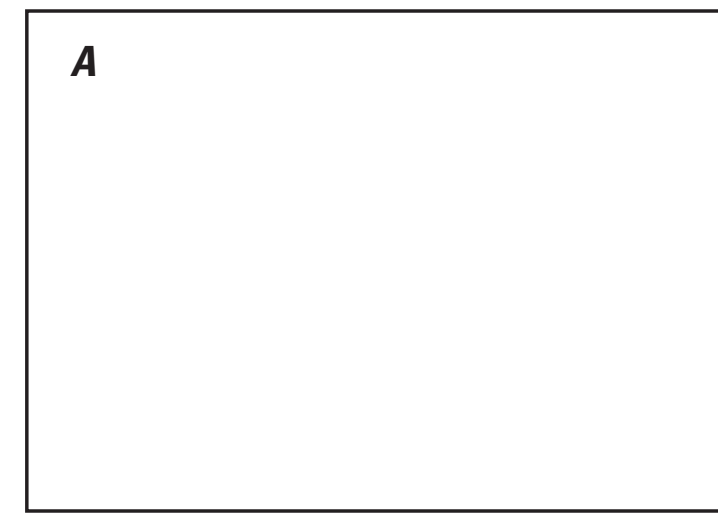

B
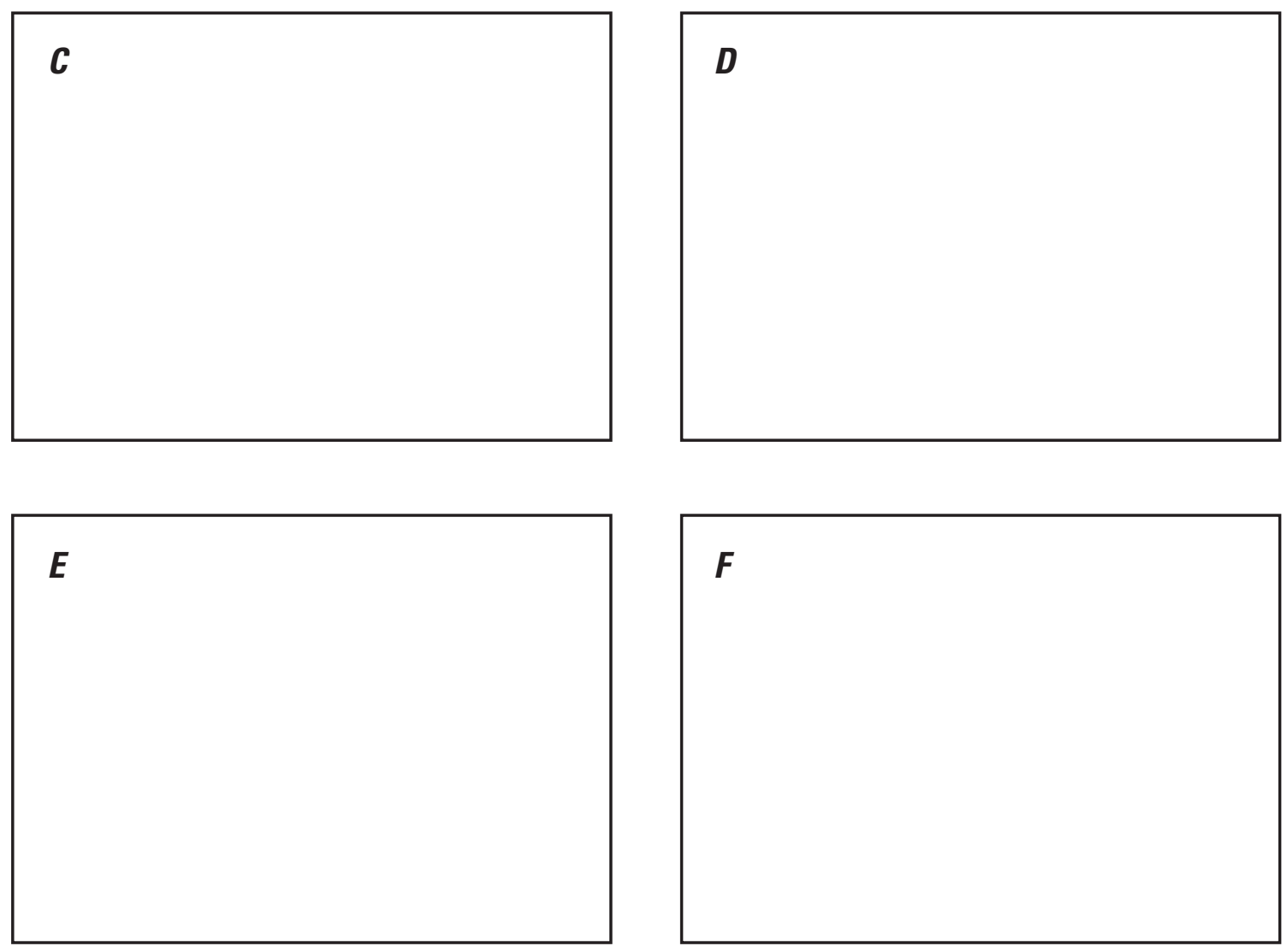

Front cover. View looking at the western side of Mount Washington as seen from Bretton Woods, New Hampshire, including the track of the Mount Washington Cog Railway to the left of the summit; photograph by user:wwoods, Wikimedia Commons, CC-BY-SA-3.0 / GFDL.

Back cover. $\quad A$, View of the Suncook River in Epsom, N.H., where a flood in 2006 changed the course of the river; photograph by Robert H. Flynn, U.S. Geological Survey (USGS).

$B$, View of Lake Winnipesaukee from Lake Shore Park, looking north toward Rattlesnake Mountain; photograph courtesy of user SteveA, used with permission by Don Zimmer from www.winnipesaukee.com.

$C$, Communications hut at the summit of Mount Washington; photograph by David M. Bjerklie, USGS.

$D$, Flooded USGS streamgage at Lamprey River near Newmarket, N.H.; photograph by Robert H. Flynn, USGS.

E, Ellis River near Pinkham Notch, N.H.; photograph by David M. Bjerklie, USGS.

F, Headwaters of the Ammonoosuc River in Sargents Purchase, N.H.; photograph by David M. Bjerklie, USGS. 


\section{Simulated Hydrologic Response to Climate Change During the 21st Century in New Hampshire}

By David M. Bjerklie and Luke Sturtevant

Prepared in cooperation with the

New Hampshire Department of Environmental Services and the

New Hampshire Department of Health and Human Services

Scientific Investigations Report 2017-5143 


\title{
U.S. Department of the Interior \\ RYAN K. ZINKE, Secretary
}

\section{U.S. Geological Survey William H. Werkheiser, Deputy Director exercising the authority of the Director}

\author{
U.S. Geological Survey, Reston, Virginia: 2018
}

For more information on the USGS - the Federal source for science about the Earth, its natural and living resources, natural hazards, and the environment-visit https://www.usgs.gov or call 1-888-ASK-USGS.

For an overview of USGS information products, including maps, imagery, and publications, visit https://store.usgs.gov.

Any use of trade, firm, or product names is for descriptive purposes only and does not imply endorsement by the U.S. Government.

Although this information product, for the most part, is in the public domain, it also may contain copyrighted materials as noted in the text. Permission to reproduce copyrighted items must be secured from the copyright owner.

Suggested citation:

Bjerklie, D.M., and Sturtevant, Luke, 2018, Simulated hydrologic response to climate change during the 21st century in New Hampshire: U.S. Geological Survey Scientific Investigations Report 2017-5143, 53 p., https://doi.org/10.3133/ sir20175143.

ISSN 2328-0328 (online) 


\section{Acknowledgments}

The authors would like to thank the project cooperators represented by Steven Couture of the New Hampshire Department of Environmental Services and Matthew Cahillane of the New Hampshire Department of Health and Human Services. In addition, valuable input and consultation were provided by Cameron Wake of the Sustainability Institute, University of New Hampshire; Fay Rubin of the Earth Systems Research Center at the University of New Hampshire; and the entire stakeholder group assembled for this project. The stakeholder group is acknowledged for supporting the project, for providing helpful guidance and suggestions regarding data and information needs, and for feedback. This publication was supported by Centers for Disease Control and Prevention (CDC) grant number \#NUE1EH001332-01 from the National Center for Environmental Health in Atlanta, Georgia. The contents of the report do not necessarily represent the official views of the CDC. The authors would also like to thank Jacob LaFontaine, Robert Dudley, Sara Levin, Gregory Stewart, Gardner Bent, and Thomas Mack of the U.S. Geological Survey for valuable review comments and suggestions during the course of this study. 



\section{Contents}

Acknowledgments …......................................................................................................................

Abstract

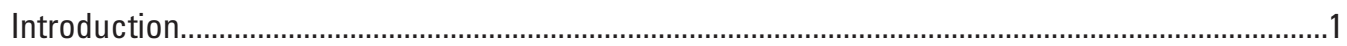

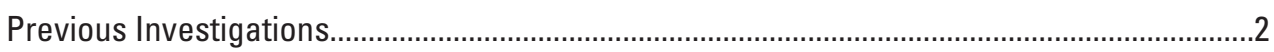

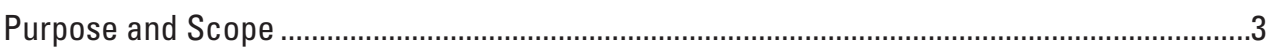

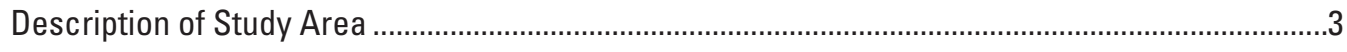

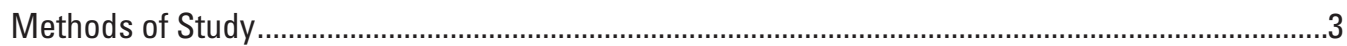

Precipitation Runoff Modeling System ...................................................................................

Justification and Model Applicability.............................................................................

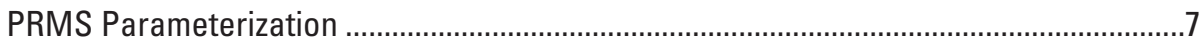

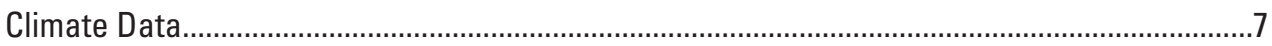

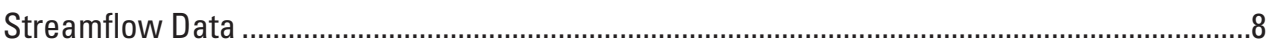

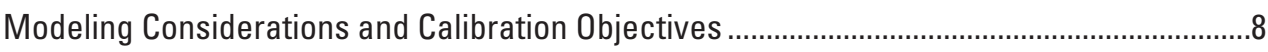

Calibration of the New Hampshire PRMS Model .................................................................

Evaluation of the New Hampshire PRMS Model.....................................................................

Simulated Hydrologic Response to Climate Change .................................................................18

Model Sensitivity to Land-Use Change and Effects Relative to Climate Change ....................19

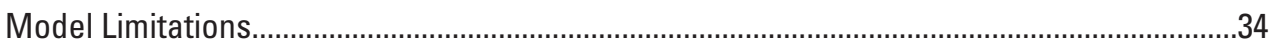

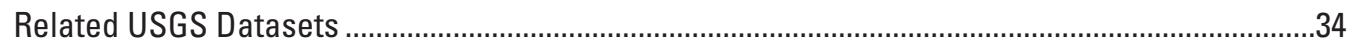

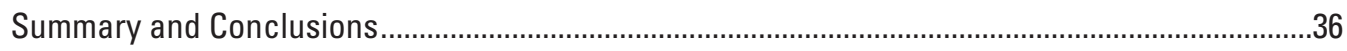

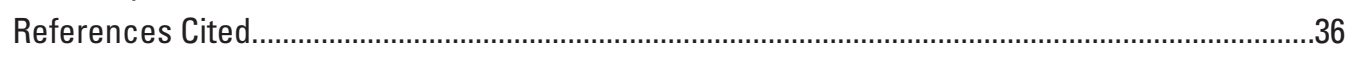

Appendix 1. Evaluation of the Jensen-Haise Method of Estimating Potential

Evapotranspiration in New England Using the Precipitation Runoff Modeling System.....41

\section{Figures}

1. Map showing the location of hydrologic response units and the calibration streamgages used in the Precipitation Runoff Modeling System model of New Hampshire

2. Graphs showing $A$, simulated mean daily streamflow in relation to measured mean daily streamflow and $B$, standard deviation of simulated streamflow in relation to the standard deviation of measured mean daily streamflow at 27 calibration streamgages in New Hampshire for the period of record for each streamgage.

3. Graph showing the simulated monthly mean streamflow in relation to the measured monthly mean streamflow at the 27 calibration streamgages in New Hampshire for the period of record at each streamgage.

4. Map showing the spatial distribution of Nash-Sutcliffe efficiency statistic for 27 streamgages in New Hampshire at $A$, the daily time step and $B$, the monthly time step.

5. Map showing the spatial distribution of the mean of the log residuals for 27 streamgages in New Hampshire at $A$, the daily time step, and $B$, the monthly time step. 
6. Maps showing the spatial distribution of changes in simulated mean streamflow at the 27 calibration streamgages in New Hampshire between the current period and the end-of-century period using two general circulation models and the two emission scenarios: $A$, coupled general circulation model (CGCM) RCP 4.5, $B$, CGCM RCP 8.5, C, Geophysical Fluid Dynamics Laboratory (GFDL) model RCP 4.5 , and $D$, GFDL RCP 8.5

7. Maps showing the spatial distribution of change in simulated mean groundwater recharge at hydrologic response units in New Hampshire between the current period and the end-of-century period, using two general circulation models (GCMs) and the two emission scenarios: $A$, combined general circulation model (CGCM) RCP 4.5, B, CGCM RCP 8.5, C, Geophysical Fluid Dynamics Laboratory (GFDL) RCP 4.5, and D, GFDL RCP 8.5

8. Maps showing the spatial distribution of percent changes in simulated monthly snowfall at hydrologic response units in New Hampshire between the current period and the midcentury and end-of-century period, using two general circulation models (GCMs) and the two emission scenarios: $A$, March, CGCM RCP 4.5, 2046 to 2065; $B$, March, CGCM RCP 4.5, 2081 to 2100; $C$, November, GFDL RCP 8.5, 2046 to 2065; D, February, GFDL RCP 4.5, 2046 to 2065; and $E$, February, GFDL RCP 4.5, 2081 to 2100

\section{Tables}

1. General circulation models used for climate change scenarios in New Hampshire .......5

2. Calibrated parameters for the Precipitation Runoff Modeling System ... .9

3. Description of 27 selected streamgages with streamflow calibration statistics in New Hampshire ....

4. Simulated mean change in daily streamflow and standard deviation using two emission scenarios and five general circulation models, plus a composite, for 27 streamgages in New Hampshire, by 20 -year periods

5. Simulated change in mean monthly streamflow, in percent, for 27 selected streamgages in New Hampshire, composited from simulations made from all five general circulation models and two scenarios from 2046 to 2065 and 2081 to 2100 .......18

6. Standard deviation of the percent change in the mean of the monthly streamflows at 27 selected streamgages in New Hampshire, composited from simulations made from all five general circulation models and two scenarios from 2046 to 2065 and 2081 to 2100

7. Simulated percent changes in average recharge in New Hampshire for 20-year periods using simulations made from five general circulation models and two emission scenarios.

8. Simulated percent change in average snowfall in New Hampshire for 20-year periods using two emission scenarios and five general circulation models, in inches of snow

9. Description of datasets of simulated hydrologic data from 1976 to 2005 and 2010 to 2099 


\section{Conversion Factors}

U.S. customary units to International System of Units

\begin{tabular}{lll}
\hline \multicolumn{1}{c}{ Multiply } & \multicolumn{1}{c}{ By } & \multicolumn{1}{c}{ To obtain } \\
\hline inch (in.) & 2.54 & centimeter $(\mathrm{cm})$ \\
foot (ft) & 0.3048 & meter $(\mathrm{m})$ \\
mile (mi) & 1.609 & kilometer $(\mathrm{km})$ \\
square mile $\left(\mathrm{mi}^{2}\right)$ & 2.590 & square kilometer $\left(\mathrm{km}^{2}\right)$ \\
cubic foot per second $\left(\mathrm{ft}^{3} / \mathrm{s}\right)$ & 0.02832 & cubic meter per second $\left(\mathrm{m}^{3} / \mathrm{s}\right)$ \\
\hline
\end{tabular}

Temperature in degrees Fahrenheit $\left({ }^{\circ} \mathrm{F}\right)$ may be converted to degrees Celsius $\left({ }^{\circ} \mathrm{C}\right)$ as follows:

$$
{ }^{\circ} \mathrm{C}=\left({ }^{\circ} \mathrm{F}-32\right) / 1.8 \text {. }
$$

\section{Datum}

Vertical coordinate information is referenced to the North American Vertical Datum of 1988 (NAVD 88).

Horizontal coordinate information is referenced to the North American Datum of 1983 (NAD 83).

Elevation, as used in this report, refers to distance above the vertical datum.

\section{Abbreviations}

CGCM coupled general circulation model

CMIP3 Coupled Model Intercomparison Project phase 3

CMIP5 Coupled Model Intercomparison Project phase 5

CNRM Centre National de Recherches Météorologiques

ESM Earth system model

GCM general circulation model

GFDL Geophysical Fluid Dynamics Laboratory

GIS geographic information system

HRU hydrologic response unit

IPCC Intergovernmental Panel on Climate Change

NHDES New Hampshire Department of Environmental Services

NHDHHS New Hampshire Department of Health and Human Services

NLCD National Land Cover Data

NRCC Northeast Regional Climate Center

NRMSE normalized root mean square error 


$\begin{array}{ll}\text { NSE } & \text { Nash-Sutcliffe efficiency } \\ \text { PBIAS } & \text { percent bias } \\ \text { PET } & \text { potential evapotranspiration } \\ \text { PRMS } & \text { Precipitation-Runoff Modeling System } \\ \text { RCP } & \text { representative concentration pathway } \\ \text { RMSE } & \text { root mean square error } \\ \text { RSR } & \text { ratio of root mean square error to the standard deviation } \\ \text { SRES } & \text { Special Report on Emissions Scenarios } \\ \text { USGS } & \text { U.S. Geological Survey }\end{array}$




\title{
Simulated Hydrologic Response to Climate Change During the 21st Century in New Hampshire
}

\author{
By David M. Bjerklie and Luke Sturtevant
}

\section{Abstract}

The U.S. Geological Survey, in cooperation with the New Hampshire Department of Environmental Services and the Department of Health and Human Services, has developed a hydrologic model to assess the effects of short- and long-term climate change on hydrology in New Hampshire. This report documents the model and datasets developed by using the model to predict how climate change will affect the hydrologic cycle and provide data that can be used by State and local agencies to identify locations that are vulnerable to the effects of climate change in areas across New Hampshire.

Future hydrologic projections were developed from the output of five general circulation models for two future climate scenarios. The scenarios are based on projected future greenhouse gas emissions and estimates of land-use and land-cover change within a projected global economic framework. An evaluation of the possible effect of projected future temperature on modeling of evapotranspiration is summarized to address concerns regarding the implications of the future climate on model parameters that are based on climate variables. The results of the model simulations are hydrologic projections indicating increasing streamflow across the State with large increases in streamflow during winter and early spring and general decreases during late spring and summer. Wide spatial variability in changes to groundwater recharge is projected, with general decreases in the Connecticut River Valley and at high elevations in the northern part of the State and general increases in coastal and lowland areas of the State. In general, total winter snowfall is projected to decrease across the State, but there is a possibility of increasing snow in some locations, particularly during November, February, and March. The simulated future changes in recharge and snowfall vary by watershed across the State. This means that each area of the State could experience very different changes, depending on topography or other factors. Therefore, planning for infrastructure and public safety needs to be flexible in order to address the range of possible outcomes indicated by the various model simulations. The absolute magnitude and timing of the daily streamflows, especially the larger floods, are not considered to be reliably simulated compared to changes in frequency and duration of daily streamflows and changes in accumulated monthly and seasonal streamflow volumes.
Simulated current and future streamflow, groundwater recharge, and snowfall datasets include simulated data derived from the five general circulation models used in this study for a current reference time period and two future time periods. Average monthly streamflow time series datasets are provided for 27 streamgages in New Hampshire. Fourteen of the 27 streamgages associated with daily streamflow time series showed a good calibration. Average monthly groundwater recharge and snowfall time series for the same reference time period and two future time periods are also provided for each of the 467 hydrologic response units that compose the model.

\section{Introduction}

A coordinated effort is underway in New Hampshire to proactively prepare for the effects of climate change using several action plans (New Hampshire Climate Change Policy Task Force, 2009). A key component of the action plans is a vulnerability assessment of hydrologic responses to climate change. The U.S. Geological Survey (USGS) is a partner with the New Hampshire Department of Environmental Services (NHDES) and the New Hampshire Department of Health and Human Services (NHDHHS) in the development of models and maps to assess the effects of short- and long-term climate change on hydrology in New Hampshire. For this effort, the USGS, in cooperation with the NHDES and NHDHHS, conducted an investigation to predict how climate change will affect the hydrologic cycle and provide data that can be used by State and local agencies to identify locations across the State that are vulnerable to the effects of climate change.

Hydrologic models can be used to map and project climate change effects for areas that otherwise could be observed only from measurements made at discrete locations, often in somewhat rural watersheds. The USGS watershed model Precipitation Runoff Modeling System (PRMS) provides a method to extend trends observed at specific locations spatially and temporarily across a region. Additionally, hydrologic systems may no longer be considered stable and predictable (Milly and others, 2008), indicating that possible future hydrologic conditions need to be simulated and evaluated so that these future conditions can be considered in the planning and design of infrastructure and other projects. 
Through the application of the USGS PRMS for the State of New Hampshire, this study is designed to assess potential changes in the hydrologic cycle that result from projected climate change in New Hampshire. In addition, a limited sensitivity analysis was completed to compare changes associated with climate change to potential changes that may result from increases in impervious surface. The New Hampshire PRMS rainfall-runoff model is the method used to simulate the spatial and temporal distribution of streamflow, groundwater recharge, and snowfall across New Hampshire.

Researchers have used regional hydrologic models to map and assess the past and potential future trends in hydrologic variability as a result of climate change over large areas (Bjerklie and others, 2010a). Various types of hydrologic models have been used to couple simulated watershed processes with input data derived (downscaled) from general circulation models (GCMs; Hayhoe and others, 2006, 2007). As previously mentioned, this investigation uses the USGS PRMS to develop the New Hampshire regional rainfall-runoff simulations (Leavesley and others, 1983; Markstrom and others, 2015). The PRMS lends itself to the goals of this study because it can be parameterized at a wide range of scales with any scheme for subdividing the modeled area, often using subdivisions that correspond to watershed boundaries. The PRMS simulations are based on the spatial variation in measurable physical characteristics, including land cover, topography, soil, and geology, that can be quantified using geographic information systems (GISs). The PRMS simulates surface runoff, groundwater storage flux, snow cover, snowmelt, and streamflow, as well as other hydrologic variables. The PRMS model computes these water balance variables for all subdivisions that compose the watershed of interest, referred to as hydrologic response units (HRUs).

\section{Previous Investigations}

Hydrologic vulnerability from future climate scenarios has increasingly become a major point of research in New Hampshire and the Northeast (Neff and others, 2000). Mack (2009) assessed a future climate scenario for the seacoast region by simulating potential variations in groundwater recharge and water use. For the seacoast region of the State, Mack (2009) found that potential effects of climate change on groundwater by 2025 are likely to be more important for groundwater recharge than for water demand. Using a watershed runoff model to simulate groundwater recharge and snowfall in the Connecticut River Basin (western New Hampshire), Bjerklie and others (2010a) found that, from 1960 to 2007, in general, snowfall decreased and base flow (discharge to streams from groundwater) increased. These changes have not been distributed uniformly in time or space, and snowfall and base flow have marginally decreased or increased in some places in response to local conditions. Similarly, for the 57-year study from 1950 to 2006, Hodgkins and Dudley (2011) found increased base flow and stormflow in New England, and Dudley and Hodgkins (2013) found increased groundwater levels.

Hamilton and others (2010) reported on climate trends in New Hampshire; air temperature and precipitation increased throughout the 20th century, accelerating since 1970. Hamilton and others (2010) found indications of decreased snowfall from 1970 to 2009; however, they acknowledge that the trends in snowfall are complicated by inconsistencies. Jacobs and others (2014) found evidence of consistently decreasing snowfall across New Hampshire from 1955 to 2012, using data from NHDES and from the Hubbard Brook Experimental Forest.

Wake and others (2014a,b) indicated that the climate model consensus shows increasing air temperature and precipitation for New Hampshire in the future, at least until the year 2100. Bjerklie and others (2010a, 2015) projected that, in response to the climate change, groundwater recharge (and subsequently base flow) will continue to increase and snowfall will decrease in parts of New Hampshire and the Connecticut River Basin. These effects do not occur everywhere but depend on the results of the GCM (often referred to as a "global climate model") greenhouse gas emission scenarios that are coupled with land use and land cover within a projected global economic framework (Solomon and others, 2007; Stocker and others, 2013). Similar projections are reported by the U.S. Geological Survey (2016) on the basis of the Intergovernmental Panel on Climate Change (IPCC) fifth climate change assessment report (Stocker and others, 2013) and the National Climate Assessment (Melillo and others, 2014). Campbell and others (2011) report that, in the White Mountains of New Hampshire, precipitation has increased during the latter half of the 20th century, resulting in increased water yield, and the upward trend in precipitation is expected to continue into the future. Researchers also report a decrease in evapotranspiration (ET) during the same period (Campbell and others, 2011; Melillo and others, 2014); however, they expect that ET will increase in the future in response to rising air temperatures (projected by GCMs) that possibly keep pace with increasing precipitation, offsetting continued increases in water yield.

Past trends show precipitation increases across much of the conterminous United States (Karl and Knight, 1998; Groisman and others, 2005). These trends have also been noted in more localized studies in parts of New England (Miller and others, 2002) and the State of New York (Burns and others, 2007). The measured step increase in streamflow that occurred around 1970 coincides with changes in the timing of snowmelt peaks in New England (Hodgkins and others, 2003). Projections from GCM simulations consistently indicate that the trends in precipitation, temperature, and total runoff will continue to increase in the northeastern United States (Hayhoe and others, 2006). Additionally, Demaria and others (2016) project increases in 3-day peak flows and decreases in 7-day low flows in the Northeast on the basis of future climate simulations from 16 GCMs. 
Changes in land and water use also could affect hydrologic conditions in the future. This is particularly true in areas with high populations, including areas within the Merrimack River and Piscataqua River Basins in New Hampshire. Claessens and others (2006) suggest that land-use change is not as effective as climate change and water use in causing changes in the water budget for an urbanizing watershed in Massachusetts; however, the balance of these effects likely will vary depending on the spatial distribution of climate change factors and degree of urbanization. In contrast, LaFontaine and others (2015) found that land-use change (characterized as increasing development and impervious surface) can have a great effect on total runoff generated from a watershed; however, stormwater management practices can largely mitigate this effect.

\section{Purpose and Scope}

A watershed scale hydrologic model using the PRMS was developed to assess the effects of climate change on hydrologic responses and vulnerability. The New Hampshire rainfall-runoff model developed in this study using the USGS PRMS provides information that will inform users on the potential effects of climate change on aspects of the hydrologic cycle in New Hampshire. The purpose of this report is to document the model, datasets, and application of PRMS that simulates future hydrologic conditions in the State. Projected changes in snowfall, mean streamflow, and mean groundwater recharge are shown in illustrations and tables. The study makes available hydrologic simulation data that reflect the projected future conditions so that State and local agencies can address specific vulnerabilities for specific locations across the State that might be susceptible to those vulnerabilities. A number of output datasets developed in this study are available from Bjerklie and Sturtevant (2017).

\section{Description of Study Area}

The physiography and general climate of New Hampshire have been described by Flanagan and others (1999), and that description is summarized in this report (fig. 1). New Hampshire can be divided into three broad physiographic regions: the White Mountains, the Connecticut River Valley and New England Uplands, and the Seaboard Lowlands. The White Mountain region is dominated by mountain landscapes with elevations (relative to the North American Vertical Datum of 1988 [NAVD 88]) ranging from approximately 1,500 feet (ft) to $6,300 \mathrm{ft}$ at the top of Mount Washington. The Connecticut River Valley is a relatively narrow incised valley on either side of the Connecticut River, which forms the western boundary of New Hampshire. The river flows through the White Mountain region and the New England Uplands, which are south of the White Mountains in New Hampshire. The New England Uplands region consists of undulating, hilly topography, ranging in elevation from less than $1,000 \mathrm{ft}$ to greater than
$2,000 \mathrm{ft}$. The Seaboard Lowlands region is lower in elevation, at less than $500 \mathrm{ft}$, and is less hilly than the New England Upland region.

The climate in the study area is continental because of prevailing westerly winds and is characterized by changeable weather, wide ranges in diurnal and annual temperatures, distinct seasonal trends that vary from year to year, and a fairly uniform distribution of precipitation throughout the year. The climate varies between the physiographic regions. Generally, precipitation is evenly distributed throughout the year across New Hampshire, yet there is variation in the average annual amount of precipitation because of the effects of terrain, elevation, and proximity to the ocean. The statewide average amount of precipitation is 40 to 50 inches per year (in/yr); however, average annual precipitation ranges from $42 \mathrm{in} / \mathrm{yr}$ in low-lying areas to greater than $60 \mathrm{in} / \mathrm{yr}$ near the summits of the White Mountains.

The amount of frozen precipitation is dependent on elevation, terrain, and latitude. Snowfall amounts (reported here as inches of snow that has fallen as opposed to depth of snowpack or snow as water equivalent) are generally greatest in January or February and are spatially variable, ranging from 20 to $50 \mathrm{in} / \mathrm{yr}$ near the coast in the Seaboard Lowlands, from 30 to $70 \mathrm{in} / \mathrm{yr}$ in the Connecticut River Valley and New England Uplands, and from 50 to $110 \mathrm{in} / \mathrm{yr}$ in the White Mountains. Snowmelt is a major source of water in streams during late winter and early spring.

Temperatures vary widely on an annual basis (Bjerklie and others 2010a; Wake and others 2014a,b). Temperature data from 1961 to 1990 indicate that the warmest month in the study area is July, and the coldest month is January. On the basis of monthly average temperatures, winter temperatures are more variable across the study area than summer temperatures.

\section{Methods of Study}

A statewide hydrologic model was developed for the river watersheds of New Hampshire (fig. 1) by using the PRMS (Leavesley 1983; Markstrom and others, 2015). The calibration of the New Hampshire regional model is based on daily streamflow records from USGS streamgages for the period of record from 1981 to 2000. Future hydrologic conditions are simulated using daily simulated air temperature and precipitation from GCMs (Solomon and others, 2007; Stocker and others, 2013). Given the uncertainty in climate modeling, it is desirable to use more than one GCM to obtain a range of potential future climatic conditions (Hay and others, 2011; Bjerklie and others, 2012; Hay and others, 2014). The future time periods are compared with the current reference (baseline) time period so that projected change can be evaluated in a self-consistent hydrologic framework described by the PRMS model. The output data include estimates of daily base flow, total river streamflow, and snowfall for each HRU in the model. 


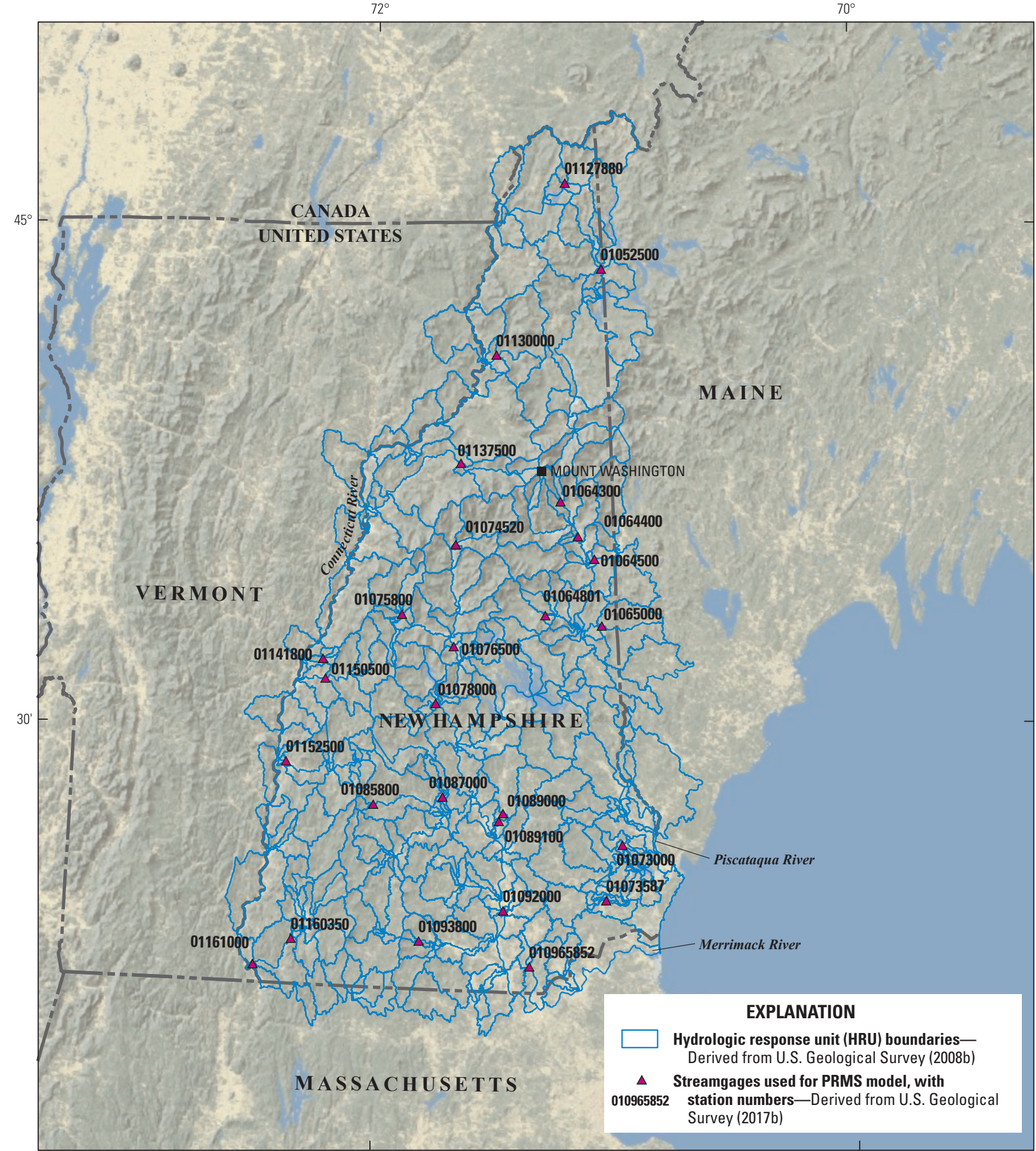

Base from U.S. Geological Survey The National Map digital data Albers equal area conic projection North American Datum 1983

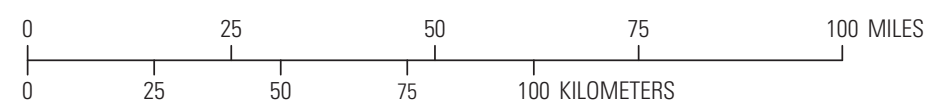

Figure 1. The location of hydrologic response units and the calibration streamgages used in the Precipitation Runoff Modeling System (PRMS) model of New Hampshire. USGS, U.S. Geological Survey. 
The PRMS generates daily runoff from input of daily air temperature and precipitation data. The New Hampshire PRMS model is subdivided into small subwatersheds (catchments) that can be aggregated into larger river watersheds of interest. As previously stated, these subwatersheds are the basic computational unit of the model and are referred to as HRUs. The statewide model also includes several hundred river reaches that constitute the simulated river network that routes runoff generated from the HRUs downstream. The statewide model consists of 467 HRUs (fig. 1).

The streamgages used for calibration have at least 5 years of daily data, are widely distributed across the State, and are not significantly affected by lake and reservoir storage or water diversions because these are not explicitly modeled in the PRMS. The parameters for each HRU in the model were defined using a GIS (Steve Markstrom and Lauren Hay, USGS, written commun., 2013) or were adjusted on the basis of considerations developed by Bjerklie and others (2010a, b). The adjusted parameter is the monthly Jensen-Haise potential evapotranspiration (PET) coefficient (Bjerklie and others, 2010a), which limits the amount of daily PET available each month. The model calibration was evaluated on the basis of a 20-year mean (1981-2000) of simulated daily streamflows compared to measured streamflows from a set of 27 USGS calibration streamgages (fig. 1).

In this study, five GCMs were used to develop input datasets for the PRMS that represent potential future climate conditions (table 1). Each GCM simulates a representative current reference conditions (1981-2000) dataset and two future scenarios, including IPCC scenarios RCP 4.5 and RCP 8.5 (RCP stands for representative concentration pathway). The scenarios were developed taking into consideration various greenhouse gas emission levels and changes in socioeconomic conditions (land use and land cover within a projected economic framework) over time. For the RCP 4.5 scenario, it was assumed that total radiative forcing (that is, carbon emissions and other greenhouse gases) is stabilized shortly after 2100 at current target levels (Smith and Wigley, 2006; Clarke and others, 2007; Wise and others, 2009). For the RCP 8.5 scenario, it was assumed that greenhouse gas emissions continue over time leading to relatively high greenhouse gas concentrations in the atmosphere (Riahi and others, 2007). In this report, the RCP 4.5 scenario (representing a low emissions scenario) is comparable to the previous Coupled Model Intercomparison Project phase 3 (CMIP3; U.S. Department of Energy, Lawrence Livermore National Laboratory, 2006), the IPCC special report on emissions scenario (SRES) B1 (Nakićenović and Swart, 2000), and the RCP 8.5 scenario (representing a high emission scenario) is comparable, but with somewhat higher emissions, to SRES A2 used by Bjerklie and others (2015).

The time frame for the projections includes two 20-year periods in the 21 st century, from 2046 to 2065 and from 2081 to 2100 . These are referred to as midcentury and end-ofcentury periods, respectively. As previously stated, the PRMS model simulates hydrologic variables for a current reference period spanning the 20 years from 1981 to 2000 . The 20 -year periods were chosen to provide an adequate length of time to derive mean statistics but a short enough length of time so that the differences between periods are easily discerned from the means and standard deviations. All the GCMs selected were tested for their ability to simulate the sample statistics of weather and hydrologic variables using monthly water balances (LaFontaine and Hay, 2013; LaFontaine and others, 2013; Lauren Hay, USGS, written comm., 2016).

\section{Precipitation Runoff Modeling System}

The PRMS is a USGS public access watershed runoff model (Leavesley and others, 1983; Markstrom and others, 2015) that has been updated by several versions (U.S. Geological Survey, 2017a). The most recent available

Table 1. General circulation models used for climate change scenarios in New Hampshire.

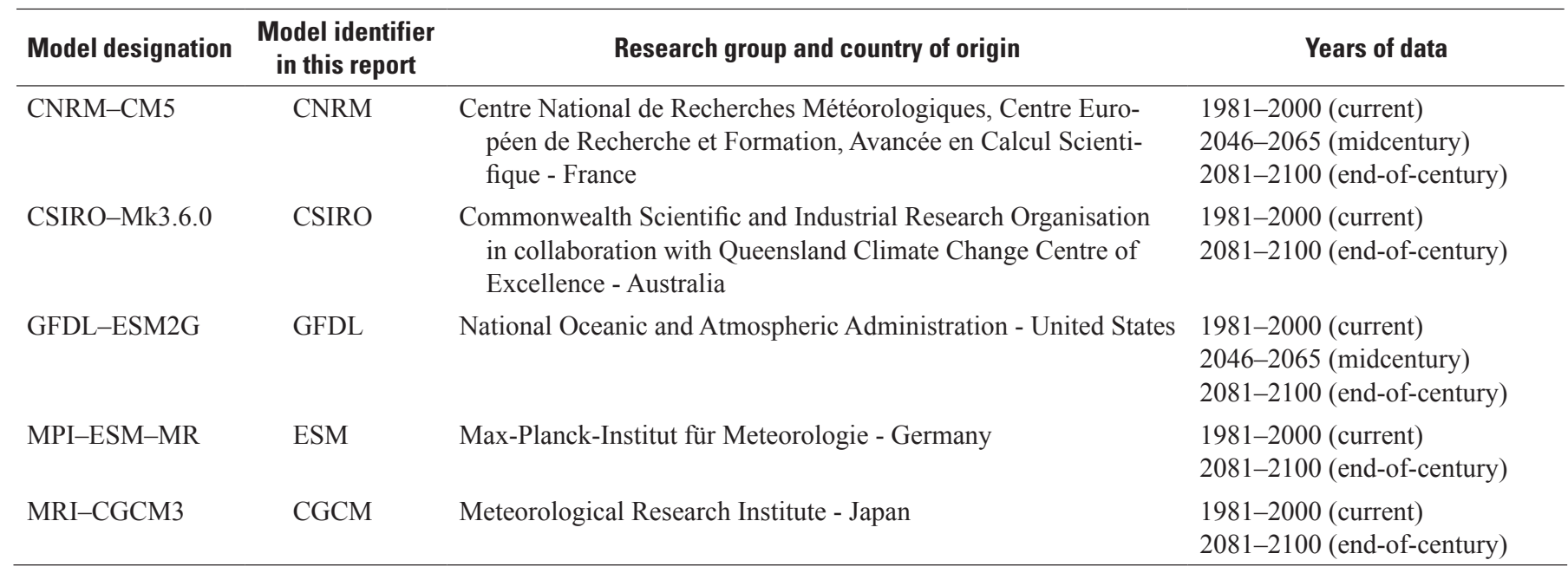


Simulated Hydrologic Response to Climate Change During the 21st Century in New Hampshire

model structure was used for this study (version 4.0, 2015). The PRMS simulates the hydrologic cycle using the spatial variation in measurable physical characteristics, including land cover, topography, soil, and geology, that can be quantified using a GIS. The data and an automated method developed by the USGS (Viger, 2014; Viger and Bock, 2014) were used to develop the model spatial domain and to derive many of the parameters used in the model. Data derived from the National Land Cover Data (NLCD; Vogelmann and others, 2001) were used to set many of the initial parameter values.

The modeled region is divided into subwatersheds, or HRUs. The daily water balance is simulated for each of the HRUs on the basis of precipitation and temperature input data. The HRUs and the 12-digit hydrologic unit code (HUC) subwatersheds (Seaber and others, 1994), although approximately the same scale, are not the same. The HRUs in the PRMS model include a wider range of sizes and could divide some HUC-12s into smaller subwatersheds. In some cases, more than one HUC was aggregated. Although PRMS does not require HRUs to be delineated along watershed boundaries, the HRUs in the model developed in this study represent subwatersheds so that each HRU can represent a streamflow at the HRU outlet.

The total runoff simulated by PRMS is aggregated from the HRUs draining to stream segments that represent the stream channel network in New Hampshire. Each stream segment defined in PRMS represents a channel reach bounded on each side by an HRU and, with the exception of the most upstream segment, is fed by an upstream segment and the two bounding HRUs. The accumulated discharge in the segment is then routed to the next downstream segment using a Muskingum routing scheme (Markstrom and others, 2015).

\section{Justification and Model Applicability}

The PRMS model uses physically based algorithms to simulate various hydrologic processes (Markstrom and others, 2015). The procedure employed in this study first calibrates the coefficients of the PET to match the annual water balance (Bjerklie and others, 2010a, b), then varies the value of various routing coefficients and rain/snow temperature threshold to match the magnitude and timing of streamflow records at USGS streamgages. The method of assigning values to the routing coefficients consists of an algorithm that is tied to measured physical characteristics of the geospatial domain. With this strategy, model uncertainty is limited to the accuracy of the input data, how well the process algorithms represent the various hydrologic pathways, and the effects of spatial scaling. Uncertainty of the model is understood from the calibration statistics and is then assumed to apply to future conditions. This assumption is valid for the various algorithms that are physically based and not subject to changing parameter values that would be associated with climate changemeaning those parameters that are arbitrarily calibrated to a particular set of climatic characteristics.
Three processes are represented in the model that may be altered for the future climate; these are (1) the temperature lapse rate, which is important in the snowmelt simulation; (2) the relation between the occurrence of precipitation and assumed cloudiness, which the model incorporates to estimate incident solar radiation; and (3) the assumed relation between the daily maximum and minimum air temperatures and the vapor pressure gradient. The latter two processes are critical to the estimation of PET.

The lapse rate of temperature with elevation is an important driver for both snow accumulation and snowmelt in HRUs with high topographic relief. Although the dry adiabatic lapse rate would not be expected to change in a changing climate because it is a function of the specific heat of dry air (Wallace and Hobbs, 1977), the lapse rate of moist air varies as a function of relative humidity (Wallace and Hobbs, 1977) and as such will be affected by changes in atmospheric moisture resulting from climate change, generally decreasing with increasing moisture. The decrease in lapse rate would result in more uniform accumulation and melting of snow as a function of elevation. However, the actual lapse rate may vary considerably because of local variations in topography and humidity not captured by the GCM input data or at the HRU scale of the PRMS model; the greatest potential for variation during the snowmelt phase is because of the potential for greater variation in humidity during periods of no precipitation. On a monthly or seasonal time frame, we would expect that local variations in lapse rate, spatially and temporally, would average out and reflect the mean temperature input to the model in a consistent manner across the modeled region. Thus, the relative change in snow accumulation and melt between simulations of current and future climate conditions would be expected to be comparable on the HRU scale and on longer time frames under the assumption that changes in humidity would not alter the monthly and seasonal balance between snowfall and snowmelt. Consequently, we do not place confidence in the simulated timing and magnitude of the daily snowfall and snowmelt and report only monthly snowfall amounts in order to avoid the inherent complexities associated with smaller spatial and temporal scales, particularly with regard to the snowmelt process.

The model simulation of PET is critical to the annual, seasonal, and monthly daily water balance outcomes; therefore, the potential effects of the cloudiness and vapor pressure gradient assumptions are critical to assessing the application of the calibrated model to future conditions. It is assumed that cloudiness associated with precipitation events and incident solar radiation will not change. Thus, the model calibration for the baseline conditions is expected to be applicable to future conditions, and the calibrated model, in this regard, should perform similarly for future conditions as for baseline conditions.

With respect to the assumption that the relation between daily air temperature range and the vapor pressure gradient will remain constant for the current baseline and future conditions, a detailed analysis of the physical process of PET 
and its relation to atmospheric variables is provided in the appendix, along with a comparison of model representations of PET and sensitivity of the PET estimates to temperature change. On the basis of the analysis presented in the appendix, PET is expected to show only minor effects (less than 10 percent) from changes in temperature over the expected range of climate change in the 21st century. Thus, on the basis of the analysis, in humid regions that are expected to remain humid during the next 100 years (2000-2100), as in the northeastern United States, we expect that the assumption remains valid; therefore, the calibrated model can be used to represent future conditions with changed air temperatures.

\section{PRMS Parameterization}

The New England regional PRMS model was initially parameterized using general GIS-based strategies (Steve Markstrom and Lauren Hay, USGS, written commun., 2013) and provided the starting point for the parameterization of the New Hampshire model (Bjerklie and others, 2015). Bjerklie and others $(2010 \mathrm{a}, \mathrm{b})$ determined several other parameters pertaining to groundwater fluxes that were based on surficial geologic characteristics of several watersheds in Connecticut. These methods have been applied in New Hampshire for the model developed in this study.

The PRMS model used for this study was parameterized at the approximate HUC-12 scale using methods that compute parameter values from GIS data or set default values within a range defined by physical limits (Markstrom and others, 2015). The GIS characteristics of each HRU are used to derive initial model parameters. Most of these parameters are not subject to calibration and represent physical properties that determine the parameter value. These GIS characteristics are obtained from national datasets that are used to derive spatial information about the HRU including the coordinates of the HRU centroid, topography (slope, aspect, and elevation; U.S. Geological Survey, 2008a), soils (U.S. Department of Agriculture, 2008), land cover (Vogelmann and others, 2001; U.S. Geological Survey, 2008c), and hydrography (U.S. Geological Survey, 2008b). Snow parameters are primarily derived from an analysis of the temperature input data, which controls when all snow, mixed rain and snow, and all rain occur. These parameters were globally adjusted for all HRUs in the model to attain an optimal representation for snow accumulation across the State.

\section{Climate Data}

The PRMS model uses daily precipitation accumulation and maximum and minimum daily air temperatures as input. The daily precipitation and air temperature data used for this model were obtained through the USGS Geo Data Portal (U.S. Geological Survey, undated) for a 20 -year calibration period (1981-2000) and for future climate datasets consisting of 20-year periods (2046-2065, 2081-2100). The 20-year calibration and the 20-year simulation periods provide sufficient length of time series data to yield representative mean values and variability so that inferential statistics are meaningful and are of sufficient length for comparison with regional projections of atmospheric climate change studies (Wake and others, 2014a,b), as well as other regional climate change projects (U.S. Geological Survey, 2016).

The input time series of daily precipitation and minimum and maximum temperatures used to calibrate the model was derived by Maurer and others (2002; referred to as "the Maurer dataset") and was obtained through the USGS Geo Data Portal (U.S. Geological Survey, undated). The Maurer dataset consists of a gridded product available on a daily time step at the 0.125 -degree $\left(^{\circ}\right)$ spatial resolution (approximately 7.46 miles [mi] or 12 kilometers [km]) for historical periods of record for the continental United States (1949-2010). The Maurer dataset includes daily precipitation and maximum and minimum air temperatures. The data are modeled from streamgage data using physical algorithms to distribute the streamgage data to the $0.125^{\circ}$ grid spacing. These data provide a consistent input dataset, although smoothing of streamgage data over the grid could result in damping of extreme and more intense precipitation events. The Maurer dataset also provides the basis for statistically downscaling the future GCM input data. The Maurer dataset was used to correct bias and to downscale the GCM input from large $1^{\circ}$ grids in the GCM to the $0.125^{\circ}$ grid and then to the HRU through the Geo Data Portal (U.S. Geological Survey, undated).

The future climate datasets were also obtained through the Geo Data Portal and are derived from downscaled GCM simulation data that are stored there, as previously discussed. Previous studies of climate change in New Hampshire (Wake and others, 2014a,b; Bjerklie and others, 2015) used data from the CMIP3 (U.S. Department of Energy, Lawrence Livermore National Laboratory, 2006) set of experiments with associated SRESs (Nakićenović and Swart, 2000). In 2015, Climate Model Intercomparison Project phase 5 (CMIP5; U.S. Department of Energy, Lawrence Livermore National Laboratory, 2011) experimental data that employ revised emission scenarios of the RCPs became available. This study uses the updated CMIP5 RCP simulations. The Geo Data Portal hosts 13 different climate change model datasets for three different climate change scenarios. For this study, five GCM datasets were chosen to represent the possible range of future outcomes. The GCMs that were chosen are listed in table 1 . All five of the GCMs used in this study have been shown to provide water balance results for New England that are statistically comparable to those generated using the Maurer dataset for 1950 to 2000 (Hay and others, 2014; Lauren Hay, USGS, written comm., 2016); the GCMs are considered appropriate for use in New England (Intergovernmental Panel on Climate Change, 2007).

All the GCM projections show substantial temperature and precipitation increases during the 21 st century for watersheds in New Hampshire. Compatible datasets for the current (1981-2000) period and two future (2046-65 and 2081-2100) 
periods were derived for all GCMs. These time frames represent average climate conditions projected to occur for each 20-year climate period. Two RCPs were chosen for each of the two periods (four datasets). One RCP incorporates the assumption of greater reductions in future greenhouse gas emissions (RCP 4.5) than the other RCP (RCP 8.5). RCP 4.5 and RCP 8.5 are comparable to SRES B1 and SRES A2, respectively, used in previous studies in New Hampshire (Bjerklie and others, 2015); the RCP 8.5 is somewhat less optimistic than SRES A2. The RCP scenarios 4.5 and 8.5 provide the upper and lower reasonable bounds of possible climate changes in New Hampshire for the 21st century. The smallest projected changes in precipitation and temperature are associated with the RCP 4.5, and the largest projected changes and the largest uncertainties are associated with RCP 8.5. In general, the largest variability and uncertainty in the GCM projections are for precipitation. The future GCM input datasets represent one specific climate realization and, therefore, may not represent the "expected" future conditions, but rather one equally possible condition. It is anticipated that the hydrologic simulations are primarily driven by the input data from the GCMs and will reflect the specific climate realization that the GCMs provide. In lieu of multiple realizations, we looked for consistency between the five GCMs to provide a level of confidence in the direction (increasing or decreasing) and spatial variability of future change.

The three periods of downscaled data (1981-2000, 2046-2065, and 2081-2100, representing the current, midcentury, and the end-of-century conditions, respectively) were used to calculate the difference between the simulated current and future conditions under each of the two carbon emission scenarios. The changes in daily precipitation and maximum and minimum air temperatures associated with each HRU in the PRMS model and each GCM and scenario show ranges similar to those reported by Bjerklie and others (2010b), Wake (2014a,b), and Bjerklie and others (2015) for the midcentury and end-of-century periods.

\section{Streamflow Data}

USGS streamflow records were used for model calibration (U.S. Geological Survey, 2017b). The PRMS model does not account for storage in lakes and reservoirs and the effects of dams and water diversions; therefore, streamgages used for calibration were selected so that the effects of flow regulation by dams and diversions and storage effects from lakes were not important in streamflow characteristics. The calibration points consisted of 27 streamgages in New Hampshire (fig. 1). The parameters that were selected for calibration are shown on table 2. These were selected for calibration on the basis of the above criteria and had at least 5 years of record during the calibration period (1981-2000).

\section{Modeling Considerations and Calibration Objectives}

This study compared possible future hydrologic changes for various climate change scenarios in New Hampshire. The scenarios were generated using different GCMs and different carbon emission projections. Hydrologic effects of climate scenarios were simulated by use of the self-consistent regional hydrologic model for New England, including New Hampshire, regional PRMS model. Hydrologic self-consistency such that all parameters are calibrated in the same way for all areas of the state and each model run (thus avoiding local differences in calibration that might weight certain processes more than others depending on the input data) is critical for enabling direct comparisons between the different scenarios in time and space. If different models were used or the model was calibrated using methods that are not consistent between different watersheds and for different locations, the model responses to future scenarios would not be directly comparable.

As mentioned previously, historical climate data (Maurer and others, 2002) were obtained from the USGS Geo Data Portal. The data were interpolated from streamgage data by using physically based algorithms to a grid spacing of approximately $7.46 \mathrm{mi}(12 \mathrm{~km})$ and are consistent with other national gridded weather datasets, including the Daymet dataset, which is a gridded daily weather dataset for the continental United States (Oak Ridge National Laboratory, undated), as evidenced by similar calibration results. Daymet input data were used in the New Hampshire PRMS pilot study (Bjerklie and others, 2015). Interpolation can cause smoothing of the data such that the timing and magnitude of local events are inaccurate; however, long-term averages are accurate (Thornton and others, 1997; Stahl and others, 2006; Oubeidillah and others, 2013; Di Vittoria and Miller, 2014). The future climate input data derived from GCMs are statistically downscaled from larger grids, and the issues of smoothing and a loss of detail resulting from the resolution of the GCM data are likely to be inherent in future simulations.

Data and calibration consistency are key to the regional model development so that spatial comparisons can be made without differences in calibration and input that would complicate the comparison. The objective functions for the PRMS calibration consist of streamflow statistics measured at USGS streamgages, streamflow hydrograph characteristics, and the annual and seasonal water balance. To avoid the potential for variable and (or) exaggerated response to future input datasets between HRUs, the following modeling and calibration objectives were adopted for this study.

- Use of regionally distributed input datasets for calibration and for future comparisons. The input datasets are derived from nationally consistent sources and developed using consistent methods. The same GCMs used to derive future scenario input datasets are used to derive the current scenario input climate datasets so that comparisons are not confounded by inherent data biases. 
Table 2. Calibrated parameters for the Precipitation Runoff Modeling System.

[Parameter calibrations based on defined physical relations that can be applied in any hydrologic response unit (HRU) using a geographic information system (GIS). Elevation datum is National Geodetic Vertical Datum of 1929]

\begin{tabular}{|c|c|c|}
\hline Parameter & Function & Calibration method \\
\hline \multicolumn{3}{|c|}{ Water balance } \\
\hline jh_coef & Controls monthly variation in potential evaporation demand & $\begin{array}{l}\text { Adjusted based on calibration method in Bjerklie and others } \\
\text { (2010b) }\end{array}$ \\
\hline jh_coef_hru & $\begin{array}{l}\text { Controls spatial variation in potential evaporation demand } \\
\text { as a function of HRU elevation and latitude }\end{array}$ & $\begin{array}{l}\text { Adjusted based on calibration method in Bjerklie and others } \\
(2010 \mathrm{~b}) \text { and physical characteristics of the HRU }\end{array}$ \\
\hline \multicolumn{3}{|c|}{ Storage and routing of water through the watershed } \\
\hline fastcoef_lin & $\begin{array}{l}\text { Controls daily outflow from the upper part of the subsurface } \\
\text { (between the spoil and the saturated groundwater) reser- } \\
\text { voir associated with each HRU }\end{array}$ & $\begin{array}{l}\text { Varies as a function of the amount of coarse stratified drift } \\
\text { in the HRU, parameters set by trial and error }\end{array}$ \\
\hline slowcoef_lin & $\begin{array}{l}\text { Controls daily outflow from the lower part of the subsurface } \\
\text { (between the spoil and the saturated groundwater) reser- } \\
\text { voir associated with each HRU }\end{array}$ & $\begin{array}{l}\text { Set as one half of the value of the fastcoef_lin, in lieu of no } \\
\text { specific information available to define its value in rela- } \\
\text { tion to G. Other fractions were tested and found to have } \\
\text { minimal effect on calibration }\end{array}$ \\
\hline carea_max & $\begin{array}{l}\text { Maximum area of variable saturated source in an HRU that } \\
\text { can contribute directly to water bodies }\end{array}$ & $\begin{array}{l}\text { Varies as a function of the soil type and the amount of } \\
\text { depression storage in the HRU }\end{array}$ \\
\hline soil2gw_max & $\begin{array}{l}\text { Controls the amount of infiltrated water percolating directly } \\
\text { to the saturated groundwater from the soil layer, bypass- } \\
\text { ing the subsurface zone }\end{array}$ & $\begin{array}{l}\text { Varies as a function of the amount of coarse stratified drift } \\
\text { in the HRU }\end{array}$ \\
\hline \multicolumn{3}{|c|}{ Snow accumulation and storage } \\
\hline tmax_allrain & $\begin{array}{l}\text { Temperature at which precipitation is considered all rain, } \\
\text { with no snow accumulation }\end{array}$ & Adjusted by trial and error \\
\hline
\end{tabular}

- Use of consistent methods to assign parameter values for all regions in the model.

- Parameterization of the model with methods based on physical features of watersheds. Parameters that cannot be assigned a value from data are left as default values that represent a typical condition to ensure that the values are consistent across the State.

- Calibration objectives include water balances and comparison of streamflow statistics at calibration streamgages.

The primary objective function includes goodness of fit as measured with the Nash-Sutcliffe efficiency (NSE) statistic, which weighs the timing and magnitude of the time series of simulated streamflow estimates (Nash and Sutcliffe, 1970; Moriasi and others, 2007). The NSE is used to compare the difference between the paired measured and simulated streamflows with the corresponding difference between the measured and the mean of the measured streamflows (see Bjerklie and others, 2015). Additionally, the residual variance (difference between measured and simulated) is compared with the variance of the measured values from its own mean, thus providing a measure of how well the simulated values fit the observations relative to a constant mean value. Following Moriasi and others (2007), an NSE of 0.5 or greater is considered a satisfactory or good fit between the simulated and measured hydrographs, and an NSE of 0.4 to 0.5 is considered marginally satisfactory. Values of NSE less than 0.4 are considered unsatisfactory.

Additional measures of goodness of fit, addressing systematic error (bias) and comparability of overall sample variability include the percent bias (PBIAS; Moriasi and others, 2007), the log residual of error between the simulated and measured daily streamflows, the ratio of the root mean square error to the standard deviation (RSR; Moriasi and others, 2007), and the normalized root mean square error (NRMSE) expressed as a percent. The NRMSE represents the sample standard deviation of the differences between simulated values and measured values (Hyndman and Koehler, 2006) and aggregates the magnitudes of the errors between the paired simulated and measured streamflows in the time series into a single measure of predictive power. The NRMSE is thus a measure of overall accuracy. Normalizing the root mean square error (RMSE) facilitates the comparison of streamflow 
estimates at streamgage locations with different scales. The RMSE is normalized in this study on the full range of measured streamflow values, computed as the square root of the summed squared differences between the paired measured streamflow divided by the number of paired values and normalized (divided) by the difference between the maximum measured value and the minimum measured value.

\section{Calibration of the New Hampshire PRMS Model}

The model was calibrated to measured USGS streamgage records at the regional scale for the period 1981 to 2000. To achieve the best fit water balance for each HRU, the PET simulated by the model was optimized by comparing the long-term simulated streamflow against the long-term measured streamflow at the 27 USGS streamgages. This approach derives coefficients directly from the temperature records and HRU elevation (Markstrom and others, 2015). The primary objective of the large area (statewide) calibration was to provide a reasonable representation of the annual water balance, with local variability in streamflow in individual rivers, on the whole, being within acceptable calibration standards for daily and monthly streamflows.

The PRMS model simulates unregulated natural streamflow and, as applied in this study, does not simulate the effects of dams, lake and reservoir storage, and groundwater and surface-water diversions; therefore, these were not considered in the calibration. A method to adjust the monthly evapotranspiration coefficient in the model developed by Bjerklie and others (2010a) was used to calibrate the model-simulated evapotranspiration and general water balance for New Hampshire HRUs. Other parameters that affect snow, snowmelt, and interception were adjusted to be comparable to Bjerklie and others (2010a) or were kept at their GIS derived values. The groundwater base-flow coefficient, which controls the rate of outflow from the groundwater reservoir associated with each HRU, was estimated using a method that predicts the value from the land cover and hydrologic characteristics of each HRU (R.J. Viger, USGS, written commun., 2016). The default values for the subsurface routing coefficients, which represent the interflow component of groundwater runoff, were not adjusted in the model because there was insufficient regional information to assign values on the basis of the GIS data. The subsurface runoff coefficient affects groundwater recharge and the shape of the hydrograph recession (see calibrated parameter list; table 2).

The routing coefficients used in the model are linear functions, and the model would be expected to respond similarly to different input data of similar range. The current and future input datasets used for the simulations generally show a shift in the mean, maximum, and minimum values in the same direction without a large change in the range of the data. Simulation errors (difference between the USGS streamflow data and the simulated streamflows) for the calibrated model, therefore, will be consistently carried over to future time frames, and the magnitude and frequency of changes between simulated current and future conditions will be a product of the differences in the input datasets and the physical constraints of the modeled hydrologic system, and will not be arbitrary.

New Hampshire exhibits a strong temperature gradient with latitude. The default PET coefficients were adjusted to account for this by uniquely fitting each coefficient to each HRU. The coefficient was adjusted up or down by a factor constant for all HRUs to match the long-term water balance so that precipitation minus actual evapotranspiration equaled the mean annual streamflow (total runoff) for the calibration period (1981-2000) at the 27 streamgages. It was assumed that matching the long-term mean does not seriously bias the daily and seasonal water balance estimates.

\section{Evaluation of the New Hampshire PRMS Model}

The calibrated model simulations are evaluated by statistically comparing the population of simulated streamflows and the USGS measured streamflow. The results are evaluated with the NSE statistic, the PBIAS, the RSR, the NRMSE expressed as a percent, and the log residual of the simulated minus the measured streamflow. The mean and standard deviation of the $\log$ residual reduce the weight (influence) of the low end and high end errors, providing a better picture of the typical residual error of the time series when the daily and monthly residual errors are averaged. The log residual, the PBIAS, the NRMSE, and the RSR all characterize the overall error and bias in the simulated hydrographs compared to the measured hydrographs. The NSE statistic is a measure of how well a simulated dynamic time series (streamflow hydrograph) fits the measured time series during the period of record relative to the mean, accounting for timing and quantity. A value of 1 for the NSE indicates that the simulated and measured time series are identical, and a value of 0 indicates that the simulated time series provides as much predictive information as the mean of the measured time series alone. Negative values for NSE indicate that the model simulation provides less predictive information than the mean value.

The PRMS model calibration was evaluated on the daily time step, and the aggregated monthly and annual time steps, by comparing the simulated streamflows with measured streamflows at USGS streamgages in the State. The New Hampshire model showed very good simulation of the mean streamflow at all the streamgages after the statewide calibration (fig. 2; table 3). The error for the mean annual simulated daily streamflows for the 27 streamgages is 6 percent with an absolute error of $0.15 \mathrm{in}$. of runoff per unit area of watershed, which indicates that the regional annual water balance, on average, is well simulated. The error in the mean of the standard deviation of the simulated daily streamflows is -4 percent with an absolute error of -0.13 in. of runoff per unit area of 
$\boldsymbol{A}$

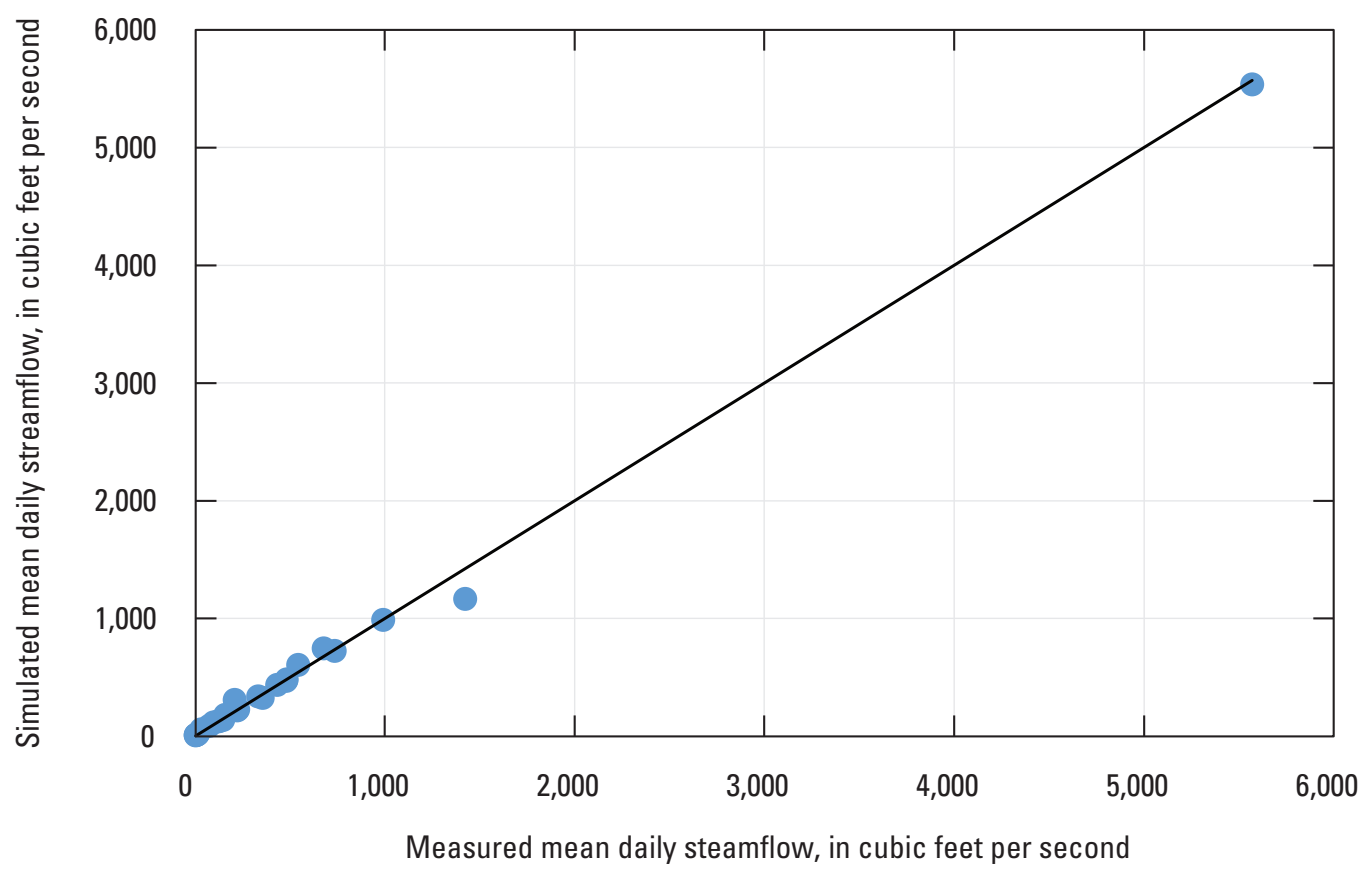

B

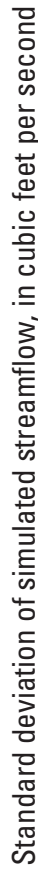

6,00

5,000

5,000

4,000

3,000

3,000

2,000

1,000

0

,

Standard deviation of measured mean daily streamflow, in cubic feet per second

Figure 2. A, Simulated mean daily streamflow in relation to measured mean daily streamflow and $B$, standard deviation of simulated streamflow in relation to the standard deviation of measured mean daily streamflow at 27 calibration streamgages in New Hampshire for the period of record for each streamgage. 
watershed, which indicates that the variation in mean streamflows around the State was also well simulated. The mean percent differences and ranges of differences in this study are similar to the differences found in other calibrated PRMS models developed for complex terrain where the data were used to assess hydrologic change and to represent hydrologic conditions when comparative data were not available (Koczot, 2005; Chase, 2011). The simulated monthly mean streamflows for the period of record for all the calibration streamgages plotted in relation to the measured monthly mean streamflows are shown in figure 3.

Table 3. Description of 27 selected streamgages with streamflow calibration statistics in New Hampshire.

[This table is available for download at https://doi.org/10.3133/sir20175143]

The 27 streamgages used for the evaluation are described, and the associated calibration statistics on the daily and monthly time steps for each gage are listed, in table 3. An NSE statistic of 0.5 or larger indicates a satisfactory or "good" calibration; 0.4 to less than 0.5 , a marginal or "fair" calibration; and less than 0.4 , a relatively "poor" calibration (Moriasi and others, 2007). For this study, a mean log residual less than 0.1 (overall error of approximately 10 percent or less) is considered a good (satisfactory) calibration; greater than 0.1 and less than or equal to 0.2 , fair (marginal); and greater than 0.2 , poor. Also in this study, an NRMSE of greater than 10 percent is considered unsatisfactory. According to Moriasi and others (2007), a PBIAS greater than 20 percent and an RSR greater than 0.7 are considered to represent a fair or poor simulation.

The daily calibration statistics show that 14 of the 27 streamgages have good calibration on the basis of the NSE statistic, 5 have a fair calibration, and 8 have a poor calibration. The RSR statistic is similar to the NSE statistic, with 13 streamgages having a satisfactory simulation (13 included in the 14 with satisfactory NSE). The NRMSE statistics show that 26 of 27 streamgages have an overall error of 10 percent or less. The mean log residual of the daily estimates shows that 19 of the streamgages have an error less than or equal to \pm 10 percent, and 22 have an error less than or equal to \pm 20 percent, indicating that most of the streamgages have an acceptable calibration. Only two simulations show PBIAS greater than 20 percent. The streamgages that show poor calibration indicate that some aspect of the simulation is not being accurately represented at the daily time step. This could be because of nonrepresentative input data resulting from orographic effects and effects of storage or another physical feature of the HRU that is not represented by the GIS data for the HRUs composing the watershed.

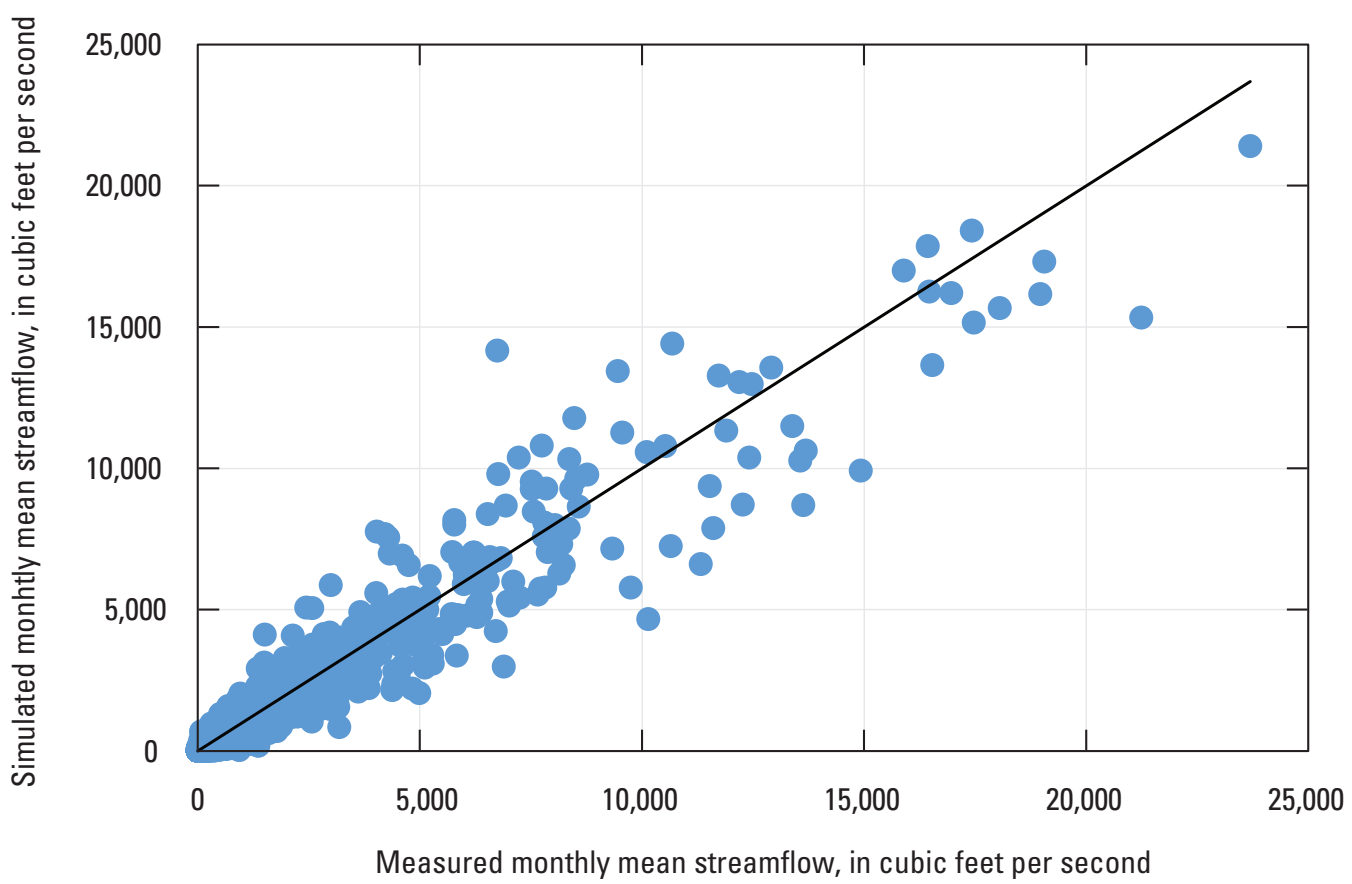

Figure 3. The simulated monthly mean streamflow in relation to the measured monthly mean streamflow at the 27 calibration streamgages in New Hampshire for the period of record at each streamgage. 
The statistics for the distribution of the error across the model are shown on figure 4 . Figure $4 A$ (daily NSE statistic) and $4 B$ (monthly NSE statistic) shows that the poor calibrations occur in the vicinity of the White Mountains, in the extreme north of the State, and in one small coastal basin, the Oyster River (streamgage 1073000), which includes some diversions supplying water to the University of New Hampshire. The poor daily calibration in the White Mountain area may reflect situations where the climate input data are affected by the resolution of that data, particularly in headwater areas and where large parts of the watersheds are in the White Mountains. The 7.45-mi (12-km) grid spacing of the Maurer dataset, as well as the downscaled GCM data, likely do not capture the magnitude of the orographic effects of this mountain terrain (Bjerklie and others, 2015). Additionally, the input data to the PRMS model associated with the simulation at the Big Brook near Pittsburg streamgage (1127880) are likely affected by data limitations resulting from the proximity to Canada. The poor calibration for the Oyster River streamgage in coastal New Hampshire may also be a function of the resolution of the input data near areas of GIS data discontinuity - in this case, the proximity to Canada and the Atlantic Ocean, which do not have the same GIS and weather data grid as New Hampshire.

For the monthly time step, the calibration statistics are much better overall (figs. $4 B$ and $5 B$ ). On the basis of the NSE (fig. $4 B$ ), only five streamgages exhibit poor calibration, and one exhibits fair calibration. All the others (21 streamgages) show good calibration $(>0.5)$. The log residual of the monthly streamflows shows the same geographic pattern, with only three streamgages exhibiting poor calibration $(>0.2$, or approximately 20 percent error (fig. $5 B$ ). Those streamgages with poor monthly calibration are in the extreme north in the White Mountains, locations that are similar to those for streamgages with poor daily calibration statistics. The fact that the monthly calibration is much better than the daily calibration further indicates that the timing of daily precipitation events in the input data may be the most important driver in producing the simulation errors instead of the general water balance.

The range of errors and NSE statistics exhibited are within those documented for monthly mean streamflow in other USGS PRMS studies designed to simulate streamflow in ungaged rivers as part of water resource planning efforts (Chase, 2011) and in PRMS studies designed to simulate streamflow in other regional and local areas (Viger and others,
2010; Dudley and Nielsen, 2011; LaFontaine and Hay, 2013; LaFontaine and others, 2013). However, the errors indicate that the daily streamflows need to be used with more caution than the monthly streamflows, particularly in regions of higher elevations in the State and near the dataset boundary. Given that the general water balance seems to be well simulated for most of the streamgages used in model calibration, the calibration would be most applicable when considering changes in water balance rather than timing of streamflows. Similarly, considering the overall water balance on the monthly time step, groundwater recharge and snow accumulation can be used with reasonable confidence at the HRU spatial scale.

Future simulations using the PRMS model are expected to provide hydrologic responses to the future climate input datasets with similar characteristics for the daily, monthly, and seasonal streamflow variations. The focus of this study is to look at differences between current and future conditions. The future model results were compared only with the current conditions using the same model parameters for each streamgage. Therefore, the comparison of current and future conditions will evaluate change that is based on the same watershed characterization; these comparisons are considered sufficiently valid as long as the water balance is represented well.

Considering all 27 streamgages, there is a weak negative correlation (90-percent confidence interval) between the elevation of the streamgage and the daily NSE statistic, indicating that the streamgages in and around the higher elevations in the White Mountains are subject to the greatest calibration error and, therefore, the greatest uncertainty in interpreting future simulations. There is also a weak negative correlation between the elevation of the streamgage and the daily log residuals with the residual being a larger positive value (overprediction; simulated streamflow greater than measured streamflow) at lower elevations and a larger negative value (underprediction; simulated streamflow less than measured streamflow) at higher elevations. Also, the largest absolute errors indicated by the daily log residuals occurred as underpredictions. These observations indicate that the largest errors are because of underrepresentation of the larger precipitation events in the mountains where orographic effects are important. The daily and monthly patterns of error may result from underprediction of precipitation at higher elevations but also may be driven by the issue at USGS station 01127880 (Big Brook), resulting from incomplete data because of the proximity to the boundary of the climate dataset (which does not extend into Canada). 


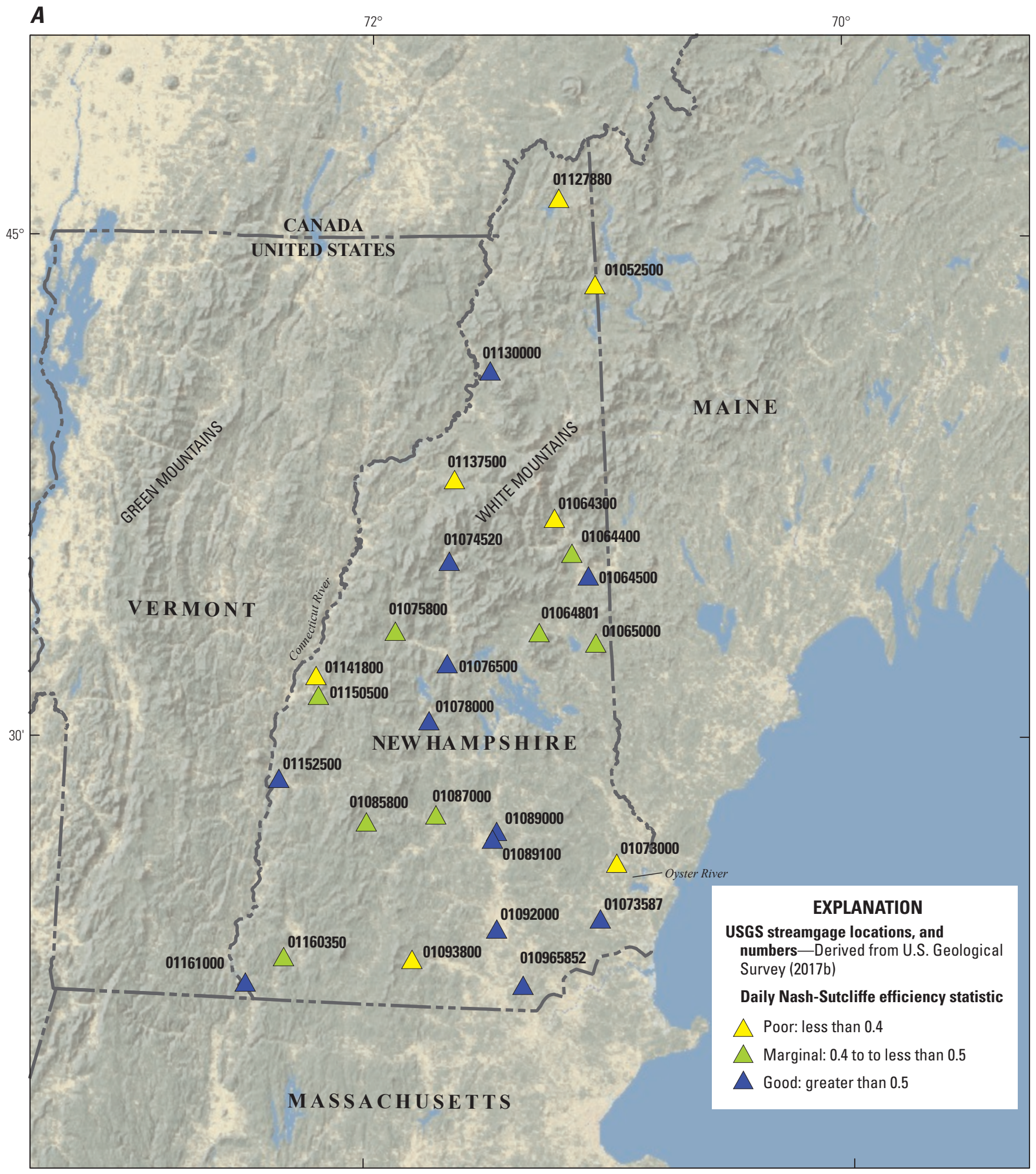

Base from U.S. Geological Survey The National Map digital data Albers equal area conic projection North American Datum 1983

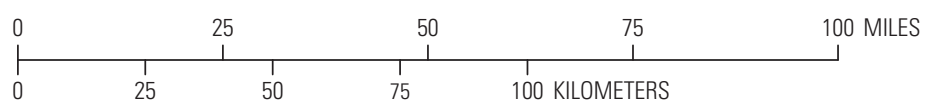

Figure 4. The spatial distribution of Nash-Sutcliffe efficiency statistic for 27 streamgages in New Hampshire at $A$, the daily time step and $B$, the monthly time step. 


\section{B}

$72^{\circ}$

$70^{\circ}$

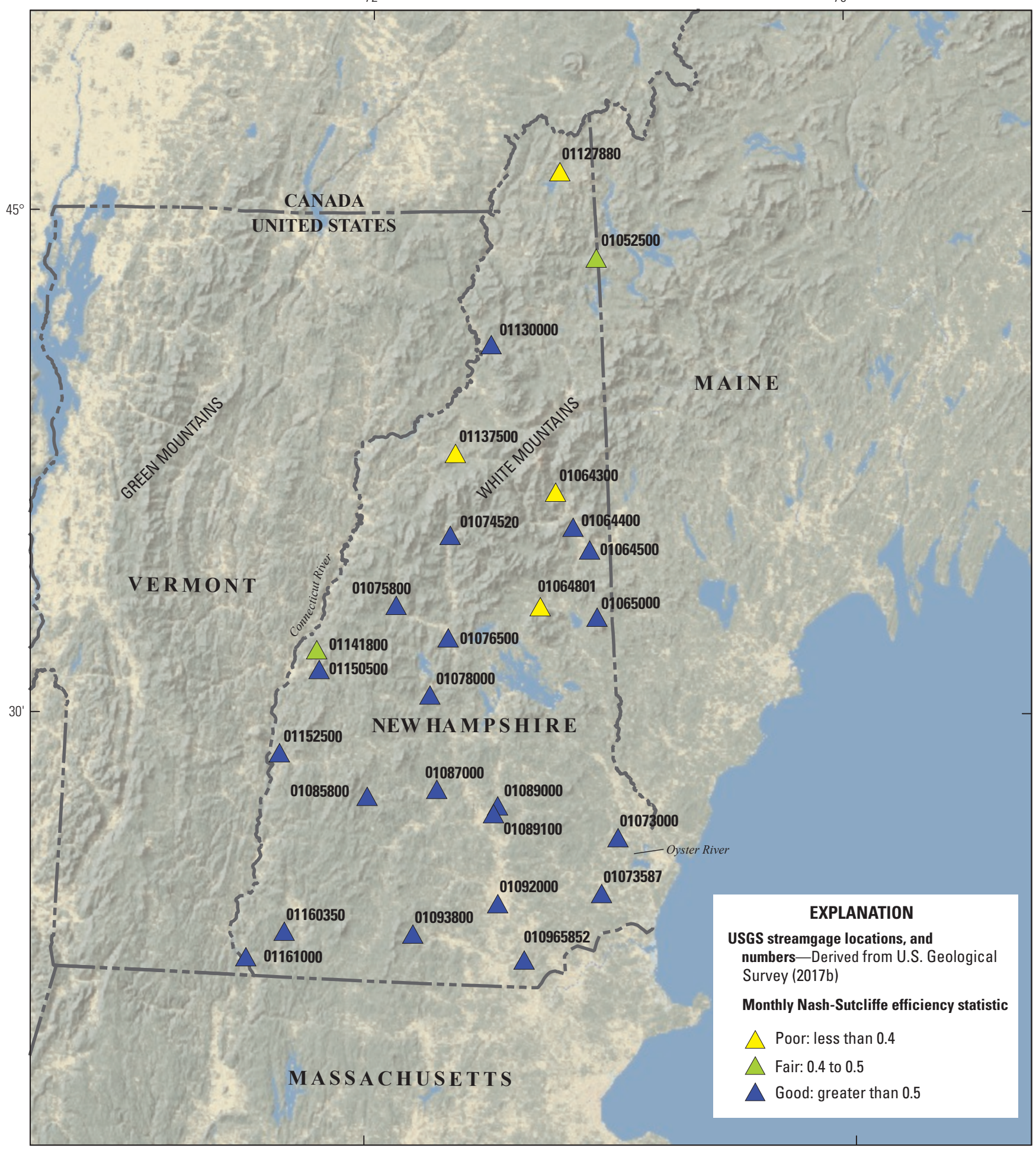

Base from U.S. Geological Survey The National Map digital data Albers equal area conic projection North American Datum 1983

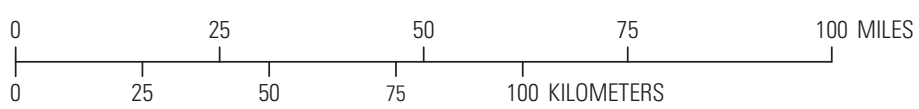

Figure 4. The spatial distribution of Nash-Sutcliffe efficiency statistic for 27 streamgages in New Hampshire at $A$, the daily time step and $B$, the monthly time step.-Continued 


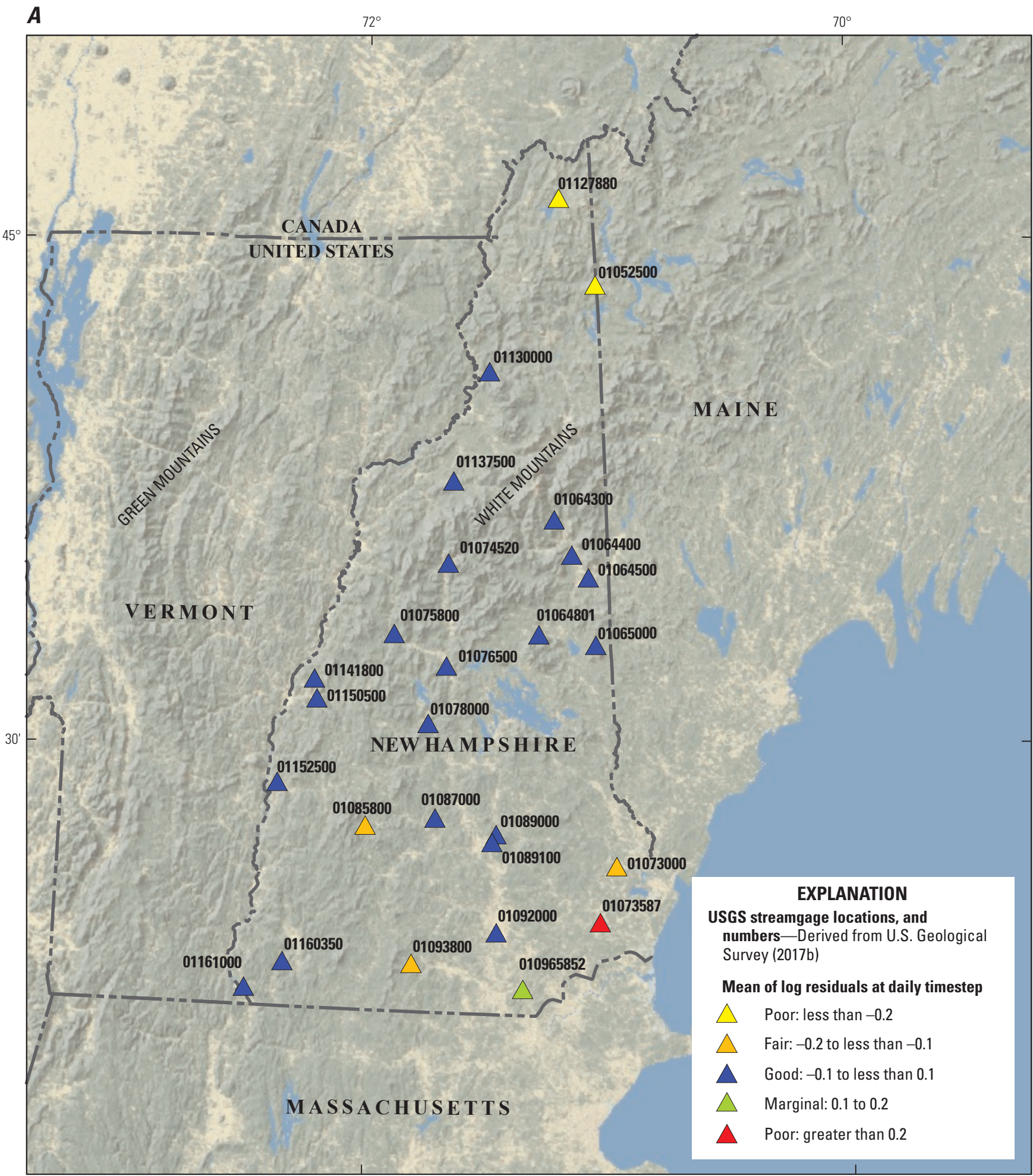

Base from U.S. Geological Survey The National Map digital data Albers equal area conic projection North American Datum 1983

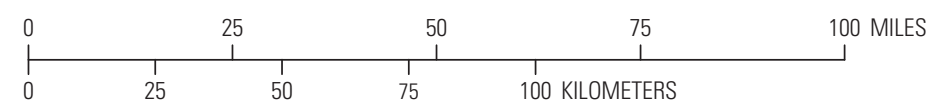

Figure 5. The spatial distribution of the mean of the log residuals for 27 streamgages in New Hampshire at $A$, the daily time step, and $B$, the monthly time step. 


\section{B}

$72^{\circ}$

$70^{\circ}$

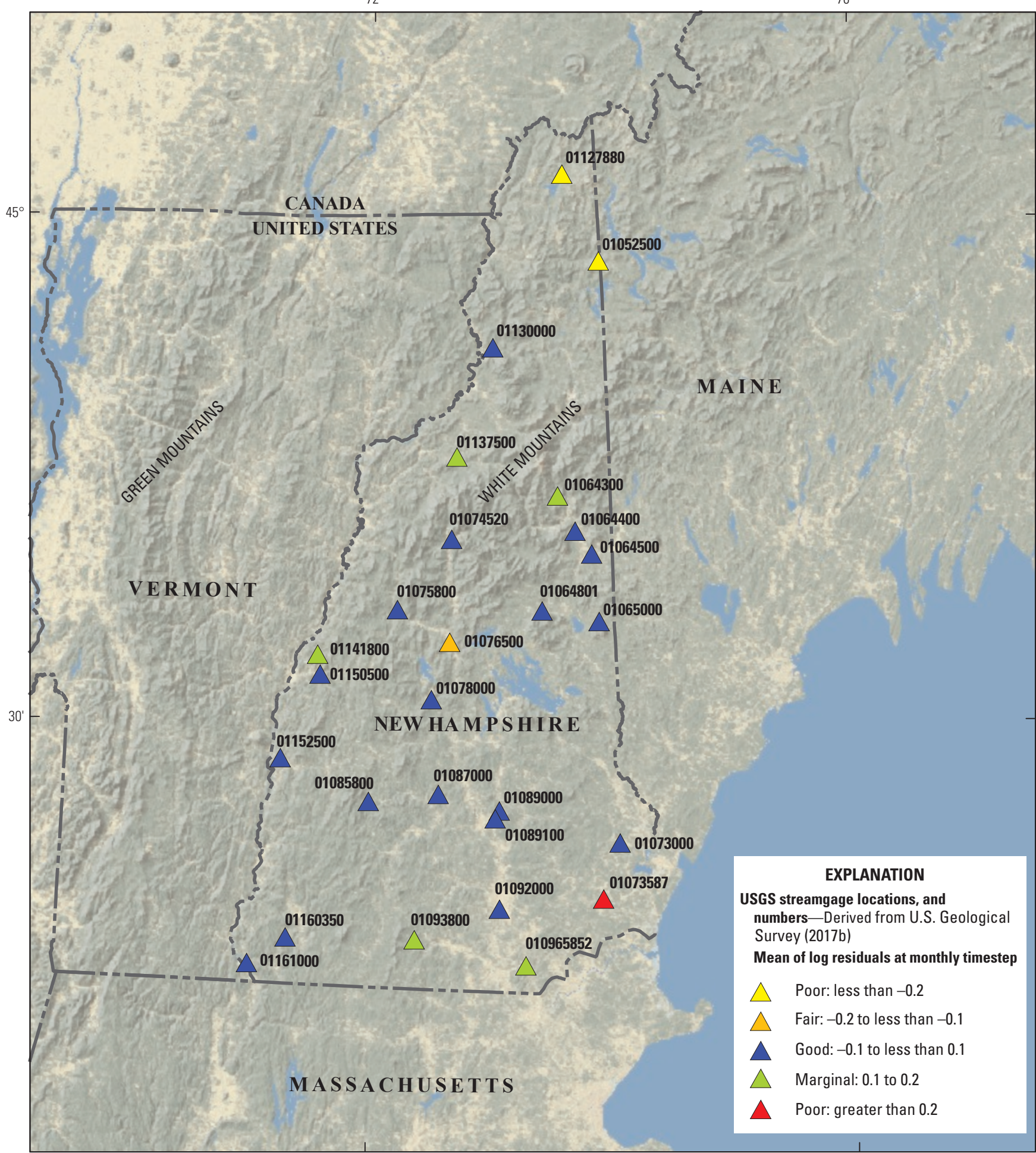

Base from U.S. Geological Survey The National Map digital data Albers equal area conic projection North American Datum 1983

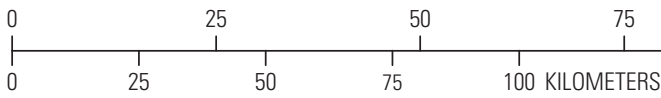

100 MILES

Figure 5. The spatial distribution of the mean of the log residuals for 27 streamgages in New Hampshire at $A$, the daily time step, and $B$, the monthly time step.-Continued 


\section{Simulated Hydrologic Response to Climate Change}

The parameterized and calibrated New Hampshire PRMS model was used to generate simulated daily streamflow values for a 20-year period representing current hydrologic conditions (1981-2000) and two 20-year periods representing future hydrologic conditions (2046-65 and 2081-2100). The five GCMs chosen for this study were used to generate individual 20-year time series of daily streamflow, groundwater recharge, and snowfall for the current period (1981-2000) for each of two climate change scenarios (RCP 4.5 and RCP 8.5). The future time series (four time series for each GCM input, including two scenarios for midcentury and end of century) were compared with the historical time series generated by each GCM to insure self-consistency. The changes that may occur in streamflow, groundwater recharge, and snowfall across the State as a result of climate change were evaluated.

Mean daily streamflow and the standard deviation of daily streamflow (indicating a greater range of flows with more highs and lows) are forecast to generally increase at all 27 streamgages across the State. The mean and standard deviation of the changes in average daily streamflow for the 27 streamgages, in percent, between the future periods and the historical period for both emissions scenarios and all GCMs, and the composite (average) of all five GCMs are listed in table 4. Most streamgages show an increase in the standard deviation of daily streamflows; however, simulations from the GCM designated as CNRM-CM5 from the Centre National de Recherches Météorologiques (CNRM, France; see table 1) are the exception, in general, showing a decrease in the standard deviation of daily streamflows. The general tendency for the GCMs to produce increasingly greater standard deviations of daily streamflows indicates that there will be higher high flows and lower low flows. The patterns of change in mean streamflow are shown in figures $6 A$ and $B$ for both scenarios and two of the GCMs: the coupled general circulation model (CGCM), which is the GCM designated MRI-CGCM3 from Yukimoto and others (2012), and the GFDL model, which is the GCM designated GFDL-ESM2G from the National Oceanic and Aeronautics Administration Geophysical Fluid Dynamics Laboratory (2016) - as examples. The composite mean percentage changes for all five GCMs and both scenarios, by month, are listed in table 5 . The changes in standard deviation of the composited means are listed in table 6 .

Table 4. Simulated mean change in daily streamflow and standard deviation using two emission scenarios and five general circulation models, plus a composite, for 27 streamgages in New Hampshire, by 20 -year periods.

[This table is available for download at https://doi.org/10.3133/sir20175143]
Table 5. Simulated change in mean monthly streamflow, in percent, for 27 selected streamgages in New Hampshire, composited from simulations made from all five general circulation models and two scenarios from 2046 to 2065 and 2081 to 2100 .

[This table is available for download at https://doi.org/10.3133/sir20175143]

Table 6. Standard deviation of the percent change in the mean of the monthly streamflows at 27 selected streamgages in New Hampshire, composited from simulations made from all five general circulation models and two scenarios from 2046 to 2065 and 2081 to 2100 .

[This table is available for download at https://doi.org/10.3133/sir20175143]

By midcentury (2046-2065), all five GCMs show increased mean streamflow for both scenarios by various percentages, except for the streamflows generated by the Earth system model (ESM) with the RCP 8.5 emissions scenario, which shows decreases at most of the streamgages (table 4). Additionally, for a few streamgages, CGCM and CNRM show a decrease. By the end of the century (2081-2100), all the GCMs for both scenarios show increased streamflow, except CNRM RCP 4.5. The seasonal pattern of change in streamflow is relatively consistent for all the GCMs with the largest increases in streamflow occurring in the winter and early spring and the largest decreases in the late spring and summer. The spatial pattern of change is less consistent, varying by GCM, emissions scenario, and time period. However, the largest increases generally occur in the eastern part of the State. The standard deviation of the composited means provides an indication of the uncertainty in GCM projections because the composited mean represents the difference between simulations using the different GCM input data rather than the standard deviation of the simulated streamflow time series from an individual model run.

The daily streamflow data are expected to have an accuracy that is reflected in the calibration. Therefore, those streams with relatively poor NSE values and high log residuals may not be representative of the general hydrologic response at the time step of the time series; hence, the NSE values and $\log$ residuals are not provided for more detailed analysis. Specifically, the nonrepresentativeness includes conditions that control volume and timing at the daily time step, including routing through the groundwater and subsurface reservoirs, routing in the stream channel, storage in the watershed, and snowmelt processes. Smoothing and damping of large precipitation events in the gridded climate data and lack of detail in the model regarding storage and routing effects on daily streamflow restrict the validity of using the daily data to interpret magnitude and timing of floods. However, change in streamflow, based on differences between the GCM input for current and future time periods, can be considered selfconsistent and controlled primarily by the GCM input rather 
than the PRMS calibration. Streamflow on the monthly time step (mean of the daily values for the month) is expected to be more accurate and reflective of the processes that control streamflow at that temporal scale.

The statewide changes in groundwater recharge and snowfall, in percent (tables 7 and 8, respectively), represent the unweighted composited means from the GCM future simulations. The unweighted means are derived by averaging the linear estimates of recharge and snowfall, in inches, for each HRU without adjusting for HRU area. The snowfall is reported as snow-water equivalent times 10 (Bjerklie and others, 2015) to provide a value consistent with a typical snow depth. Table 7 indicates that the largest quantitative variability between models (as evidenced by the standard deviation) was measured in the simulated groundwater recharge using the RCP 4.5 scenario.

Figures 7 and 8 show that there is significant spatial variability in the simulated change in mean groundwater recharge and snowfall across the State. However, the change in groundwater recharge shows relatively consistent patterns of spatial variability between models but with different magnitudes. The simulated changes in groundwater recharge that are based on the RCP 4.5 scenario show decreased recharge in the HRUs adjacent to the Connecticut River with increases in most other parts of New Hampshire, and the simulated changes that are based on the RCP 8.5 show an expansion of areas with decreases. All the models generally simulated decreased groundwater recharge for the end-ofcentury period (2081-2100) for both scenarios. This indicates that by the end of the century, increases in evapotranspiration may outpace summer and fall increases in precipitation.

The mean changes in groundwater recharge over the periods representing current, midcentury, and end-of-century conditions are reflective of the mean water balance, which has been shown to be accurately represented in PRMS. Thus, we anticipate groundwater recharge change estimates to be primarily the result of the input data and not the result of arbitrary variation in infiltration and movement through the subsurface; thus, the estimates reflect the specific climate realizations that the GCMs provide.

Generally, snowfall is projected to decrease through the 21 st century across the State for both RCP scenarios for all months, with one exception. The exception is the CGCM RCP 4.5 simulation, in which March snow first increases by the midcentury (2046-65) period, then decreases by the end-of-century (2081-2100) period (table 8). However, the decreases are not uniform across the State, and in fact, snow is projected to increase in some locations for some months (fig. 8), depending on the GCM and the RCP scenario used. For example, using the CGCM GCM for RCP 4.5, March snow is projected to increase in southern New Hampshire generally by midcentury and continue to increase by the end of the century in several locations in the same part of the State (fig. $8 A, B$ ). Similarly, simulations using the GFDL GCM with RCP 8.5 for November for the midcentury period show some areas of increasing snow in southern New Hampshire (fig. 8C). However, the GFDL simulations for midcentury with RCP 4.5 show increased snow for February in northern New Hampshire (fig. $8 D$ ); for the same GCM, this area of increase is greatly reduced across the northern part of the State during the end-of-century period (fig. $8 E$ ).

The difference between the total winter trends and the monthly trends in snowfall indicate that, even with warming temperatures, snowfall will remain an important feature of winter in New Hampshire, and snowfall is likely to be more variable with the possibility that some months may experience relatively large snowfalls during early and late winter relative to current conditions, particularly in midcentury. Relatively large snowfalls could occur because, for the future climate, the possibility of months with below freezing temperatures still remains (winter is a function of the seasonal variation in the declination of the sun); below freezing temperatures combined with increased atmospheric moisture can result in high snowfall.

Spatial variability in the monthly changes (percent) for increased and decreased snowfall may be significant. The locations of the increases and decreases vary and are likely the result of the particular dynamics associated with each GCM run; if many simulations of snowfall for each GCM were run, it would be possible to derive a statistical probability of the different realizations. Snow generally will decrease but may be highly variable, depending on location, GCM, and climate RCP scenario. The change in snowfall directly reflects changes in the atmospheric inputs to the model via the selected temperature for all snow, rain and snow mix, and all rain thresholds. Consequently, the change in snow amounts would be consistent with the defined parameter values and would also be expected to primarily reflect the input data rather than the PRMS model calibration.

\section{Model Sensitivity to Land-Use Change and Effects Relative to Climate Change}

The sensitivity of the PRMS model to land-use change, as reflected in the percent impervious surface in each HRU, was evaluated in order to compare the relative magnitudes of climate change and land-use change. It was assumed that land-use change resulting from increased development can be directly indexed by increasing impervious surface. In PRMS, increases in the percent impervious surface will uniformly drive decreases in recharge and base flows and increases in peak streamflows, unless storm retention structures are considered. The degree of change would be highly local, depending on the spatial distribution of development; however, assuming reasonable estimates of increased impervious surface uniformly distributed in an HRU, the resulting hydrologic changes could be on par with those predicted over longer time frames as a result of climate change. 
$\boldsymbol{A}$

$72^{\circ}$

$70^{\circ}$

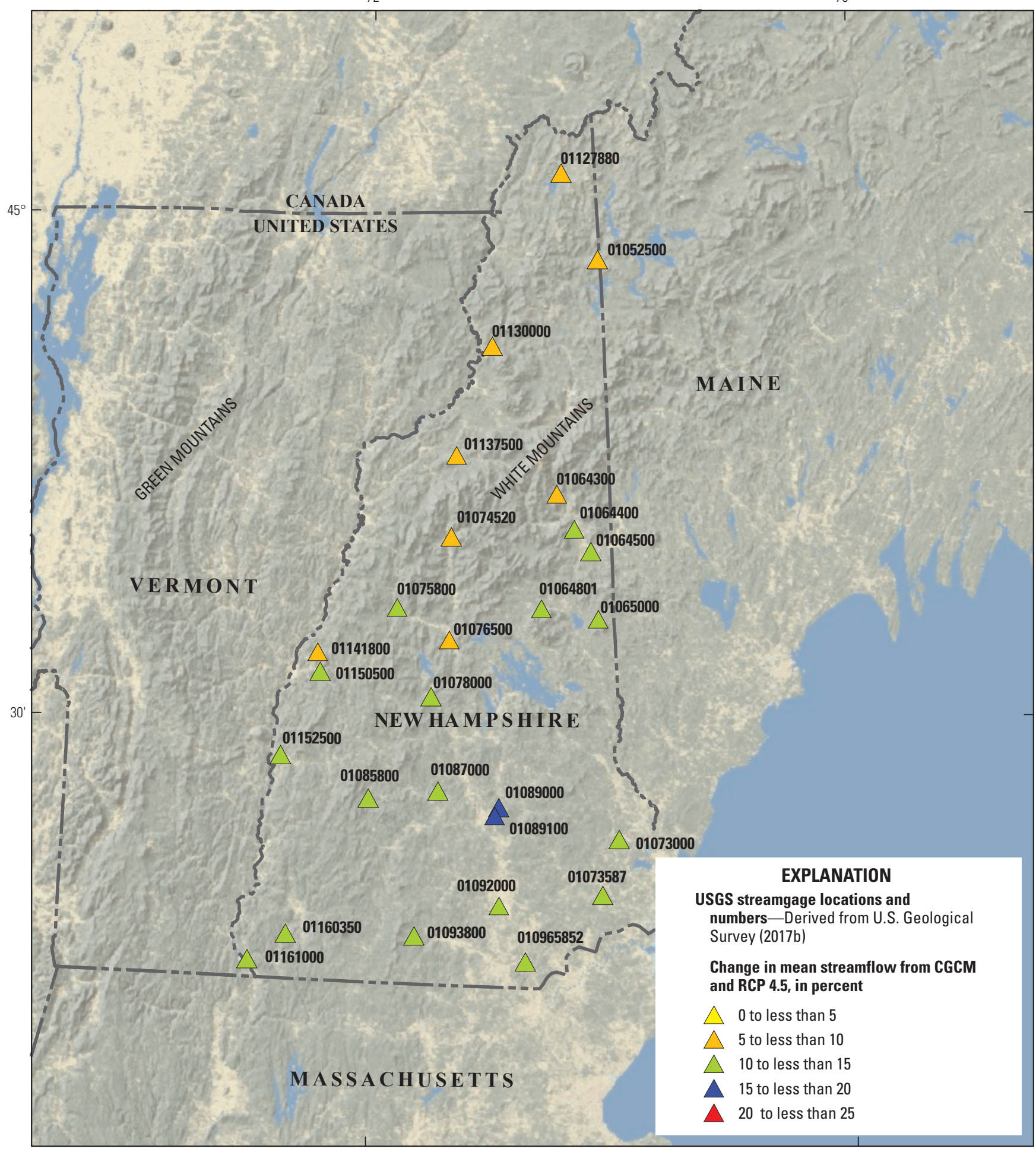

Base from U.S. Geological Survey The National Map digital data Albers equal area conic projection North American Datum 1983

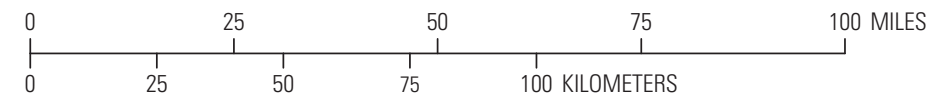

Figure 6. The spatial distribution of changes in simulated mean streamflow at the 27 calibration streamgages in New Hampshire between the current (1981-2000) period and the end-of-century (2081-2100) period using two general circulation models and the two emission scenarios: $A$, coupled general circulation model (CGCM) RCP 4.5, B, CGCM RCP 8.5, C, Geophysical Fluid Dynamics Laboratory (GFDL) model RCP 4.5, and D, GFDL RCP 8.5. The CGCM is the model designated MRI-CGCM3 from Yukimoto and others (2012); the GFDL is the model designated GFDL-ESM2G from the National Oceanic and Atmospheric Administration, Geophysical Fluid Dynamics Laboratory (2016). GCM, general circulation model; RCP, representative concentration pathway; USGS, U.S. Geological Survey. 


\section{$\boldsymbol{B}$}

$72^{\circ}$

$70^{\circ}$

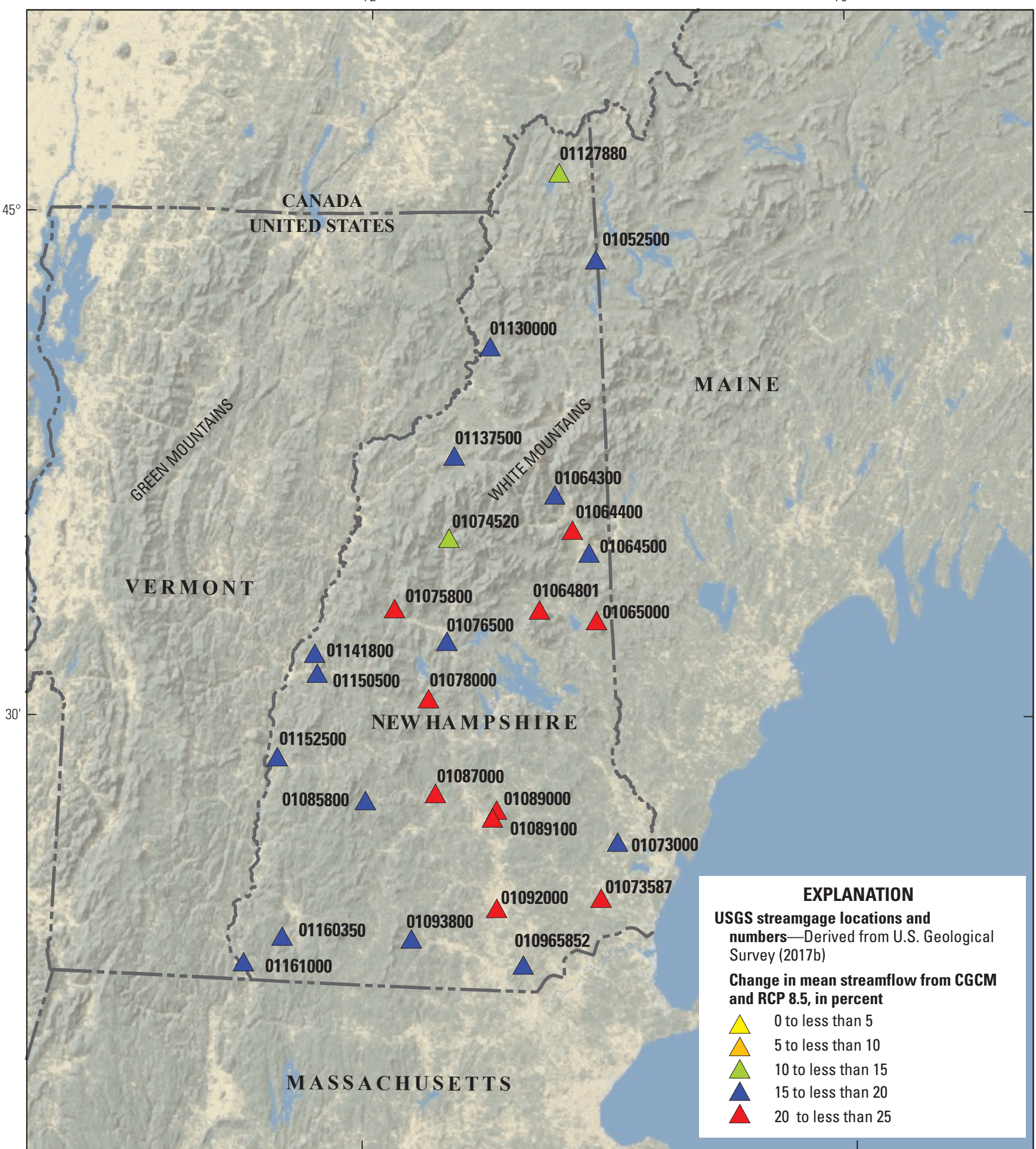

Base from U.S. Geological Survey

The National Map digital data

Albers equal area conic projection

North American Datum 1983

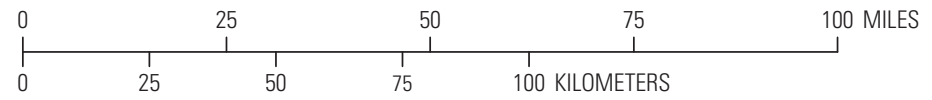

Figure 6. The spatial distribution of changes in simulated mean streamflow at the 27 calibration streamgages in New Hampshire between the current (1981-2000) period and the end-of-century (2081-2100) period using two general circulation models and the two emission scenarios: $A$, coupled general circulation model (CGCM) RCP 4.5, $B$, CGCM RCP 8.5, C, Geophysical Fluid Dynamics Laboratory (GFDL) model RCP 4.5, and D, GFDL RCP 8.5. The CGCM is the model designated MRI-CGCM3 from Yukimoto and others (2012); the GFDL is the model designated GFDL-ESM2G from the National Oceanic and Atmospheric Administration, Geophysical Fluid Dynamics Laboratory (2016). GCM, general circulation model; RCP, representative concentration pathway; USGS, U.S. Geological Survey.-Continued 
C

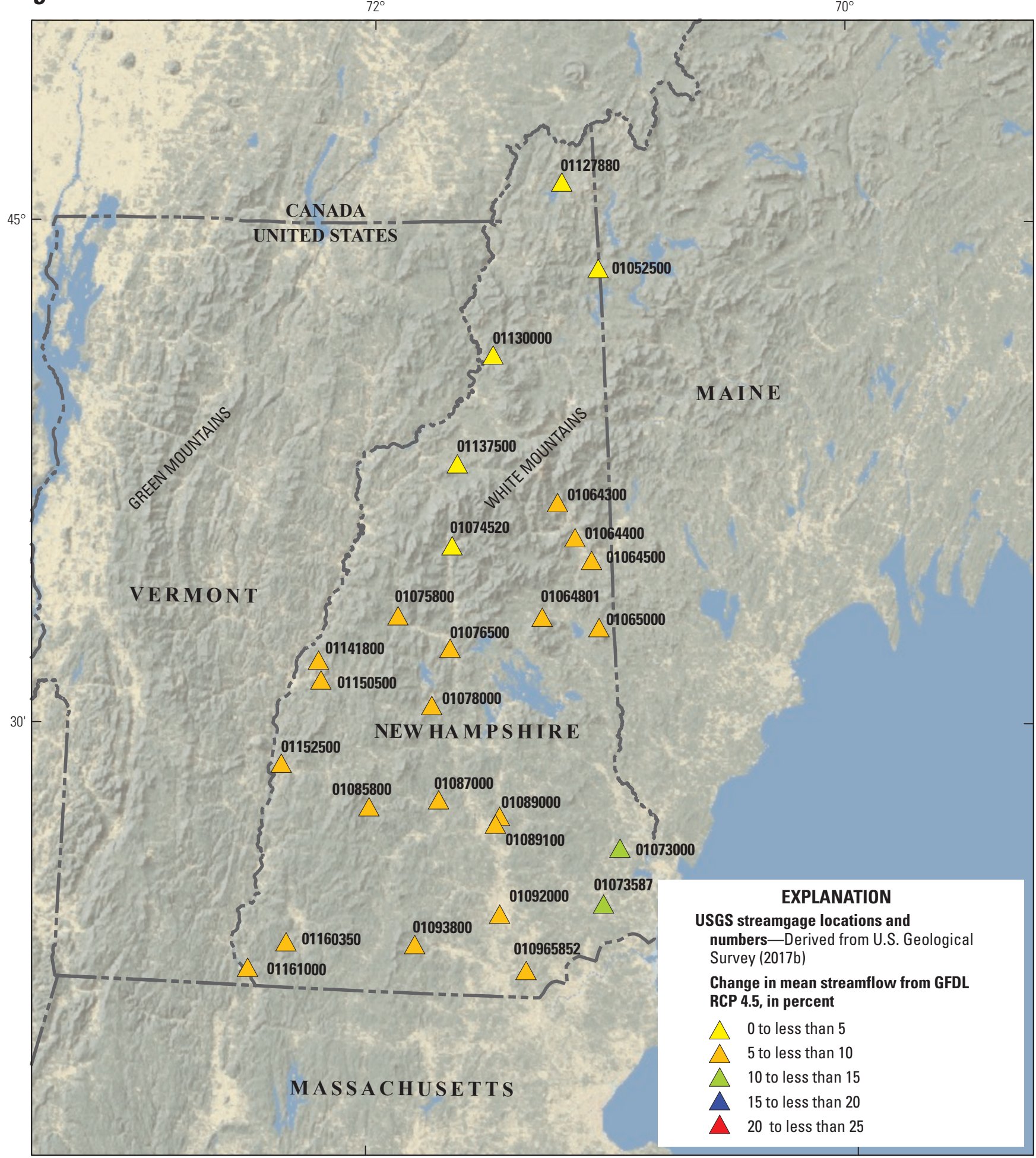

Base from U.S. Geological Survey The National Map digital data Albers equal area conic projection North American Datum 1983

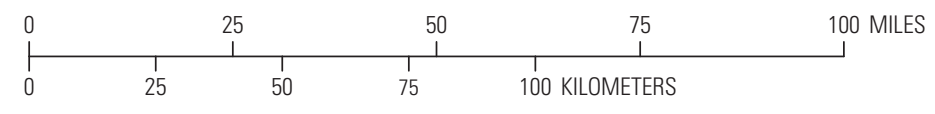

Figure 6. The spatial distribution of changes in simulated mean streamflow at the 27 calibration streamgages in New Hampshire between the current (1981-2000) period and the end-of-century (2081-2100) period using two general circulation models and the two emission scenarios: A, coupled general circulation model (CGCM) RCP 4.5, B, CGCM RCP 8.5, C, Geophysical Fluid Dynamics Laboratory (GFDL) model RCP 4.5, and D, GFDL RCP 8.5. The CGCM is the model designated MRI-CGCM3 from Yukimoto and others (2012); the GFDL is the model designated GFDL-ESM2G from the National Oceanic and Atmospheric Administration, Geophysical Fluid Dynamics Laboratory (2016). GCM, general circulation model; RCP, representative concentration pathway; USGS, U.S. Geological Survey.-Continued 


\section{D}

$72^{\circ}$

$70^{\circ}$

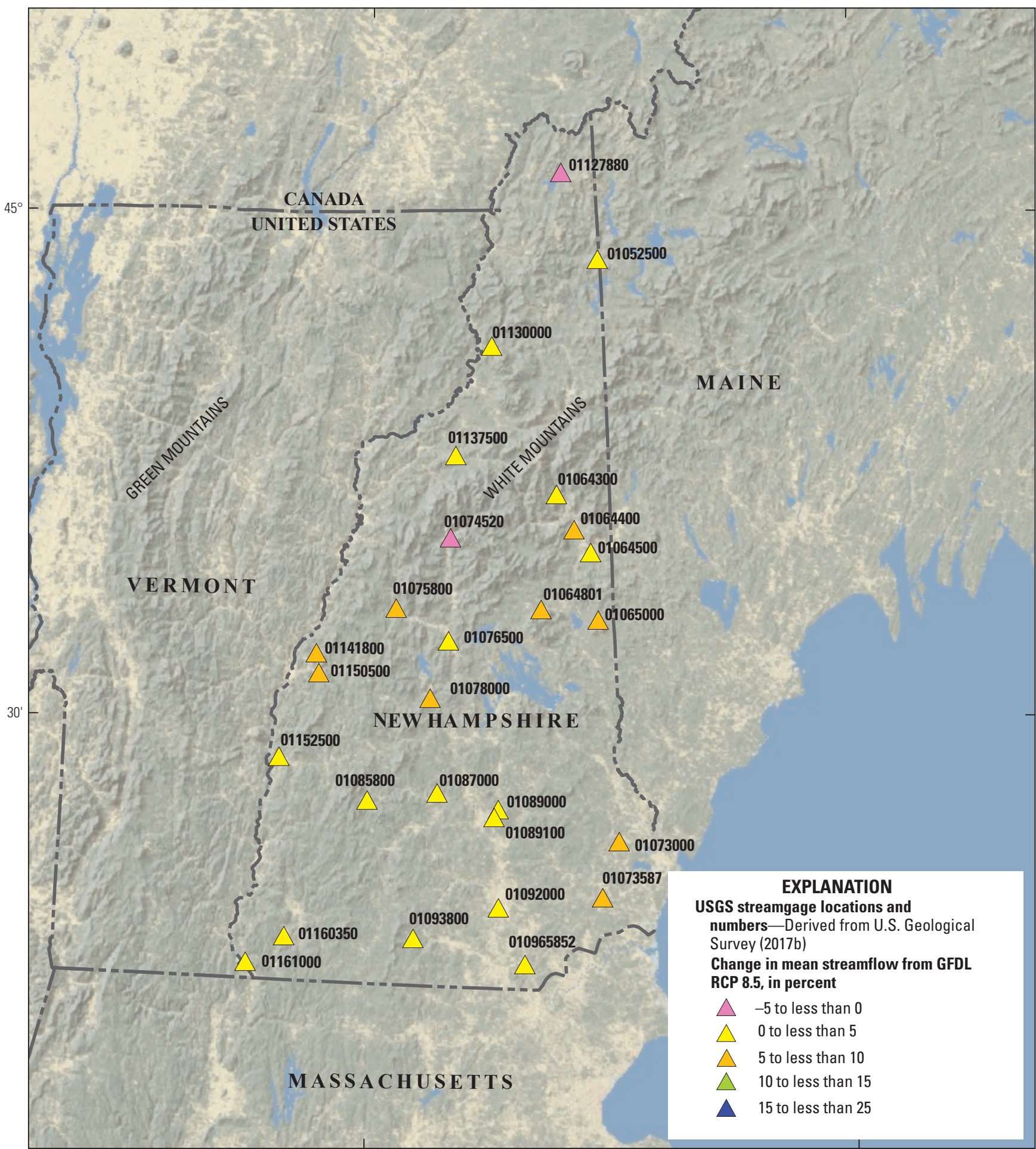

Base from U.S. Geological Survey

The National Map digital data

Albers equal area conic projection

North American Datum 1983

\begin{tabular}{|c|c|c|}
\hline & & \multirow[t]{2}{*}{100 MILES } \\
\hline & 25 & \\
\hline
\end{tabular}

Figure 6. The spatial distribution of changes in simulated mean streamflow at the 27 calibration streamgages in New Hampshire between the current (1981-2000) period and the end-of-century (2081-2100) period using two general circulation models and the two emission scenarios: $A$, coupled general circulation model (CGCM) RCP 4.5, B, CGCM RCP 8.5, C, Geophysical Fluid Dynamics Laboratory (GFDL) model RCP 4.5, and D, GFDL RCP 8.5. The CGCM is the model designated MRI-CGCM3 from Yukimoto and others (2012); the GFDL is the model designated GFDL-ESM2G from the National Oceanic and Atmospheric Administration, Geophysical Fluid Dynamics Laboratory (2016). GCM, general circulation model; RCP, representative concentration pathway; USGS, U.S. Geological Survey.-Continued 
Table 7. Simulated percent changes in average recharge in New Hampshire for 20-year periods using simulations made from five general circulation models and two emission scenarios.

[Values are for unweighted averages of statewide hydrologic response units (HRUs), in inches per year. CGCM, coupled general circulation model; CNRM, Centre National de Recherches Météorologiques; CSIRO, Commonwealth Scientific and Industrial Research Organisation; ESM, Earth system modeling; GFDL, Geophysical Fluid Dynamics Laboratory coupled model; Stdev, standard deviation; RCP, representative concentration pathway]

\begin{tabular}{|c|c|c|c|c|c|c|c|c|c|}
\hline \multirow{2}{*}{ Scenario } & \multirow{2}{*}{ Period } & \multirow{2}{*}{ Statistic } & \multicolumn{5}{|c|}{ General circulation model } & \multicolumn{2}{|c|}{ Composite } \\
\hline & & & CGCM & CNRM & CSIRO & ESM & GFDL & Mean & Stdev \\
\hline \multirow[t]{2}{*}{ RCP 4.5} & $2046-2065$ & Mean & -2.8 & -8.4 & 2.9 & -3.8 & -0.4 & -2.5 & 4.2 \\
\hline & & Stdev & -1.9 & -10.8 & 0.0 & -8.6 & -5.5 & -5.3 & 4.5 \\
\hline \multirow[t]{2}{*}{$\mathrm{RCP} 4.5$} & $2081-2100$ & Mean & 5.2 & -15.6 & -6.1 & -8.3 & -0.6 & -5.1 & 7.9 \\
\hline & & Stdev & 1.4 & -18.2 & -6.6 & -7.9 & -3.7 & -7.0 & 7.2 \\
\hline \multirow[t]{2}{*}{ RCP 8.5} & $2046-2065$ & Mean & 1.1 & -12.8 & -8.7 & -11.9 & -2.6 & -7.0 & 6.0 \\
\hline & & Stdev & -1.5 & -16.0 & -10.0 & -10.0 & -6.7 & -8.8 & 5.3 \\
\hline \multirow[t]{2}{*}{$\mathrm{RCP} 8.5$} & $2081-2100$ & Mean & 3.6 & -19.4 & -20.6 & -14.1 & -15.5 & -13.2 & 9.8 \\
\hline & & Stdev & 0.0 & -22.3 & -19.1 & -14.8 & -16.9 & -14.6 & 8.6 \\
\hline
\end{tabular}

Table 8. Simulated percent change in average snowfall in New Hampshire for 20-year periods using two emission scenarios and five general circulation models, in inches of snow.

[Values are for unweighted averages of statewide hydrologic response units (HRUs), in inches of snow, calculated as inches of snowwater equivalent (SWE) times 10. CGCM, coupled general circulation model; CNRM, Centre National de Recherches Météorologiques; CSIRO, Commonwealth Scientific and Industrial Research Organisation; ESM, Earth system model; GFDL, Geophysical Fluid Dynamics Laboratory coupled model; Stdev, standard deviation; RCP, representative concentration pathway]

\begin{tabular}{|c|c|c|c|c|c|c|c|c|c|}
\hline \multirow{2}{*}{ Month } & \multirow{2}{*}{ Scenario } & \multirow{2}{*}{ Time period } & \multicolumn{5}{|c|}{ General circulation model } & \multicolumn{2}{|c|}{ Composite } \\
\hline & & & CGCM & CNRM & CSIRO & ESM & GFDL & Mean & Stdev \\
\hline November & RCP 4.5 & 2046-2065 & -59.0 & -71.5 & -3.2 & -71.1 & -85.1 & -58.0 & 32.0 \\
\hline December & & & -51.4 & -50.1 & -45.5 & -51.4 & -37.0 & -47.1 & 6.1 \\
\hline January & & & -19.5 & -50.7 & -19.0 & -49.8 & -48.2 & -37.4 & 16.6 \\
\hline February & & & -18.5 & -11.5 & -35.8 & -28.5 & -15.0 & -21.8 & 10.1 \\
\hline March & & & 8.8 & -50.4 & -60.5 & -71.0 & -56.2 & -45.9 & 31.5 \\
\hline November & RCP 8.5 & $2046-2065$ & -67.6 & -85.0 & -80.0 & -94.1 & -44.1 & -74.2 & 19.3 \\
\hline December & & & -54.8 & -68.2 & -71.7 & -43.8 & -52.8 & -58.3 & 11.5 \\
\hline January & & & -34.9 & -53.0 & -47.6 & -54.4 & -50.4 & -48.0 & 7.8 \\
\hline February & & & -24.2 & -45.5 & -42.8 & -38.6 & -41.2 & -38.5 & 8.4 \\
\hline March & & & -33.4 & -66.8 & -76.2 & -77.6 & -72.8 & -65.4 & 18.4 \\
\hline November & $\mathrm{RCP} 4.5$ & $2081-2100$ & -79.7 & -53.0 & -73.6 & -90.7 & -81.5 & -75.7 & 14.1 \\
\hline December & & & -67.2 & -59.0 & -60.3 & -57.9 & -54.1 & -59.7 & 4.8 \\
\hline January & & & -1.1 & -62.2 & -51.3 & -44.5 & -26.4 & -37.1 & 24.0 \\
\hline February & & & -25.2 & -27.6 & -45.2 & -35.3 & -12.7 & -29.2 & 12.1 \\
\hline March & & & -13.6 & -63.9 & -80.1 & -69.6 & -60.0 & -57.4 & 25.7 \\
\hline November & RCP 8.5 & $2081-2100$ & -98.7 & -92.6 & -93.4 & -98.9 & -90.0 & -94.7 & 3.9 \\
\hline December & & & -84.5 & -79.9 & -79.4 & -83.2 & -71.3 & -79.7 & 5.1 \\
\hline January & & & -47.7 & -88.4 & -77.4 & -70.3 & -72.2 & -71.2 & 14.9 \\
\hline February & & & -55.3 & -86.4 & -79.4 & -73.8 & -69.1 & -72.8 & 11.7 \\
\hline March & & & -71.4 & -89.7 & -84.6 & -86.1 & -82.2 & -82.8 & 6.9 \\
\hline
\end{tabular}




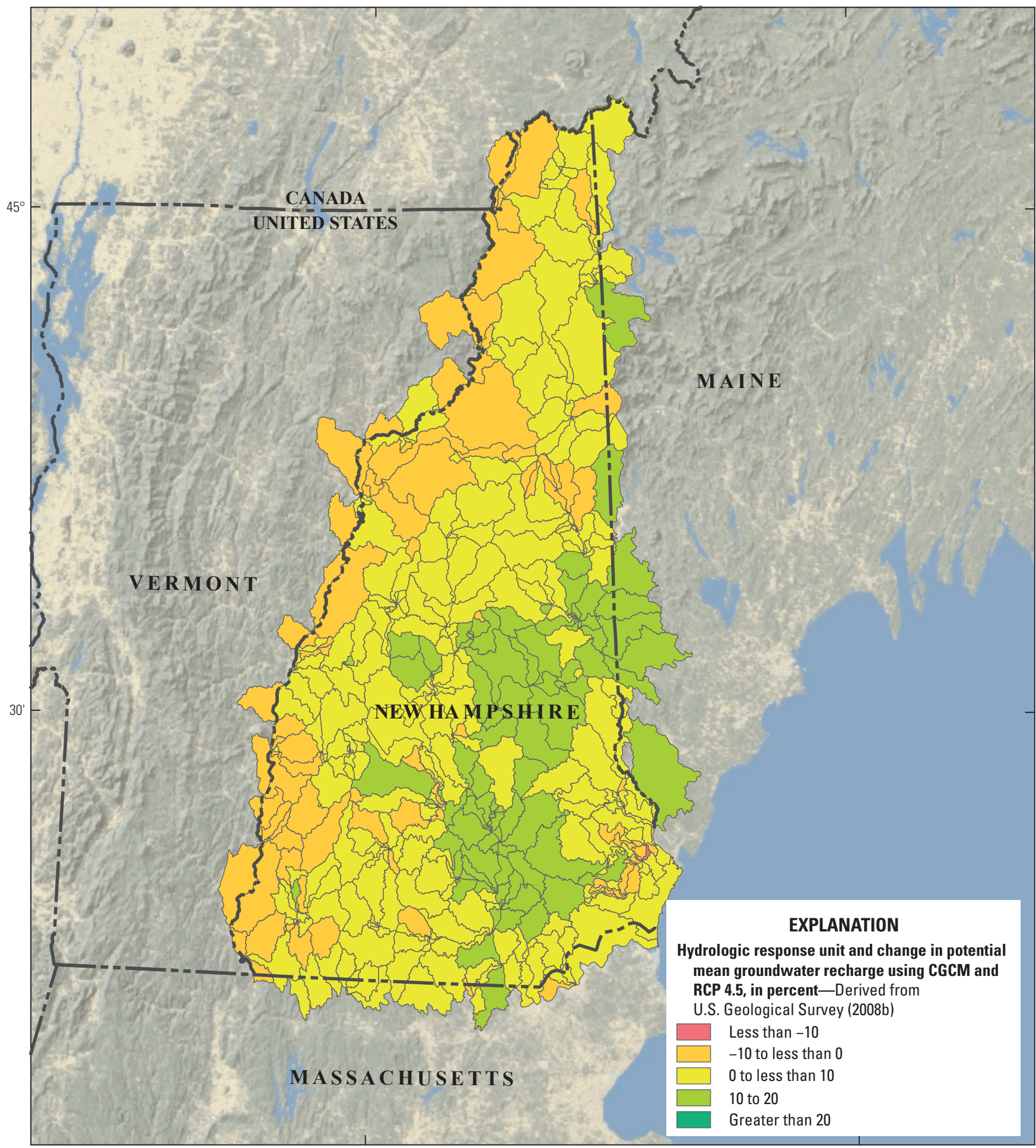

Base from U.S. Geological Survey The National Map digital data Albers equal area conic projection North American Datum 1983

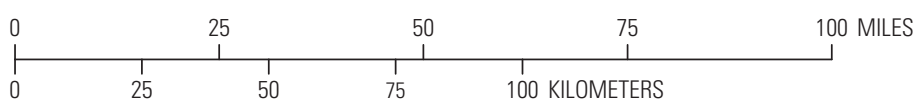

Figure 7. The spatial distribution of change in simulated mean groundwater recharge at hydrologic response units in New Hampshire between the current period (1981-2000) and the end-of-century period (2081-2100), using two general circulation models (GCMs) and the two emission scenarios: $A$, combined general circulation model (CGCM) RCP 4.5, B, CGCM RCP 8.5, C, Geophysical Fluid Dynamics Laboratory (GFDL) RCP 4.5, and D, GFDL RCP 8.5. The CGCM is the model designated MRI-CGCM3 from Yukimoto and others (2012); the GFDL is the model designated GFDL-ESM2G from the National Oceanic and Atmospheric Administration, Geophysical Fluid Dynamics Laboratory (2016). RCP, representative concentration pathway. 


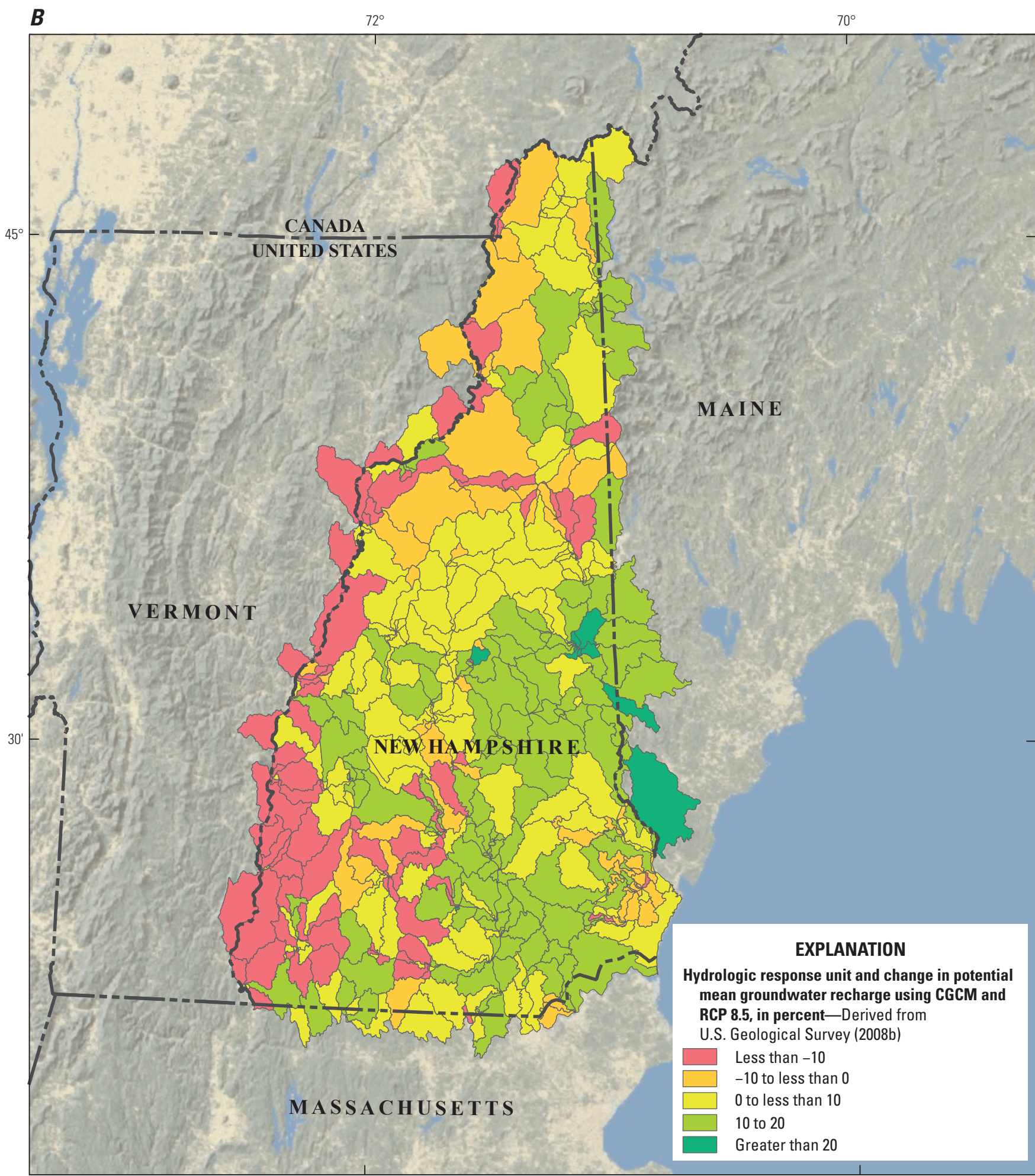

Base from U.S. Geological Survey The National Map digital data

Albers equal area conic projection North American Datum 1983

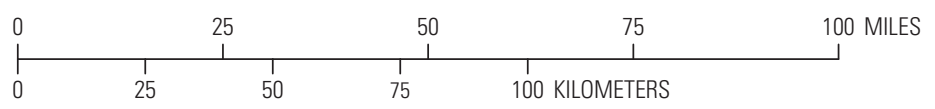

Figure 7. The spatial distribution of change in simulated mean groundwater recharge at hydrologic response units in New Hampshire between the current period (1981-2000) and the end-of-century period (2081-2100), using two general circulation models (GCMs) and the two emission scenarios: $A$, combined general circulation model (CGCM) RCP 4.5, $B$, CGCM RCP 8.5, C, Geophysical Fluid Dynamics Laboratory (GFDL) RCP 4.5, and D, GFDL RCP 8.5. The CGCM is the model designated MRI-CGCM3 from Yukimoto and others (2012); the GFDL is the model designated GFDL-ESM2G from the National Oceanic and Atmospheric Administration, Geophysical Fluid Dynamics Laboratory (2016). RCP, representative concentration pathway.-Continued 


\section{C} $72^{\circ}$ $70^{\circ}$

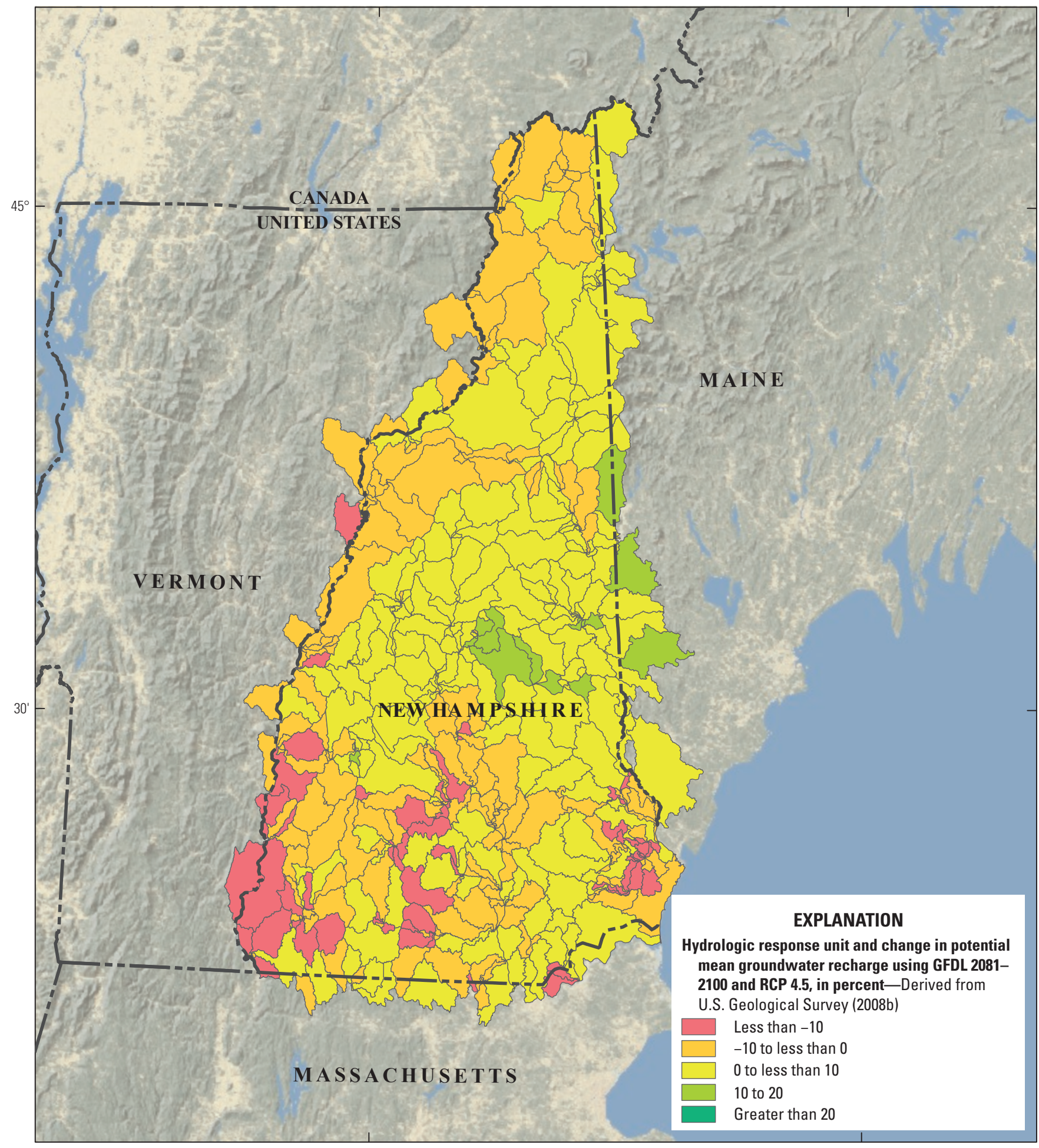

Base from U.S. Geological Survey The National Map digital data

Albers equal area conic projection North American Datum 1983

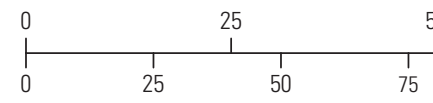
50

$50-75$

100 KILOMETERS

Figure 7. The spatial distribution of change in simulated mean groundwater recharge at hydrologic response units in New Hampshire between the current period (1981-2000) and the end-of-century period (2081-2100), using two general circulation models (GCMs) and the two emission scenarios: $A$, combined general circulation model (CGCM) RCP 4.5, $B$, CGCM RCP 8.5, C, Geophysical Fluid Dynamics Laboratory (GFDL) RCP 4.5, and D, GFDL RCP 8.5. The CGCM is the model designated MRI-CGCM3 from Yukimoto and others (2012); the GFDL is the model designated GFDL-ESM2G from the National Oceanic and Atmospheric Administration, Geophysical Fluid Dynamics Laboratory (2016). RCP, representative concentration pathway.-Continued 


\section{D}

$72^{\circ}$

$70^{\circ}$

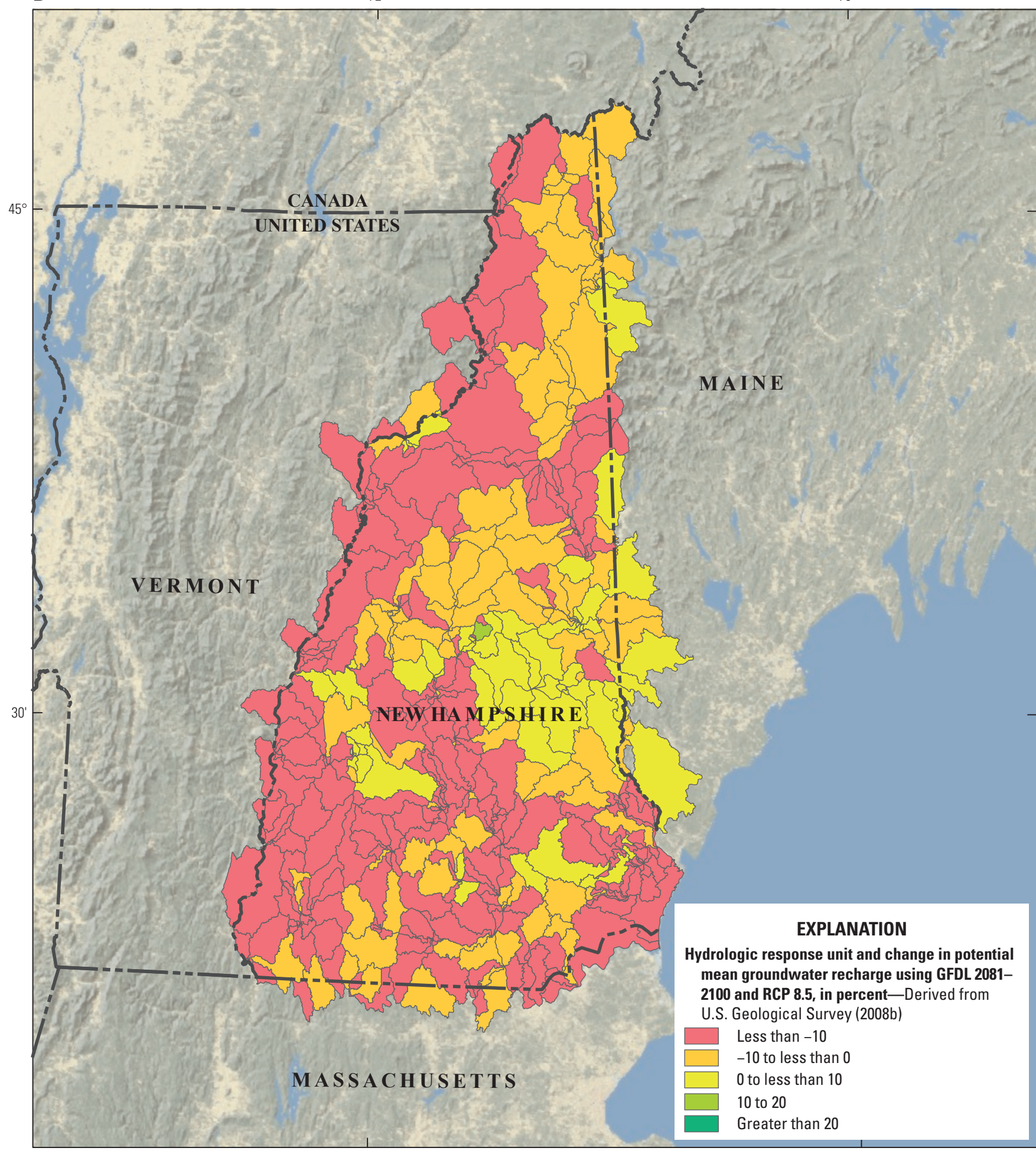

Base from U.S. Geological Survey The National Map digital data Albers equal area conic projection North American Datum 1983

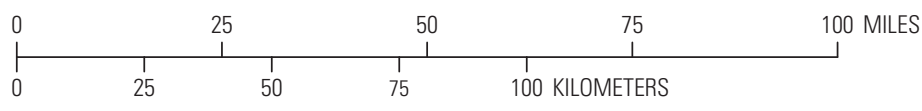

Figure 7. The spatial distribution of change in simulated mean groundwater recharge at hydrologic response units in New Hampshire between the current period (1981-2000) and the end-of-century period (2081-2100), using two general circulation models (GCMs) and the two emission scenarios: $A$, combined general circulation model (CGCM) RCP 4.5, $B$, CGCM RCP 8.5, C, Geophysical Fluid Dynamics Laboratory (GFDL) RCP 4.5, and D, GFDL RCP 8.5. The CGCM is the model designated MRI-CGCM3 from Yukimoto and others (2012); the GFDL is the model designated GFDL-ESM2G from the National Oceanic and Atmospheric Administration, Geophysical Fluid Dynamics Laboratory (2016). RCP, representative concentration pathway.-Continued 


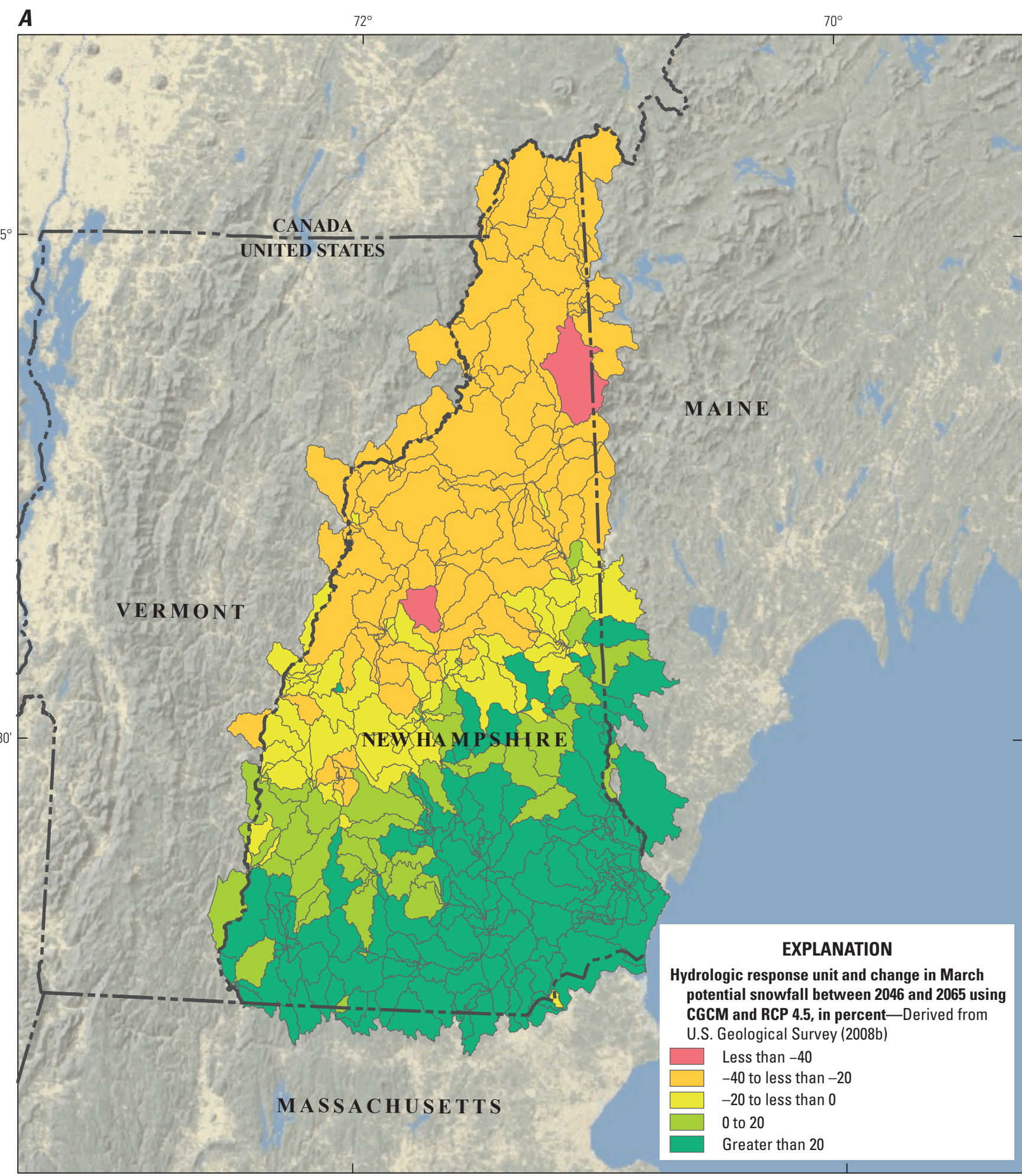

Base from U.S. Geological Survey The National Map digital data Albers equal area conic projection North American Datum 1983

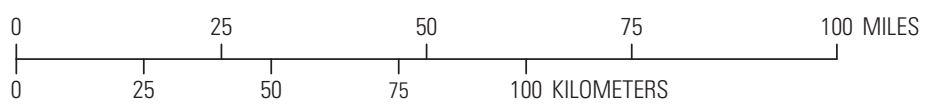

Figure 8. The spatial distribution of percent changes in simulated monthly snowfall at hydrologic response units in New Hampshire between the current (1981-2000) period and the midcentury (2046-2065) and end-of-century (2081-2100) period, using two general circulation models (GCMs) and the two emission scenarios: $A$, March, CGCM RCP 4.5, 2046 to 2065; $B$, March, CGCM RCP 4.5, 2081 to 2100; C, November, GFDL RCP 8.5, 2046 to 2065; D, February, GFDL RCP 4.5, 2046 to 2065; and E, February, GFDL RCP 4.5, 2081 to 2100. The CGCM is the model designated MRI-CGCM3 from Yukimoto and others (2012); the GFDL is the model designated GFDL-ESM2G from the National Oceanic and Atmospheric Administration, Geophysical Fluid Dynamics Laboratory (2016). RCP, representative concentration pathway. 


\section{B} $72^{\circ}$ $70^{\circ}$

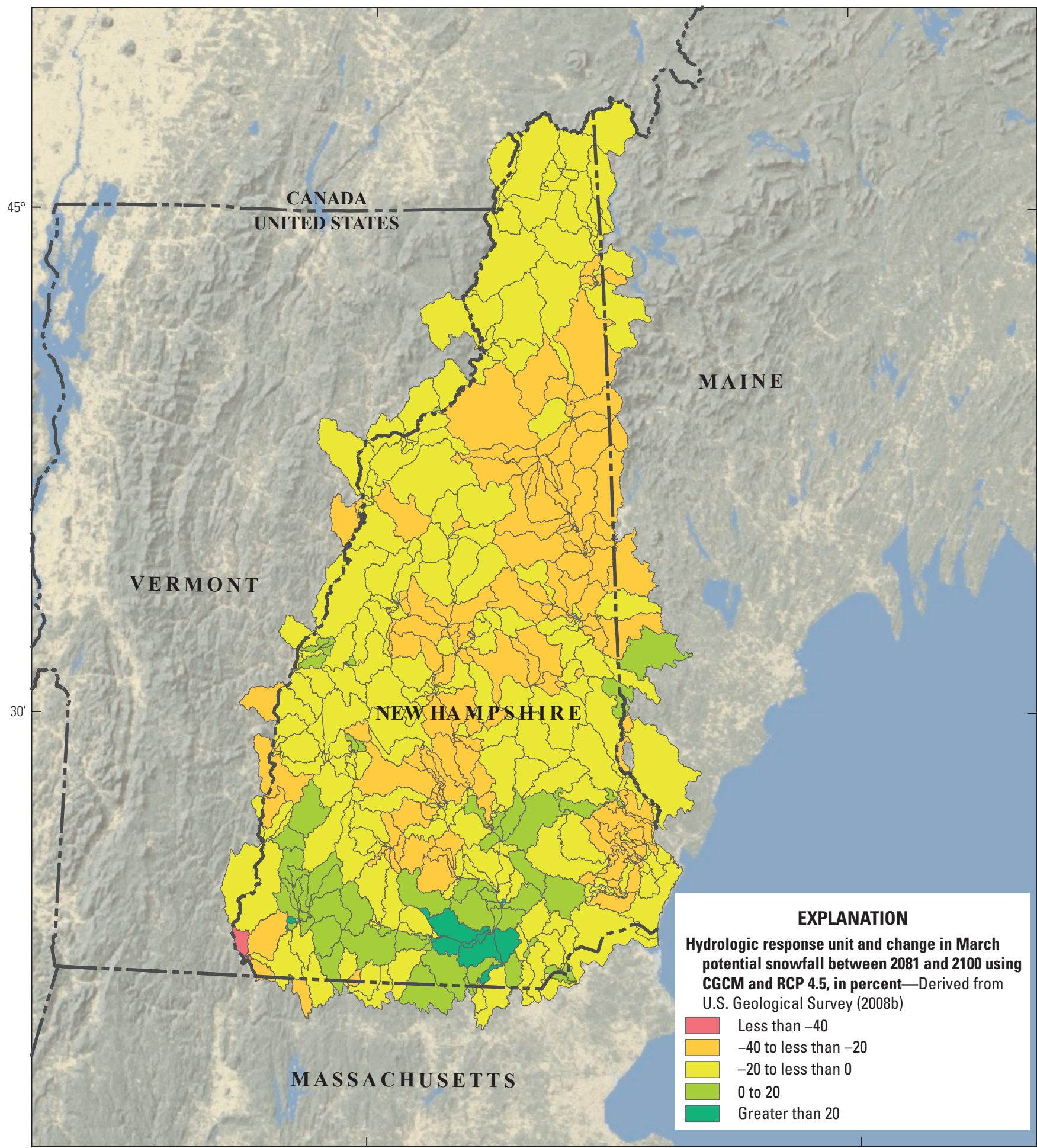

Base from U.S. Geological Survey The National Map digital data Albers equal area conic projection North American Datum 1983

\begin{tabular}{|c|c|c|c|c|c|}
\hline 0 & & & & $\begin{array}{c}75 \\
1\end{array}$ & 100 MILES \\
\hline 0 & $\begin{array}{l}1 \\
25\end{array}$ & 50 & $\begin{array}{c}1 \\
75\end{array}$ & 100 KILOMETERS & \\
\hline
\end{tabular}

Figure 8. The spatial distribution of percent changes in simulated monthly snowfall at hydrologic response units in New Hampshire between the current (1981-2000) period and the midcentury (2046-2065) and end-of-century (2081-2100) period, using two general circulation models (GCMs) and the two emission scenarios: $A$, March, CGCM RCP 4.5, 2046 to 2065; $B$, March, CGCM RCP 4.5, 2081 to 2100; C, November, GFDL RCP 8.5, 2046 to 2065; D, February, GFDL RCP 4.5, 2046 to 2065; and E, February, GFDL RCP 4.5, 2081 to 2100. The CGCM is the model designated MRI-CGCM3 from Yukimoto and others (2012); the GFDL is the model designated GFDL-ESM2G from the National Oceanic and Atmospheric Administration, Geophysical Fluid Dynamics Laboratory (2016). RCP, representative concentration pathway.-Continued 


\section{C} $72^{\circ}$ $70^{\circ}$

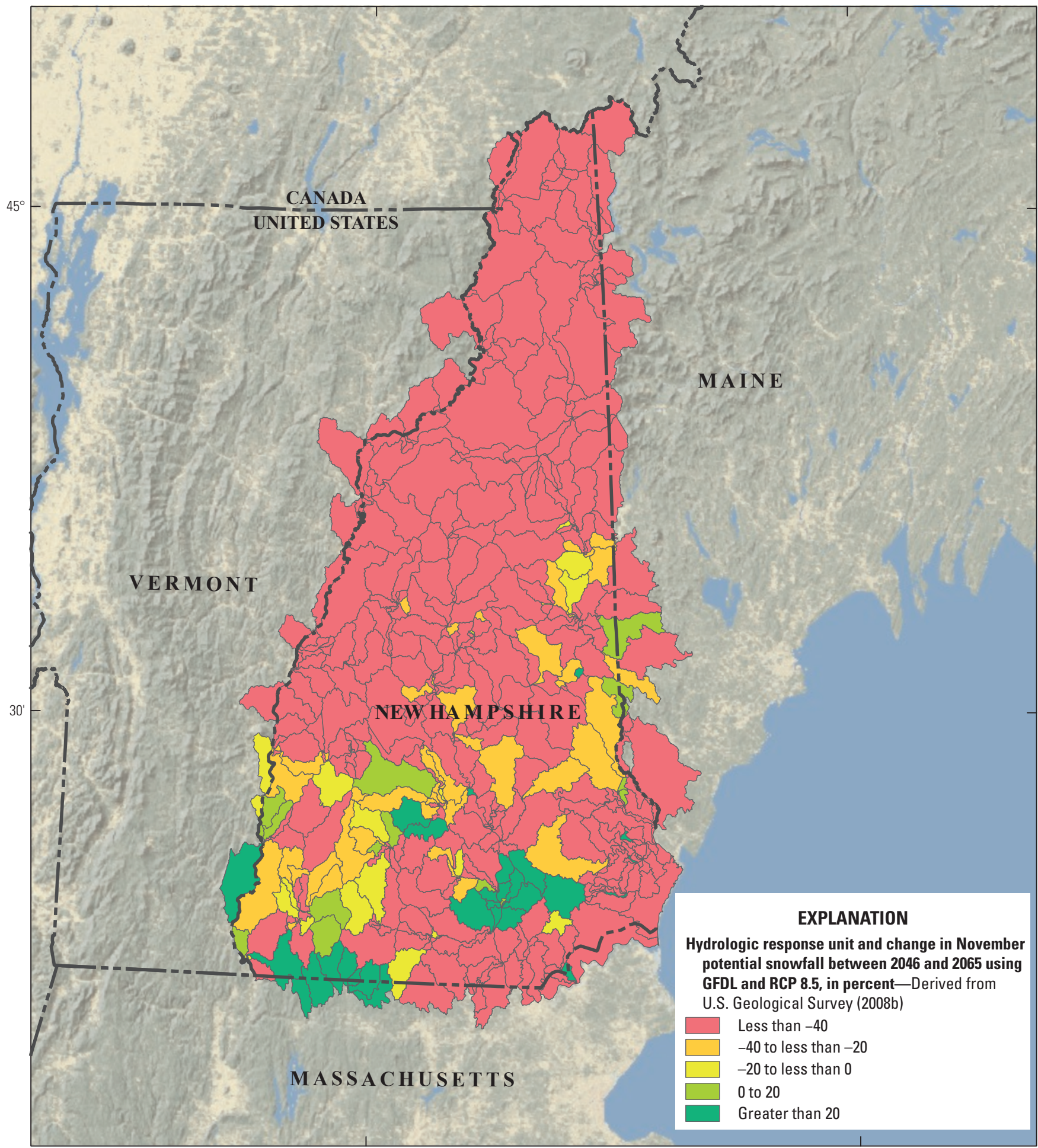

Base from U.S. Geological Survey The National Map digital data Albers equal area conic projection North American Datum 1983

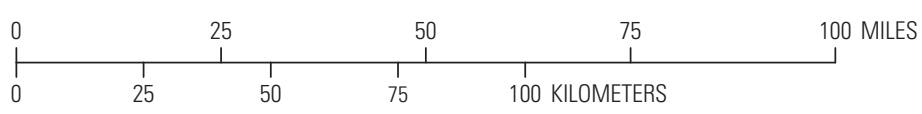

Figure 8. The spatial distribution of percent changes in simulated monthly snowfall at hydrologic response units in New Hampshire between the current (1981-2000) period and the midcentury (2046-2065) and end-of-century (2081-2100) period, using two general circulation models (GCMs) and the two emission scenarios: $A$, March, CGCM RCP 4.5, 2046 to 2065; $B$, March, CGCM RCP 4.5, 2081 to 2100; C, November, GFDL RCP 8.5, 2046 to 2065; D, February, GFDL RCP 4.5, 2046 to 2065; and E, February, GFDL RCP 4.5, 2081 to 2100. The CGCM is the model designated MRI-CGCM3 from Yukimoto and others (2012); the GFDL is the model designated GFDL-ESM2G from the National Oceanic and Atmospheric Administration, Geophysical Fluid Dynamics Laboratory (2016). RCP, representative concentration pathway.-Continued 


\section{D}

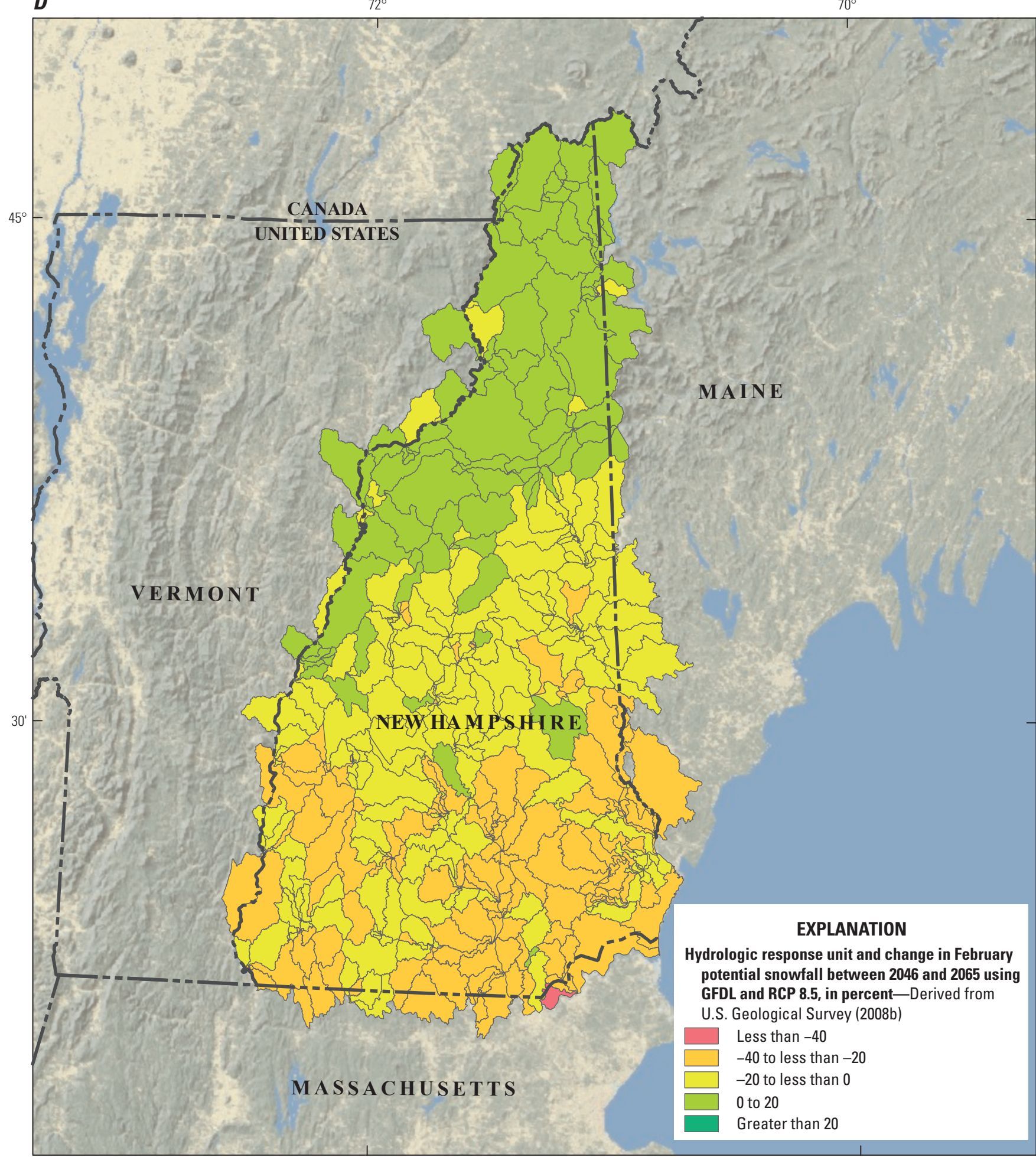

Base from U.S. Geological Survey The National Map digital data Albers equal area conic projection North American Datum 1983

\begin{tabular}{|c|c|c|c|c|c|}
\hline 0 & & 7 & $\begin{array}{c}50 \\
\perp\end{array}$ & $\begin{array}{c}75 \\
\perp \\
\end{array}$ & 100 MILES \\
\hline 0 & 25 & 50 & 75 & 100 KILOMETERS & \\
\hline
\end{tabular}

Figure 8. The spatial distribution of percent changes in simulated monthly snowfall at hydrologic response units in New Hampshire between the current (1981-2000) period and the midcentury (2046-2065) and end-of-century (2081-2100) period, using two general circulation models (GCMs) and the two emission scenarios: $A$, March, CGCM RCP 4.5, 2046 to 2065; $B$, March, CGCM RCP 4.5, 2081 to 2100; C, November, GFDL RCP 8.5, 2046 to 2065; D, February, GFDL RCP 4.5, 2046 to 2065; and E, February, GFDL RCP 4.5, 2081 to 2100. The CGCM is the model designated MRI-CGCM3 from Yukimoto and others (2012); the GFDL is the model designated GFDL-ESM2G from the National Oceanic and Atmospheric Administration, Geophysical Fluid Dynamics Laboratory (2016). RCP, representative concentration pathway.-Continued 


\section{E}

$72^{\circ}$

$70^{\circ}$

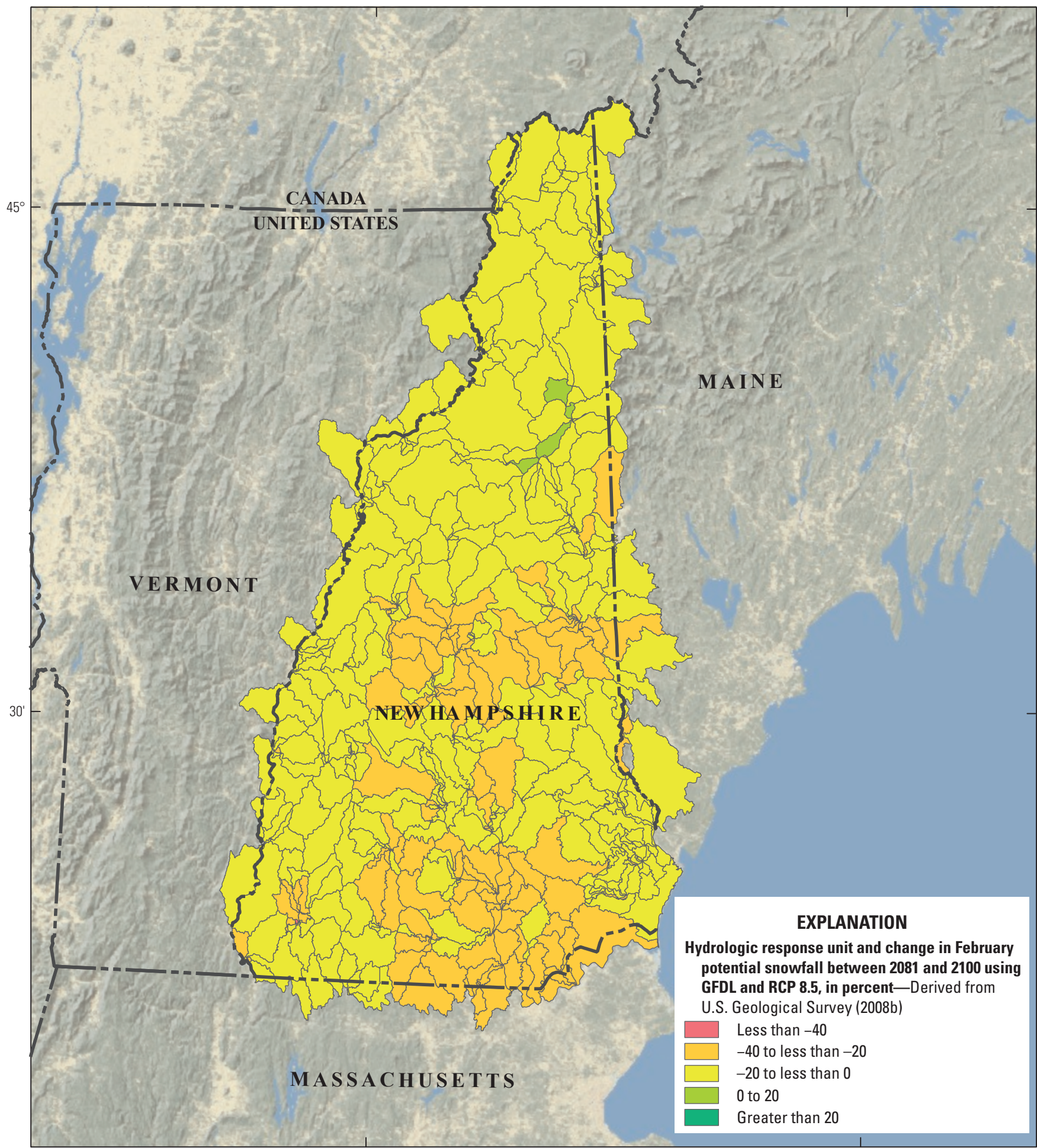

Base from U.S. Geological Survey

The National Map digital data

Albers equal area conic projection

North American Datum 1983

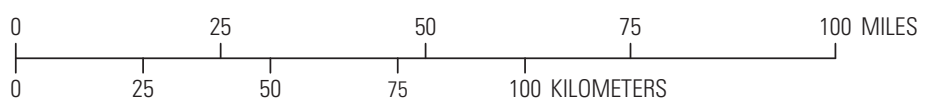

Figure 8. The spatial distribution of percent changes in simulated monthly snowfall at hydrologic response units in New Hampshire between the current (1981-2000) period and the midcentury (2046-2065) and end-of-century (2081-2100) period, using two general circulation models (GCMs) and the two emission scenarios: $A$, March, CGCM RCP 4.5, 2046 to 2065; $B$, March, CGCM RCP 4.5, 2081 to 2100; C, November, GFDL RCP 8.5, 2046 to 2065; D, February, GFDL RCP 4.5, 2046 to 2065; and E, February, GFDL RCP 4.5, 2081 to 2100. The CGCM is the model designated MRI-CGCM3 from Yukimoto and others (2012); the GFDL is the model designated GFDL-ESM2G from the National Oceanic and Atmospheric Administration, Geophysical Fluid Dynamics Laboratory (2016). RCP, representative concentration pathway.-Continued 
The potential effects of increased impervious surface were explored via a sensitivity analysis for the coastal region of New Hampshire, an area that is projected to increase in population in the coming years. By doubling the impervious surface in two watersheds in south coastal New Hampshire including streamgage 01073587 (the Exeter River) and streamgage 0107300 (the Oyster River), the PRMS model simulated a 30-percent increase in mean streamflow, with the increased mean driven by larger high streamflows. Along with the larger high streamflows, there was a reduction in recharge by 5 to 10 percent, which then would result in lower base flows. These effects of changing streamflow and recharge have been documented in previous studies in New England (Ahearn and Bjerklie, 2010; Bjerklie and others, 2010a) using PRMS.

Given the variability of future groundwater recharge across the State, particularly the observation that increased recharge is expected primarily in the southeastern and coastal areas of the State, the interaction with changing land use is an important consideration for further analysis. For example, the southeastern and coastal areas of the State are expected to be areas of future growth and development (Bjerklie and others, 2015). These areas then would be subject to potential reductions in recharge because of increased impervious surface, while at the same time experiencing increased recharge resulting from climate change. Similarly, this region of the State is expected to experience increases in streamflow resulting from climate change, which will be compounded by increased streamflow from increased development and impervious surface.

\section{Model Limitations}

This study emphasizes the importance of understanding predicted trends in streamflow, snowmelt, and base flow from potential climate change through the hydrologic responses of models. Episodic events such as floods, which are affected by hourly and finer time-scale precipitation, are not addressed in this study. Pursuant to the discussion of the model calibration, simulated daily and monthly time series are likely subject to greater uncertainty where the calibration statistics are unsatisfactory. Other limitations include the following circumstances.

- Water withdrawals and returns, interbasin transfers, and changes in land use and land cover are not simulated.

- The effect of frozen ground on runoff is not simulated (the version of PRMS used in this study does not account for this process).

- The future GCM input datasets represent one specific climate realization and, therefore, may not represent the expected future conditions, but rather one of a population of equally likely possible conditions. There are many uncertainties in the GCM model simulations, which need to be understood (see Wooten, 2016).

- The scale of the model (approximate HUC-12 scale) is such that more localized hydrologic conditions, such as impervious surface, soil and geologic heterogeneity, small scale wetlands, and surface ponding that may affect specific areas, may not be well represented in the model. Conditions and processes that may be important locally may be smoothed or overwhelmed at the larger scale.

- Similar to the effects of model scale, downscaling of weather data from the historical datasets and from the GCMs may not capture the local scale variability of weather that may be associated with specific physiographic features.

Hydrologic effects associated with land-use and landcover change could be important in trends of possible future change and could be a more important driver of hydrologic change than climate change in some areas. The climate scenarios simulated in this study are possibilities only. The reality could be within the range of GCMs and scenarios modeled. Although not a limitation, it is important to note that according to the IPCC report (Intergovernmental Panel on Climate Change, 2007), the modeled scenarios are more likely to occur than a return to the norm of our past experiences during the reference period of the last few decades of the 20th century.

\section{Related USGS Datasets}

A number of output datasets developed in this study (table 9) are available (Bjerklie and Sturtevant, 2017). The input data and the PRMS model used to generate the output data have been archived within the USGS model archive system. Additionally, the 20 -year calibration and simulation datasets used for the study are archived in Bjerklie and Sturtevant (2017). The datasets include simulated data derived from the five GCMs used in this study for a 30-year reference time frame (1976-2005) and for a 90-year future period (20102099) in order to provide continuous data for the 21 st century. The data are presented in monthly time steps for each HRU in the model and in monthly and daily time steps for calibration streamgages where the NSE statistic is greater than 0.5. The data deliverable will provide the individual climate realizations for each of the five models and two emission scenarios. 


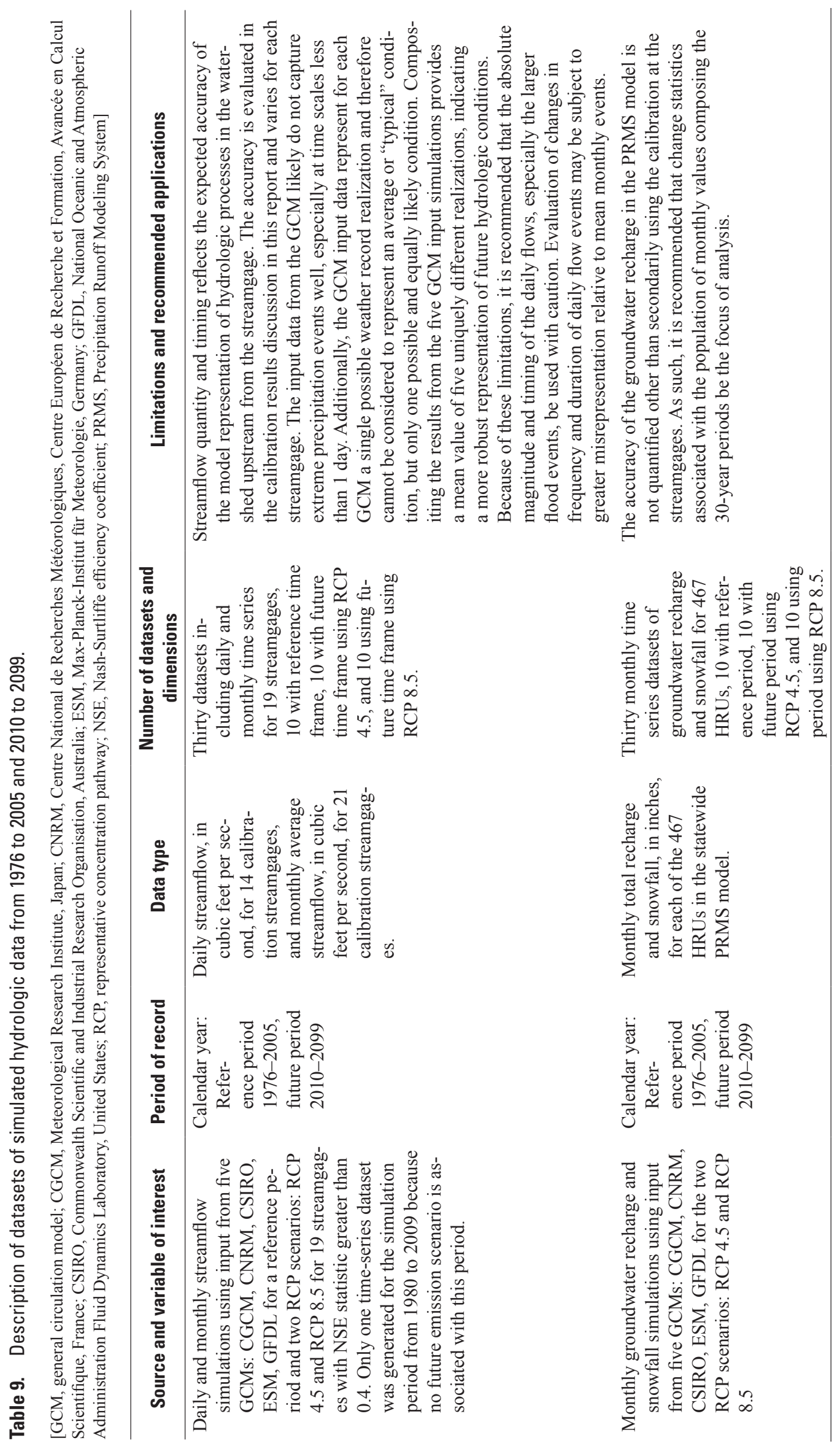




\section{Summary and Conclusions}

The State of New Hampshire had need of hydrologic simulations to meet planning requirements for infrastructure and other projects, and in response, the U.S. Geological Survey, in cooperation with the New Hampshire Departments of Environmental Services and Health and Human Services, developed a statewide Precipitation Runoff Modeling System (PRMS) hydrologic model designed to provide simulations of projected change in streamflow, groundwater recharge, and snowfall in response to climate change projections. Two emissions scenarios were used with five general circulation models (GCMs). In general, the statewide hydrologic model is considered to be well calibrated across the State; however, a number of streams, primarily at higher elevations, had relatively poor daily simulations. The model calibration at the monthly time step is considerably better across the State than the calibration at the daily time step. The statistics for change in streamflow, groundwater recharge, and snowfall may be considered more independent of the PRMS model calibration than of data input when comparing model-derived current (1981-2000) and future (2046-65 and 2081-2100) conditions. Additionally, concerns that the PRMS model calibration may not be representative of future conditions because some of the parameter values are dependent on air temperature were investigated. Parameter values dependent on air temperature, especially the parameters that control potential evapotranspiration, have been shown through sensitivity analysis to have only minor possible effects (less than 10 percent) over the range of expected changes in temperature.

Results of hydrologic simulations using the GCM projections of climate indicate increased streamflow across the State with large increases in streamflow during the late fall, winter, and early spring, and general decreases during late spring, summer, and early fall. Simulations project general decreases in groundwater recharge in the Connecticut River Valley and at high elevations and increases in coastal and lowland areas of the State. Total winter snowfall is projected to steadily decrease across the State as a whole, but there is a possibility of increased snowfall in some locations, particularly during November, February, and March. The simulated future changes in recharge and snowfall are predicted to vary across the State because of such factors as topography and elevation. In response to potential changes in streamflow, groundwater recharge, and snowfall amounts and variability, planning for infrastructure needs and public safety may need to be flexible and will depend on the location and the range of possible outcomes indicated by the various model simulations. Additionally, hydrologic systems may no longer be considered stable and predictable, thus possible future hydrologic conditions may need to be considered in planning and design of infrastructure and other projects.

Compositing the results from the five GCM input simulations for each of the two emissions scenarios provides mean values for five uniquely different future climate realizations per scenario, indicating a robust representation of future hydrologic conditions. The absolute magnitude and timing of the daily flows, especially the larger floods, are best used with caution and only for streamgages that had satisfactory simulations. Evaluation of changes in accumulated monthly and seasonal flow volumes are considered to be less subject to misrepresentations and therefore more meaningful to understanding and planning for possible changes in the hydrologic conditions.

\section{References Cited}

Ahearn, E.A., and Bjerklie, D.M., 2010, Connecticut Highlands technical report-Documentation of the regional rainfall-runoff model: U.S. Geological Survey Open-File Report 2010-1187, 42 p., appendix, accessed September 2015 at https://pubs.er.usgs.gov/publication/ofr20101187.

Bjerklie, D.M., and Sturtevant, Luke, 2017, Thirty- and ninety-year datasets of streamflow, groundwater recharge, and snowfall simulating potential hydrologic response to climate change in the 21 st century in New Hampshire: U.S. Geological Survey data release, https://doi.org/10.5066/F76T0KJZ.

Bjerklie, D.M., Ayotte, J.D., and Cahillane, M.J., 2015, Simulating hydrologic response to climate change scenarios in four selected watersheds of New Hampshire: U.S. Geological Survey Scientific Investigations Report 2015-5047, 53 p., accessed September 2015 at https://doi.org/10.3133/ $\operatorname{sir} 20155047$.

Bjerklie, D.M., Hay, L.E., and Markstrom, S.L., 2012, Watershed scale response to climate change-Pomperaug River watershed, Connecticut: U.S. Geological Survey Fact Sheet 2011-3122, 6 p. [Also available at https://pubs.er.usgs.gov/ publication/fs20113122.]

Bjerklie, D.M., Starn, J.J., and Tamayo, Claudia, 2010a, Estimation of the effects of land-use and groundwater withdrawals on streamflow for the Pomperaug River, Connecticut: U.S. Geological Survey Scientific Investigations Report 2010-5114, 81 p. [Also available at http://pubs.er.usgs.gov/ publication/sir20105114.]

Bjerklie, D.M., Trombley, T.J., and Viger, R.J., 2010b, Simulations of historical and future trends in snowfall and groundwater recharge for basins draining to Long Island Sound: Earth Interactions, v. 15, no. 34, p. 1-35.

Burns, D.A., Kraus, Julian, and McHale, M.R., 2007, Recent climate trends and implications for water resources in the Catskill Mountain region, New York: Journal of Hydrology, v. 366, p. 155-170. 
Campbell, J.L., Driscoll, C.T., Pourmokhtarian, Afshin, and Hayhoe, Katherine, 2011, Streamflow responses to past and projected future changes in climate at the Hubbard Brook Experimental Forest, New Hampshire, United States: Water Resources Research, v. 47, no. 2, W02514, 15 p., accessed September 2015 at https://doi.org/10.1029/2010WR009438.

Chase, K.J., 2011, Development of a precipitation-runoff model to simulate unregulated streamflow in the South Fork Flathead River Basin, Montana: U.S. Geological Survey Scientific Investigations Report 2011-5095, 38 p. [Also available at https://pubs.er.usgs.gov/publication/ sir20115095.]

Claessens, Luc, Hopkinson, Charles, Rastetter, Edward, and Vallino, Joseph, 2006, Effect of historical changes in land use and climate on the water budget of an urbanizing watershed: Water Resources Research, v. 42, no. 3, W03426, 13 p., accessed September 2015 at https://doi.org/10.1029/2005WR004131.

Clarke, L.E., Edmonds, J.A., Jacoby, H.D., Pitcher, H.M., Reilly, J.M., and Richels, R.G., 2007, Scenarios of greenhouse gas emissions and atmospheric concentrations: U.S. Climate Change Science Program Synthesis and Assessment Product 2.1A, 154 p. [Also available at https://downloads.globalchange.gov/sap/sap2-1a/ sap2-1a-final-all.pdf.]

Demaria, E.M.C., Palmer, R.N., and Roundy, J.K., 2016, Regional climate change projections of streamflow characteristics in the Northeast and Midwest U.S.: Journal of Hydrology, Regional Studies, v. 5, p. 309-323.

Di Vittoria, A.V., and Miller, N.L., 2014, Evaluating a modified point-based method to downscale cell-based climate variable data to high resolution grids: Lawrence Berkeley National Laboratory, accessed October 2015 at https://doi.org/10.1007/s00704-012-0740-9.

Dudley, R.W., and Hodgkins, G.A., 2013, Historical groundwater trends in northern New England and relations with streamflow and climatic variables: Journal of the American Water Resources Association, v. 49, no. 5, p. 1198-1212.

Dudley, R.W., and Nielsen, M.G., 2011, Simulation of streamflow in the Pleasant, Narraguagus, Sheepscot, and Royal Rivers, Maine, using watershed models: U.S. Geological Survey Scientific Investigations Report 2010-5221, 31 p., https://pubs.er.usgs.gov/publication/sir20105221.

Flanagan, S.M., Nielsen, M.G., Robinson, K.W., and Coles, J.F., 1999, Water-quality assessment of the New England Coastal Basins in Maine, Massachusetts, New Hampshire, and Rhode Island-Environmental settings and implications for water quality and aquatic biota: U.S. Geological Survey Water-Resources Investigations Report 98-4249, 64 p. [Also available at https://pubs.er.usgs.gov/publication/ wri984249.]
Groisman, P.Y., Knight, R.W., Easterling, D.R., Karl, T.R., Hegerl, T.C., and Razuvaev, V.N., 2005, Trends in intense precipitation in the climate record: Journal of Climate, v. 18, p. 1326-1350.

Hamilton, L.C., Keim, B.D., and Wake, C.P., 2010, Is New Hampshire's climate warming?: University of New Hampshire Carsey Institute New England Policy Brief 4, 8 p.

Hay, L.E., LaFontaine, J.H., and Markstrom S.L., 2014, Evaluation of statistically downscaled GCM output as input for hydrological and stream temperature simulation in the Apalachicola-Chattahoochee-Flint River Basin (19611999): Earth Interactions, v. 18, no. 9, 31 p.

Hay, L.E., Markstrom, S.L., Regan, R.S., and Viger, R.L., 2011, Watershed-scale response to climate change through the twenty-first century for selected basins across the United States: Earth Interactions, v. 15, issue 17, p. 1-37.

Hayhoe, Katharine, Wake, Cameron, Anderson, Bruce, Liang, Xin-Zhong, Maurer, Edwin, Zhu, Jinhong, Bradbury, James, DeGaetano, Art, Stoner, A.M., and Wuebbles, Donald, 2007, Regional climate change projections for the Northeast USA: Mitigation and Adaptation Strategies for Global Change, v. 13, nos. 5-6, p. 425-436.

Hayhoe, Katherine, Wake, C.P., Huntington, T.G., Luo, Lifeng, Schwartz, M.D., Sheffield, Justin, Wood, Eric, Anderson, Bruce, Bradbury, James, DeGaetano, Art, Troy, T.J., and Wolfe, David, 2006, Past and future changes in climate and hydrological indicators in the U.S. northeast: Climate Dynamics, v. 28, p. 381-407.

Hodgkins, G.A., and Dudley, R.W., 2011, Historical summer base flow and stormflow trends for New England rivers: Water Resources Research, v. 47, no. 7, W07528, 16 p., accessed October 15, 2017, at https://doi.org/10.1029/2010WR009109.

Hodgkins, G.A., Dudley, R.W., and Huntington, T.G., 2003, Changes in the timing of high river flows in New England over the 20th century: Journal of Hydrology, v. 278, p. 244-252.

Hyndman, R.J., and Koehler, A.B., 2006, Another look at measures of forecast accuracy: International Journal of Forecasting, v. 22, no. 4, p. 679-688.

Jacobs, Jennifer, Carignan, Brian, and Vuyovich, Carrie, 2014, Sustainable water in New Hampshire-The future of snow: New Hampshire Water and Watershed Conference, Plymouth, N.H., March 21, 2014, presentation, 35 slides, accessed November 28, 2017, at https://www.plymouth. edu/center-for-the-environment/files/2013/12/SustainableWater-in-New-Hampshire-The-Future-of-Snow_Jacobs.pdf. 
Karl, T.R., and Knight, R.W., 1998, Secular trend of precipitation amount, frequency, and intensity in the United States: Bulletin of the American Meteorological Society, v. 79, p. 231-242.

Koczot, K.M., Jeton, A.E., McGurk, B.J., and Dettinger, M.D., 2005, Precipitation-runoff processes in the Feather River Basin, northeastern California, and streamflow predictability, water years 1971-97: U.S. Geological Survey Scientific Investigations Report 2004-5202, 82 p. [Also available at https://pubs.er.usgs.gov/publication/sir20045202.]

LaFontaine, J.H., and Hay, L.E., 2013, The use of downscaled climate data in hydrologic and stream temperature models in the Apalachicola-Chattahoochee-Flint River Basin, southeastern USA: U.S. Geological Survey Open-File Report 2013-1278, $73 \mathrm{p}$.

LaFontaine, J.H., Hay, L.E., Viger, R.J., Markstrom, S.L., Regan, R.S., Elliott, C.M., and Jones, J.W., 2013, Application of the precipitation-runoff modeling system (PRMS) in the Apalachicola-Chattahoochee-Flint River Basin in the Southeastern United States: U.S. Geological Survey Scientific Investigations Report 2013-5162, 118 p., accessed August 2016 at https://pubs.er.usgs.gov/ publication/sir20135162.

LaFontaine, J.H., Hay, L.E., Viger, R.J., Regan, R.S., and Markstrom, S.L., 2015, Effects of climate and land cover on hydrology in the southeastern U.S.-Potential impacts on watershed planning: Journal of the American Water Resources Association, $27 \mathrm{p}$.

Leavesley, G.H., Lichty, R.W., Troutman, B.M., and Saindon, L.G., 1983, Precipitation-runoff modeling system; User's manual: U.S. Geological Survey Water-Resources Investigations Report 83-4238, 207 p. [Also available at https://pubs.er.usgs.gov/publication/wri834238.]

Mack, T.J., 2009, Assessment of ground-water resources in the Seacoast region of New Hampshire: U.S. Geological Survey Scientific Investigations Report 2008-5222, 188 p. [Also available at http://pubs.usgs.gov/sir/2008/5222.]

Markstrom, S.L., Regan, R.S., Hay, L.E., Viger, R.J., Webb, R.M.T., Payn, R.A., and LaFontaine, J.H., 2015, PRMS$\mathrm{IV}$, the precipitation-runoff modeling system, version 4 : U.S. Geological Survey Techniques and Methods, book 6, chap. B7, 158 p. [Also available at https://doi.org/10.3133/ tm6B7.]

Maurer, E.P., Wood, A.W., Adam, J.C., Lettenmaier, D.P., and Nijssen, Bart, 2002, A long-term hydrologically based dataset of land surface fluxes and states for the conterminous United States: Journal of Climate, v. 15, p. 3237-3251. [Data available at http://www.engr.scu.edu/ emaurer/gridded_obs/index_gridded_obs.html.]
Melillo, J.M., Richmond, T.C., and Yohe, G.W., eds., 2014: Climate change impacts in the United States-The third national climate assessment: U.S. Global Change Research Program, $841 \mathrm{p}$.

Miller, D.R., Ogden, F.L., Warner, G.S., and DeGaetano, A.T., 2002, Precipitation in Connecticut: Connecticut Institute of Water Resources Special Report 38, 65 p.

Milly, P.C.D., Betancourt, Julio, Falkenmark, Malin, Hirsch, R.M., Kundzewicz, Z.W., Lettenmaier, D.P., and Stouffer, R.J., 2008, Stationarity is dead-Whither water management?: Science, v. 319, no. 5863, p. 573-574.

Moriasi, D.N., Arnold, J.G., Van Liew, M.W., Bingner, R.L., Harmel, R.D., and Veith, T.L., 2007, Model evaluation guidelines for systematic quantification of accuracy in watershed simulations: Transactions of the American Society of Agriculture and Biology Engineers, v. 50, no. 3, p. 885-900.

Nakićenović, Nebojša, and Swart, Rob, eds., 2000, Emissions scenarios; A contribution of Working Group III on Mitigation: Intergovernmental Panel on Climate Change special report, $570 \mathrm{p}$. [Also available at http://www.ipcc.ch/ ipccreports/sres/emission/index.php?idp=0.]

Nash, J.E., and Sutcliffe, J.V., 1970, River flow forecasting through conceptual models; Part I-A discussion of principles: Journal of Hydrology, v. 10, no. 3, p. 282-290.

National Oceanic and Atmospheric Administration, Geophysical Fluid Dynamics Laboratory, 2016, Earth system models: National Oceanic and Atmospheric Administration models, accessed December 2016 at https://www.gfdl.noaa.gov/ earth-system-model/.

Neff, Rob, Chang, H.J., Knight, C.G., Najjar, R.G., Yarnal, Brent, and Walker, H.A., 2000, Impact of climate variation and change on mid-Atlantic region hydrology and water resources: Climate Research, v. 14, no. 3, p. 207-218.

New Hampshire Climate Change Policy Task Force, 2009, The New Hampshire climate action plan: New Hampshire Department of Environmental Sciences, March, 74 p., accessed January 2015 at https://www.des.nh.gov/ organization/divisions/air/tsb/tps/climate/action_plan/ documents/nhcap_final.pdf.

Oak Ridge National Laboratory, [undated], Daymet v3: Oak Ridge National Laboratory dataset, accessed August 2016 at http://daymet.ornl.gov/overview.

Oubeidillah, A.A., Kao, S.-C., Ashfaq, M., Naz, B.S., and Tootle, G., 2013, A large-scale, high-resolution hydrological model parameter data set for climate change impact assessment for the conterminous US: Hydrology Earth Systems Sciences, v. 10, p. 9575-9613, accessed October 2015 at https://doi.org/10.5194/hessd-10-9575-2013. 
Riahi, Keywan, Grübler, Arnulf, and Nakićenović, Nebojša, 2007, Scenarios of long-term socio-economic and environmental development under climate stabilization: Technology Forecasting and Social Change, v. 74, no. 7, p. 887-935.

Seaber, P.R., Kapinos, F.P., and Knapp, G.L., 1994: Hydrologic unit maps: U.S. Geological Survey Water-Supply Paper 2294, 63 p. [Also available at https://pubs.er.usgs. gov/publication/wsp2294.]

Smith, S.J., and Wigley, T.M.L., 2006, Multi-gas forcing stabilization with the MiniCAM: Energy Journal, v. SI3, p. 373-391.

Solomon, Susan, Qin, Dahe, Manning, Martin, Marquis, Melinda, Averyt, Kristen, Tignor, M.M.B., Miller, H.L., Jr., and Chen, Zhenlin, eds., 2007, Climate change 2007-The physical science basis: Intergovernmental Panel on Climate Change Fourth Assessment Report, 996 p. [Also available at https://www.ipcc.ch/publications_and_data/publications ipcc_fourth_assessment_report_wg1_report the_physical_ science_basis.htm.]

Stahl, K., Moore, R.D., Floyer, J.A., Asplin, M.G., and McKendry, I.G., 2006, Comparison of approaches for spatial interpolation of daily air temperature in a large region with complex topography and highly variable station density: Agricultural and Forest Meteorology, v. 139, nos. 3-4, p. 224-236.

Stocker, T.F., Qin, Dahe, Plattner, G.-K., Tignor, M.M.B., Allen, S.K., Boschung, Judith, Nauels, Alexander, Xia, Yu, Bex, Vincent, and Midgley, P.M., eds., 2013, Climate change 2013-The physical science basis: Intergovernmental Panel on Climate Change Fifth Assessment Report, 1535 p. [Also available at http://www.ipcc.ch/report/ar5/ $\operatorname{wg} 1 /$.

Thornton, P.E., Running, S.W., and White, M.A., 1997, Generating surfaces of daily meteorological variables over large regions of complex terrain: Journal of Hydrology, v. 190, no. 1997 , p. 214-251.

U.S. Department of Agriculture, 2008, Soil survey geographic database: U.S. Department of Agriculture data, accessed October 2008 at http://soils.usda.gov/survey/geography/ ssurgo/.

U.S. Department of Energy, Lawrence Livermore National Laboratory, 2006, CMIP3 - Coupled model intercomparison project phase 3: U.S. Department of Energy, Lawrence Livermore National Laboratory dataset, accessed December 2006 at http://cmip-pcmdi.llnl.gov/index.html.

U.S. Department of Energy, Lawrence Livermore National Laboratory, 2011, CMIP5 - Coupled model intercomparison project phase 5: U.S. Department of Energy, Lawrence Livermore National Laboratory dataset, accessed December 2011 at http://cmip-pcmdi.llnl.gov/index.html.
U.S. Geological Survey, 2008a, Elevation: U.S. Geological Survey The National Map data, accessed October 2008 at http://ned.usgs.gov/.

U.S. Geological Survey, 2008b, Hydrography: U.S. Geological Survey NHDPlus data, accessed October 2008 at http://nhd.usgs.gov/.

U.S. Geological Survey, 2008c, Land cover institute: U.S. Geological Survey web page, accessed October 2008 at http://landcover.usgs.gov/.

U.S. Geological Survey, 2016, National climate change viewer (NCCV) home: U.S. Geological Survey data, accessed August 2017 at http://www.usgs.gov/climate_landuse/ clu_rd/ncev.asp.

U.S. Geological Survey, 2017a, Precipitation runoff model system (PRMS): U.S. Geological Survey web page, accessed August 2017 at https://wwwbrr.cr.usgs.gov/ projects/SW_MoWS/PRMS.html.

U.S. Geological Survey, 2017b, USGS water data for the nation: U.S. Geological Survey National Water Information System data release, accessed August 2017 at https://doi.org/10.5066/F7P55KJN.

U.S. Geological Survey, [undated], Welcome to the USGS geo data portal: U.S. Geological Survey data, accessed October 2015 at https://cida.usgs.gov/gdp/.

Viger, R.J., 2014, Preliminary spatial parameters for PRMS based on the Geospatial Fabric, NLCD2001, and SSURGO: U.S. Geological Survey data release, accessed October 15, 2017, at https://doi.org/10.5066/F7WM1BF7.

Viger, R.J., and Bock, Andrew, 2014, GIS features of the Geospatial Fabric for national hydrologic modeling: U.S. Geological Survey data release, accessed October 15, 2017, at https://doi.org/10.5066/F7542KMD.

Viger, R.J., Hay, L.E., Jones, J.W., and Buell, G.R., 2010, Effects of including surface depressions in the application of the precipitation-runoff modeling system in the Upper Flint River Basin, Georgia: U.S. Geological Survey Scientific Investigations Report 2010-5062, 36 p. [Also available at https://pubs.er.usgs.gov/publication/sir20105062.]

Vogelmann, J.E., Howard, S.M., Yang, Limin, Larson, C.R., Wylie, B.K., and Van Driel, Nick, 2001, Completion of the 1990s national land cover data set for the conterminous United States from Landsat thematic mapper and ancillary data sources: Photogrammetric Engineering and Remote Sensing, v. 67, p. 650-662. [Also available at http://www.mrlc.gov/downloadfile2.php?file=Vogelmann. JE_PERS.67.2001_NLCD1992.pdf.] 
Wake, Cameron, Burakowski, Elizabeth, Hayhoe, Katharine, and Stoner, Anne, 2014a, Climate change in northern New Hampshire_-Past, present, and future: Durham, N.H., University of New Hampshire, 76 p. [Also available at https://sustainableunh.unh.edu/sites/sustainableunh.unh.edu/ files/images/northernnhclimateassessment2014.pdf.]

Wake, Cameron, Burakowski, Elizabeth, Hayhoe, Katharine, and Stoner, Anne, 2014b, Climate change in southern New Hampshire_-Past, present, and future: Durham, N.H., University of New Hampshire, 86 p. [Also available at https://sustainableunh.unh.edu/sites/sustainableunh.unh.edu/ files/images/southernnhclimateassessment2014.pdf.]

Wallace, J.M., and Hobbs, P.V., 1977, Atmospheric scienceAn introductory survey: New York, Academic Press, 467 p.
Wise, Marshall, Calvin, Katherine, Thomson, Allison, Clarke, Leon, Bond-Lamberty, Benjamin, Sands, Ronald, Smith, S.J., Janetos, Anthony, and Edmonds, James, 2009, Implications of limiting $\mathrm{CO}_{2}$ concentrations for land use and energy: Science, v. 324, issue 5931, p. 1183-1186.

Yukimoto, Seiji, Adachi, Yakimasa, Hosaka, Masahiro, Sakami, Tomonori, Yoshimura, Hiromasa, Hirabara, Makitoshi, Tanaka, T.Y., Shindo, Eiki, Tsujino, Hiroyuki, Deushi, Makoto, Mizuta, Ryo, Yabu, Shoukichi, Obata, Atsushi, Nakano, Hideyuki, Koshiro, Tsuyoshi, Ose, Tomoaki, and Kitoh, Akio, 2012, A new global climate model of the Meteorological Research Institute-MRICGCM3; Model description and basic performance: Journal of the Meteorological Society of Japan, v. 90A, p. 23-64. 


\section{Appendix 1. Evaluation of the Jensen-Haise Method of Estimating Potential Evapotranspiration in New England Using the Precipitation Runoff Modeling System}

\section{Introduction}

Modeling the land-surface water cycle, as is done in all watershed scale rainfall-runoff models, consists of three fundamental hydrologic processes - precipitation, evapotranspiration, and land-surface storage and runoff of water. The first two processes, precipitation and evapotranspiration, can be considered to be primarily driven by atmospheric conditions (although not entirely). The latter process is driven by conditions on the land surface and in the long term is the residual of the balance between precipitation and evapotranspiration. Generally, the precipitation process is determined by measured values and therefore is not subject to modeling or estimation, although distributing the measured values across the modeled watershed may be. Evapotranspiration in most cases is not measured; therefore, it is a simulated process that depends on measurements of other atmospheric and land-surface variables. Evapotranspiration is critical to understanding the water balance, thus the method used to simulate its value is key to the accuracy of the model.

The evapotranspiration process, as previously mentioned, is driven primarily by atmospheric conditions. More specifically, it is driven by atmospheric conditions near the ground and by the availability of water that can be evaporated or transpired (evapotranspiration). The water that is evapotranspired is collectively termed "actual evapotranspiration" (AET). In most watershed scale Precipitation Runoff models, including the U.S. Geological Survey Precipitation Runoff Modeling System (PRMS), the AET is simulated by first determining an evaporative demand, then determining how much water (soil water, open water, or water on open surfaces) is available to meet that demand. As such, the AET would equal the evapotranspirative demand unless the water available is less than the demand, in which case AET is less than the evapotranspirative demand.

The evapotranspirative demand is generally termed "potential evapotranspiration" (PET), which can be thought of as purely a function of atmospheric conditions or as a function of atmospheric conditions coupled with resistances to water movement offered by the soil and vegetation and the energy state of the stored water that is available for evapotranspiration. The atmospheric variables that drive PET are net energy inputs and mass transfer of water vapor away from the evapotranspirative surface. Methods used to estimate PET from temperature alone (such as the Hamon method; $\mathrm{Lu}$ and others, 2005) make the implicit assumption that there are general correlations between near surface air temperature and the temperature of the evaporating body and evaporation surface, the humidity, and the vapor pressure gradient. Generally, these methods ignore the effect of wind. The general relation between air temperature and the temperature of the evaporating body is probably consistent from one region to another, which is a reasonable assumption. However, in areas where shortwave solar radiation heats surfaces to temperatures significantly greater than the air temperature, greater evaporation rates can occur. Thus, inclusion of solar radiation in the PET relation can account for differences that result from solar radiation inputs to the near surface energy balance. Additionally, the general relation between air temperature, humidity, and vapor pressure gradient varies regionally and even within local areas, depending on the proximity to water bodies and elevation. Therefore, a method that includes relative humidity and (or) vapor pressure gradient data for the ground-level region would also be able to provide greater estimation accuracy on the basis of local conditions.

Past applications of the PRMS (Leavesley and others, 1983; Markstrom and others, 2015) typically employed the Jensen-Haise approach to modeling PET. In this appendix, two methods to estimate evapotranspiration are compared with the Jensen-Haise method. The key issue raised in a paper by Milly and Dunne (2011) indicates that successful hydrologic modeling of future conditions requires that the method for estimating PET not be unduly sensitive to changes in climate input variables, primarily air temperature.

At the scale of the hydrologic response unit (HRU), localized processes of heat transfer and convective/advective moisture transport will tend to balance. Also, the data necessary to assess the specific local conditions associated with advective transport generally would not be available. The data typically available from weather stations to model the evapotranspiration process include air temperature, humidity (or an estimate of dew point temperature), and solar radiation. Thus, it is clear that the methods to be assessed should include a representation of these three variables, preferably on a daily time step. These variables can also be obtained directly from downscaled general circulation model (GCM) output for any HRU and thus are ideal variables for use in the PET algorithm. The incident solar radiation at the surface in some cases may be difficult to obtain from weather stations as well as from GCMs because of a lack of data collection sites (in the case of weather stations) and poor representation of cloud cover dynamics (in the case of the GCMs). However, solar radiation can be estimated from calculated incoming solar radiation at the top of the atmosphere if cloud cover observations are available or from temperature and precipitation data (Markstrom and others, 2015). 


\section{Approach and Methods}

We evaluated the Jensen-Haise method used in PRMS by conducting a sensitivity study, along with the Penman method of estimating PET (Thom and Oliver, 1977; Fennessey and Vogel, 1996; Villa Nova and others, 2006). The comparison with Penman indicates how well Jensen-Haise compares with other more complete methods for the current climate over a specific time period, and the sensitivity of both methods to changing air temperature provides a means to test how the methods might respond to a changing climate.

The Penman method is considered to be one of the more complete physically based methods used in modeling applications (Allen and others, 1998). The Penman method requires daily incident solar radiation, outgoing longwave radiation, daily air temperature, daily wind speed, daily vapor pressure, and vapor pressure gradient. In comparison to the Penman method, the Jensen-Haise method can be viewed as somewhat simplified, requiring incident solar radiation, daily air temperature, and a climatic index to the vapor pressure, based on the saturation vapor pressures associated with the maximum and minimum air temperatures during the warmest month of the year.

\section{Penman Method}

The Penman method is a physically based approach to estimating evapotranspiration that combines the energy balance at the land surface with an aerodynamic term that accounts for mass transfer of water vapor away from the evaporating surface. The aerodynamic term is not dimensionally homogeneous and uses the empirical wind speed as a modifier to the vapor pressure deficit, which drives aerodynamic mixing. A recent form of the equation for evaporation (E) from Yates and Strzepek (1994), is used in this study, as follows:

$$
E=\left(\frac{\Delta}{\Delta+\gamma}\right)\left(R_{n}-G\right)+\left(\frac{\gamma}{\gamma+\Delta}\right) 15.36(1+0.0062 U)\left(e_{s}-e_{a}\right)
$$

where

$\Delta \quad$ is the slope of the saturation vapor pressure curve at the mean daily temperature $\left(T_{\text {mean }}\right)$, calculated by

$$
2,504 \frac{\exp \left(\frac{17.27 T_{\text {mean }}}{T_{\text {mean }}+273.3}\right)}{\left(T_{\text {mean }}+273.3\right)^{2}}
$$

$\gamma \quad$ is the psychrometric constant, equal to $0.000655 \mathrm{P}$,

$R_{n} \quad$ is net radiation calculated as the incident solar radiation $\left(R_{s}\right)$ at the surface minus the outgoing long wave radiation $\left(R_{l w}\right)$,

P calculated as $P=101.3\left(\frac{293-0.0065 z}{293}\right)^{5.26}$,

$z \quad$ is the weather station elevation,

$G \quad$ is the sensible heat flux to or from the ground,

$U \quad$ is the wind velocity at 2 meters above the evaporating surface, and

$\left(e_{s}-e_{a}\right) \quad$ is the vapor pressure deficit computed as the saturation vapor pressure at the mean daily air temperature minus the actual mean daily vapor pressure of the atmosphere above the evaporating surface.

Generally, this equation is not subject to calibration.

Evaporation $(E)$ is in units of radiation energy and can be converted to evaporated water equivalent by dividing by the latent heat (energy) of vaporization ( $\lambda$ ). It is important to keep the units consistent; the left term in equation 1-1 is in units of energy, and the right term mixes units of vapor pressure and velocity that must be converted to units of energy. The coefficient in equation 1-1 associated with the right term (15.36) provides the specific conversion, assuming that the units of energy are langleys and vapor pressure are millibars. The coefficient of the velocity variable in the right term is empirically derived and assumes that velocity is in 
kilometers per day. Units for $\Delta$ and $\gamma$ need to be the same, but because they occur as a ratio, the units do not need to be consistent with the other terms in equation 1-1.

The outgoing longwave radiation is computed from air temperature according to methods outlined in Environmental and Water Resources Institute (2005) and is given by the following equation:

$$
R_{l w}=4.903 \times 10^{-9}\left(T_{\text {mean }}+273\right)^{4}\left(0.34-0.14 e_{a}^{0.5}\right)\left[\frac{1.35 R_{s}}{\left(R_{a}(0.75+0.00002 h)\right)}\right]-0.35,
$$

where

$e_{a} \quad$ is the actual vapor pressure,

$R_{a} \quad$ is the extraterrestrial solar radiation, and

$h$ is the site elevation.

The sensible heat flux to or from the ground $(G)$ is computed for this study from temperature, assuming that air temperature is equivalent to surface ground temperature using the following equation:

$$
G=\frac{K_{t}\left(T_{\text {mean } i+1}-T_{\text {mean } i-1}\right)}{2},
$$

where
$K_{t} \quad$ is a conversion factor,
$i+1 \quad$ is the next day's temperature, and
$i-1 \quad$ is the previous day's temperature.

\section{Jensen-Haise Method}

The most commonly used PET module in PRMS is the Jensen-Haise method (Jensen and Haise, 1963; Leavesley and others, 1983; Igbadun and others, 2006). The method is semiempirical and uses mean near-surface air temperature and diurnal saturation vapor pressure differences (estimated from air temperature), elevation, and mean incident solar radiation. The mean incident solar radiation is calculated for latitude and day of the year and adjusted for atmospheric attenuation and reflectance (albedo) using a method based on precipitation and temperature. The variability of the daily evaporative demand is driven by the daily variation in average near-surface air temperature and the daily incident solar radiation. The Jensen-Haise method, as developed for PRMS, uses an average monthly maximum temperature index to compute the mean maximum and minimum saturation vapor pressures that are applied to the entire modeled area to account for climatic setting. The Jensen-Haise model is given by the following equations:

$$
\begin{gathered}
E=C_{t}\left(T_{\text {mean }}-T_{x}\right) R_{s} \\
C_{t}=\frac{1}{\left(68-\frac{h}{278}\right)+\left(\frac{650}{\left(e_{\text {smax }}-e_{\text {smin }}\right.}\right)} \\
T_{x}=\left(-27.5-0.25\left(e_{\text {smax }}-e_{\text {smin }}\right)-\frac{h}{1,000}\right)
\end{gathered}
$$

where

$$
\begin{aligned}
& E \text { and } R_{s} \quad \text { are potential water evaporation, } \\
& C_{\mathrm{t}} \text { and } T_{\mathrm{x}}^{s} \text { are coefficients, } \\
& T_{\text {mean }} \quad \text { is the mean daily temperature, calculated by the average of maximum and } \\
& \text { minimum daily air temperatures, } \\
& h \text { is the mean elevation of the representative station (or in the case of the model, } \\
& \text { the hydrologic response unit), and }
\end{aligned}
$$


$\left(e_{\operatorname{smax}}-e_{\operatorname{smin}}\right) \quad$ is the saturation vapor pressure deficit between the daily maximum and the daily minimum temperatures for the warmest month of the year.

The vapor pressure function is an index for the actual vapor pressure deficit and is used in lieu of input data for relative humidity or dew point temperature. Given that all coefficients used in the model are calculated directly, the model does not require calibration in the form presented in this study. However, in the original form of the method, the coefficients were not precisely defined and thus are subject to calibration. Therefore, the coefficients of the Jensen-Haise model $\left(C_{t}\right.$ and $\left.T_{x}\right)$ are considered to be primarily empirical in nature and thus subject to calibration. In this study, we did not use any calibration; therefore, the method was evaluated as presented.

\section{Data and Data Requirements}

The data needed to estimate PET using the methods outlined previously include incident solar radiation, air temperature, vapor pressure deficit (calculated from dew point temperature or relative humidity), station elevation, station latitude, and wind velocity. All of these data are available from some weather stations but are not available from most stations. Typically, weather stations report precipitation and air temperature along with elevation, latitude, and longitude. Cloud cover, as a percentage of the clear sky, is also available from some stations. The extent to which all of these data can be used improves the coverage of information necessary to estimate PET over large areas. Comparison of the different methods provides insight into the key variables that are necessary to calculate a reasonable value for PET. Cloud cover and precipitation can be used to estimate incident solar radiation from calculated extraterrestrial radiation where measured incident solar radiation is not available.

For this study, data were acquired from the Northeast Regional Climate Center (undated). Datasets were selected to provide the data necessary to evaluate the methods described above and to provide independent estimates of PET, either calculated or from pan evaporation. The datasets were not quality controlled as part of this study; thus, the data were used directly under the assumption that they are quality controlled at the source. This is generally true of the Northeast Regional Climate Center (NRCC) data (DeGaetano and others, 1994).

\section{Independently Estimated PET}

Some weather stations report an independently estimated value for PET or AET. These estimates are based on the weather data collected at the site and may use directly measured solar radiation or estimated solar radiation determined from cloud cover and calculated extraterrestrial solar radiation. The estimates of PET reported by the NRCC were determined using a calibrated Penman-Monteith method (DeGaetano and others, 1994). The estimates are calibrated to individual stations and therefore include site specific information about the surroundings, including cover characteristics and setting. As such, these data are considered more accurate for the individual station than the estimates developed for a model application that computes a generalized PET for the region being modeled.

\section{Solar Radiation}

The pertinent solar radiation data consist of the incident shortwave radiation and the net longwave radiation (the longwave out and the longwave reflected back or absorbed and radiated back to Earth from clouds and other greenhouse gases). These radiation quantities are generally estimated or calculated from a calculated value of the extraterrestrial radiation (incoming radiation at the top of the atmosphere) and from weather variables, including air temperature, precipitation, and humidity, and cloud cover. Some locations measure incident solar radiation. Longwave radiation is not measured and must be estimated from the temperature. Values used here are obtained from the NRCC (DeGaetano and others, 1993).

\section{Temperature and Precipitation}

Near-surface air temperatures, including maximum, minimum, and average daily values, and daily precipitation totals are widely available from numerous sources and therefore provide the foundation for input data to watershed models. Given the close relation between minimum air temperature and the dew point temperature, the minimum temperature may be used in lieu of dew point temperature to calculate actual vapor pressure. With this recommendation, the Penman based equation can be used for comparison to the Jensen-Haise method of estimating PET. In addition, the relation of minimum air temperature to dew point temperature indicates the basis of validity for its application in the Jensen-Haise method.

\section{Wind}

Wind speed is available from many weather stations across the country but generally is not available for regional coverage from the National Oceanographic and Atmospheric Administration Cooperative Observer Program stations. Additionally, wind is generally not available from gridded weather datasets for the continental United States or from GCM output obtained through the Geo Data Portal (U.S. Geological Survey, undated). Consequently, wind speed is not generally available for regional modeling. Wind may be an important factor in local evapotranspiration. It is not clear how important wind is on larger scales, as would be the case if estimating PET for an HRU that is 10 or 20 square miles in area, for example. To test the importance of wind, three key questions are addressed in this analysis. What is the average wind speed for this area? What role does it play in the mass transfer of moisture at that scale? How important is wind in the PET estimates? 


\section{Comparison of Methods}

The calculation of the slope of the saturation vapor pressure curve, the vapor pressure gradient, the longwave radiation, and the sensible heat flux are all dependent on temperature; by inspection of equations $1-1$ and $1-4$, it is evident that the Penman and Jensen-Haise methods rely on air temperature and solar radiation to estimate PET. The Penman method also accounts for wind speed, sensible heat flux to or from the ground, and net longwave radiation. Thus, the differences between the two methods are a function of the magnitude and arrangement of the modifiers. We would expect that the methods would predict similar PET values, given similar temperature and solar radiation inputs. The key question is whether the two methods produce linear or nonlinear estimates relative to each other over the range of temperature values expected in future climate scenarios. Assuming incident solar radiation does not change appreciably in the future climate, the change in air temperature over the 21 st century is expected to range from 4 to 8 degrees Fahrenheit $\left({ }^{\circ} \mathrm{F}\right)$ in New England with minimum daily air temperature changing at a different rate than maximum daily air temperature (Bjerklie and others, 2015; Wake and others, 2014).

Input datasets were compiled for the Lebanon and the Mount Washington weather stations in New Hampshire for comparison (Northeast Regional Climate Center, undated). PET estimates for 2 years from the Penman and Jensen-Haise methods were compared with PET estimates from the Northeast Regional Climate Center for the same weather stations. Neither the Penman nor Jensen-Haise estimates were calibrated. The Jensen-Haise method tends to produce the most accurate estimates compared to independent estimates. JensenHaise consistently estimated values lower than the Penman based methods (figs. 1-1 and 1-2). The Jensen-Haise method can produce negative values when temperature is below freezing. When water is frozen, evaporation occurs by sublimation, and neither the Penman nor the Jensen-Haise method models the sublimation process, which is much slower than evaporation from an open water surface. Although Jensen-Haise may produce negative values of PET when temperatures are below freezing, Penman typically will produce a positive value when the temperature is below freezing. In either case the PET estimate for temperatures below freezing are either unrealistic or at least methodologically suspect and have been removed from the record analyzed in this appendix. In PRMS, evapotranspiration is assumed to be zero if PET is negative and generally is not considered to be operating when leaves are off the trees during the cold winter months.

Figures 1-3 through 1-6 show the estimated PET from Penman and Jensen-Haise methods, and the NRCC method using measured data, in relation to the input variables of incident solar radiation and average daily air temperature in order to evaluate the relative importance of these two variables. Solar radiation is more highly correlated with PET than air temperature at both weather stations. The relations for the three methods are similar with Jensen-Haise method resulting in nearly the same relation for the two variables as the NRCC method.

As stated previously, the Penman method accounts for the effects of wind and sensible heat loss or gain from the ground. The national gridded input weather datasets accessed for the PRMS modeling in this report do not include wind or ground temperatures, thus these contributions to PET could not be modeled by Penman or any other method. Therefore, the Jensen-Haise method does not fall short in this regard. However, as part of this sensitivity analysis, wind and an estimate of the sensible heat flux to the ground, based on air temperature in the Penman method, were included for comparison. At both the Mount Washington and Lebanon stations, wind is nearly always present. The wind speed averages 3.8 miles per hour at Mount Washington and 4.5 miles per hour at Lebanon. Inclusion of wind in the PET estimates made using Penman resulted in an increase of the mean PET by 12 percent at Mount Washington and 17 percent at Lebanon; the standard deviations of PET increased by 6 and 9 percent, at the Mount Washington and Lebanon stations, respectively. Inclusion of sensible heat flux resulted in negligible change. Although this would indicate that wind is an important contributor to PET, because Penman tended to overpredict the measured values at both stations even without the inclusion of wind, it would seem that there would be no imperative to include wind. Also, because the effects of wind at the station scale are difficult to compare to the effects of wind at the PRMS HRU scale as a result of the highly variable nature of wind in varied terrain, the exclusion of wind in Jensen-Haise method is not considered to be a substantial limitation for the PET estimates in PRMS.

\section{Climate Change Sensitivity Analysis}

The sensitivity of the Penman and Jensen-Haise methods was tested by increasing the maximum and minimum daily air temperatures that are input to the estimates. Two mean temperature change datasets were tested: a dataset where the mean value of random change in the temperature data is increased by $4{ }^{\circ} \mathrm{F}$ for the maximum daily and $5^{\circ} \mathrm{F}$ for the minimum daily and a dataset where the mean value of random change in the temperature data is increased by $7^{\circ} \mathrm{F}$ for the maximum daily and $8^{\circ} \mathrm{F}$ for minimum daily. The two methods responded consistently and similarly (figs. 1-7 through 1-12). In these figures, the Jensen-Haise estimate is plotted against the Penman estimate, and the slope of the relation is evaluated. The character of the relation between the two methods remains consistent, including similar slope, intercept, and spread of the points, indicating that the changing air temperature does not alter the comparative predictive qualities of the methods. This is likely because temperature is controlling the vapor pressure gradient, and if the maximum and minimum temperatures vary similarly, the vapor pressure difference is not radically altered. Assuming that solar radiation is adequately simulated for future conditions, the two methods likely respond to the changing climate similarly and therefore can be expected to be stable in a future simulation. 


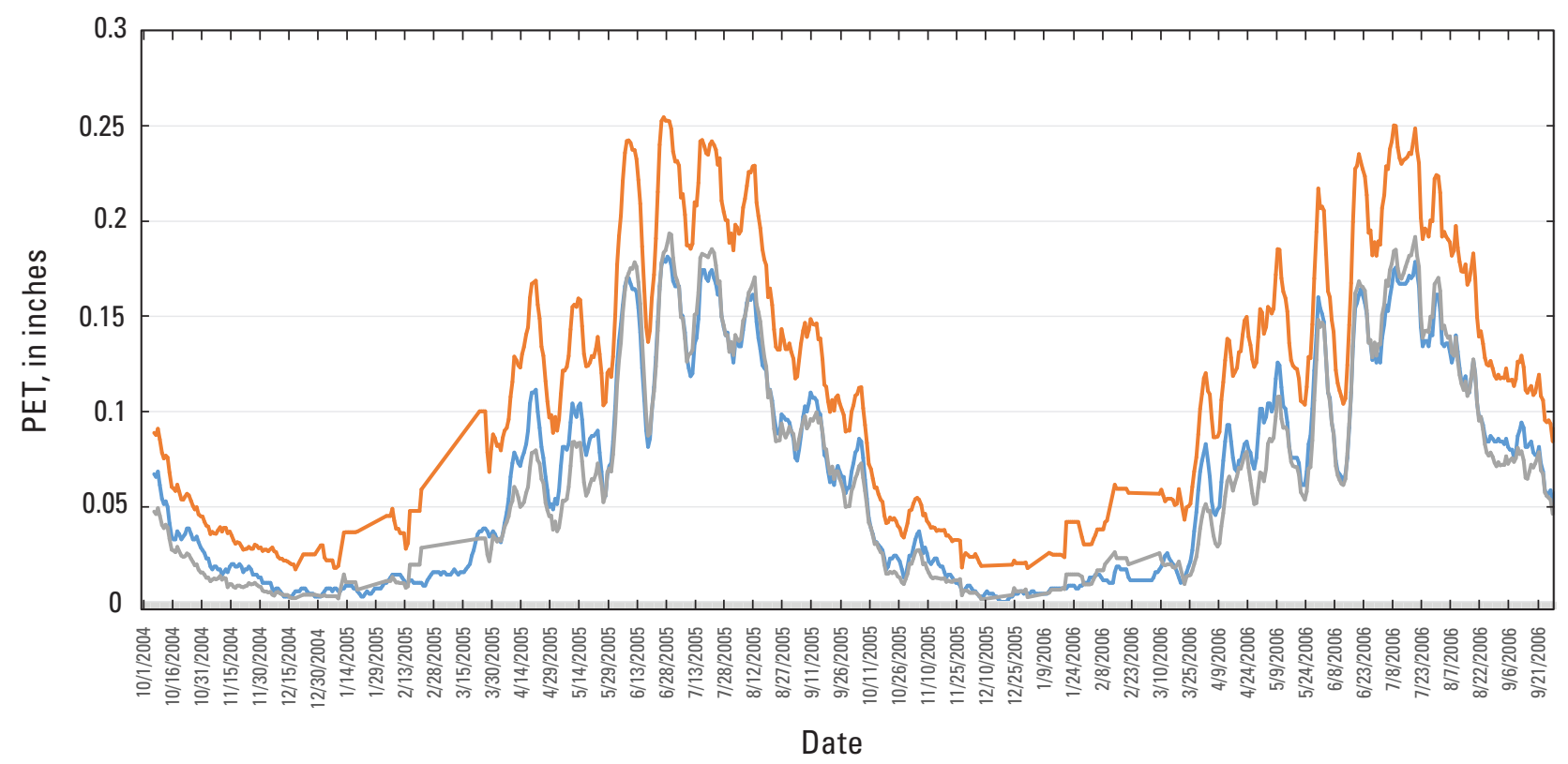

EXPLANATION

Moving average of potential evapotranspiration

7-day moving average, NRCC PET — 7 percent, Jensen-Haise method

- 7 percent, Penman method

Figure 1-1. Time series of 2 years of estimated potential evapotranspiration for the Mount Washington weather station in New Hampshire using Northeast Regional Climate Center measured data and Penman and Jensen-Haise methods with a 7-day moving average. NRCC, Northeast Regional Climate Center; PET, potential evapotranspiration.

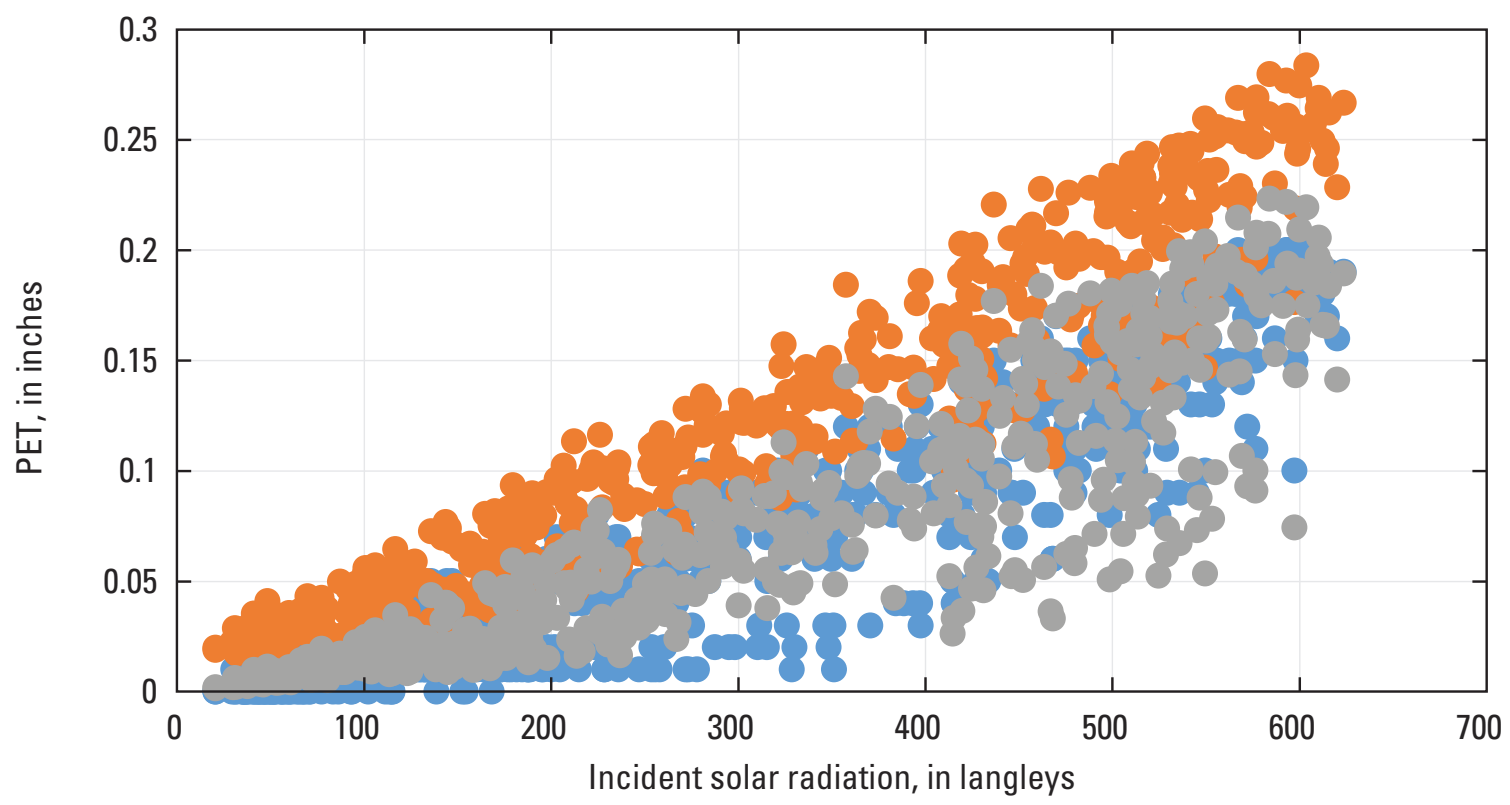

\section{EXPLANATION}

NRCC PET

Penman method Jensen-Haise method

Figure 1-2. Time series of 2 years of estimated potential evapotranspiration for the Lebanon weather station in New Hampshire from the Northeast Regional Climate Center measured data and Penman and JensenHaise methods with the 7-day moving average. NCRR, Northeast Regional Climate Center; PET, potential evapotranspiration. 


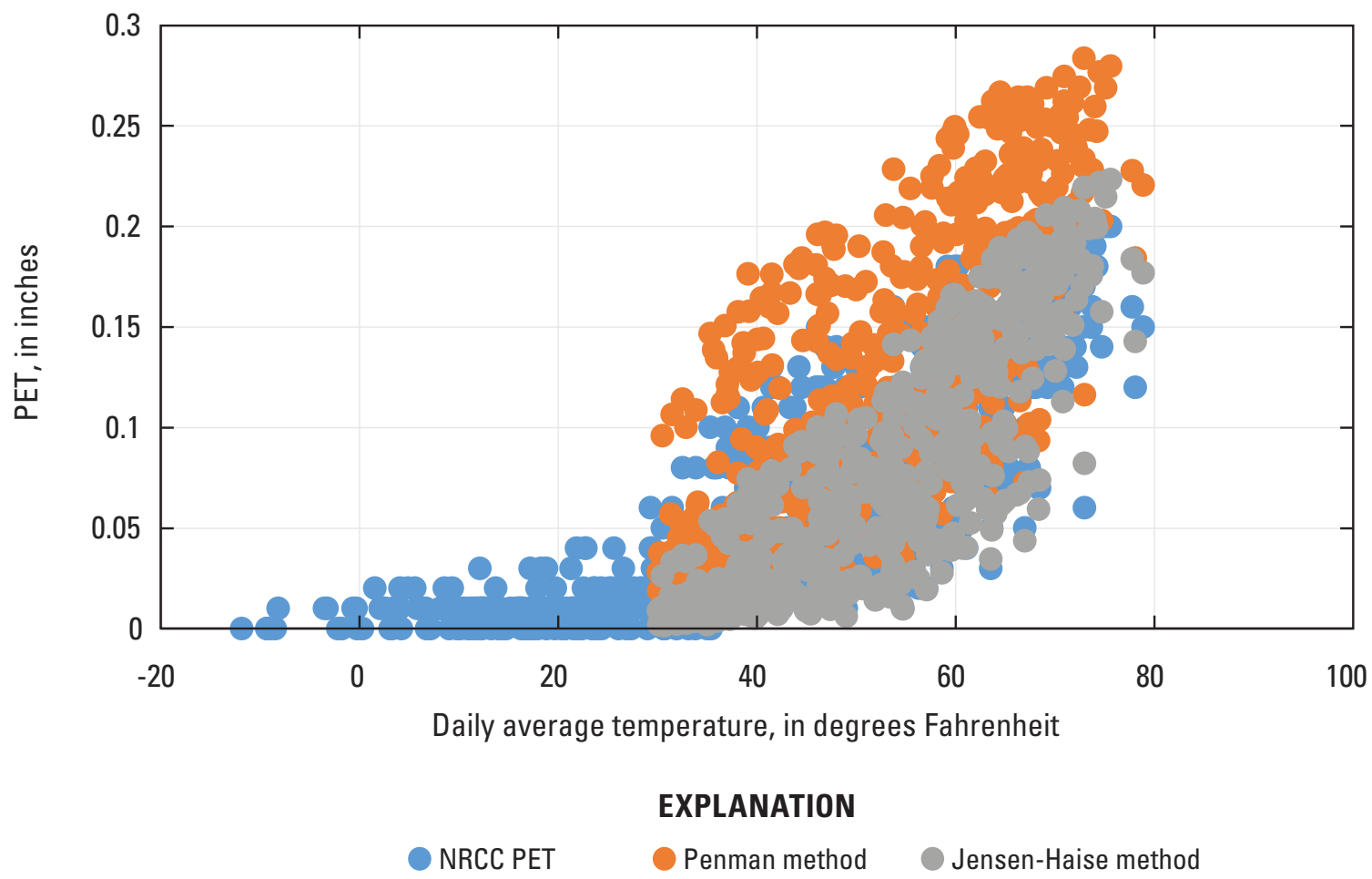

Figure 1-3. Estimated daily potential evapotranspiration using Northeast Regional Climate Center method with measured data and Penman and Jensen-Haise methods in relation to average daily incident solar radiation for the Mount Washington, New Hampshire, weather station. NCRR, Northeast Regional Climate Center; PET, potentiometric evapotranspiration.

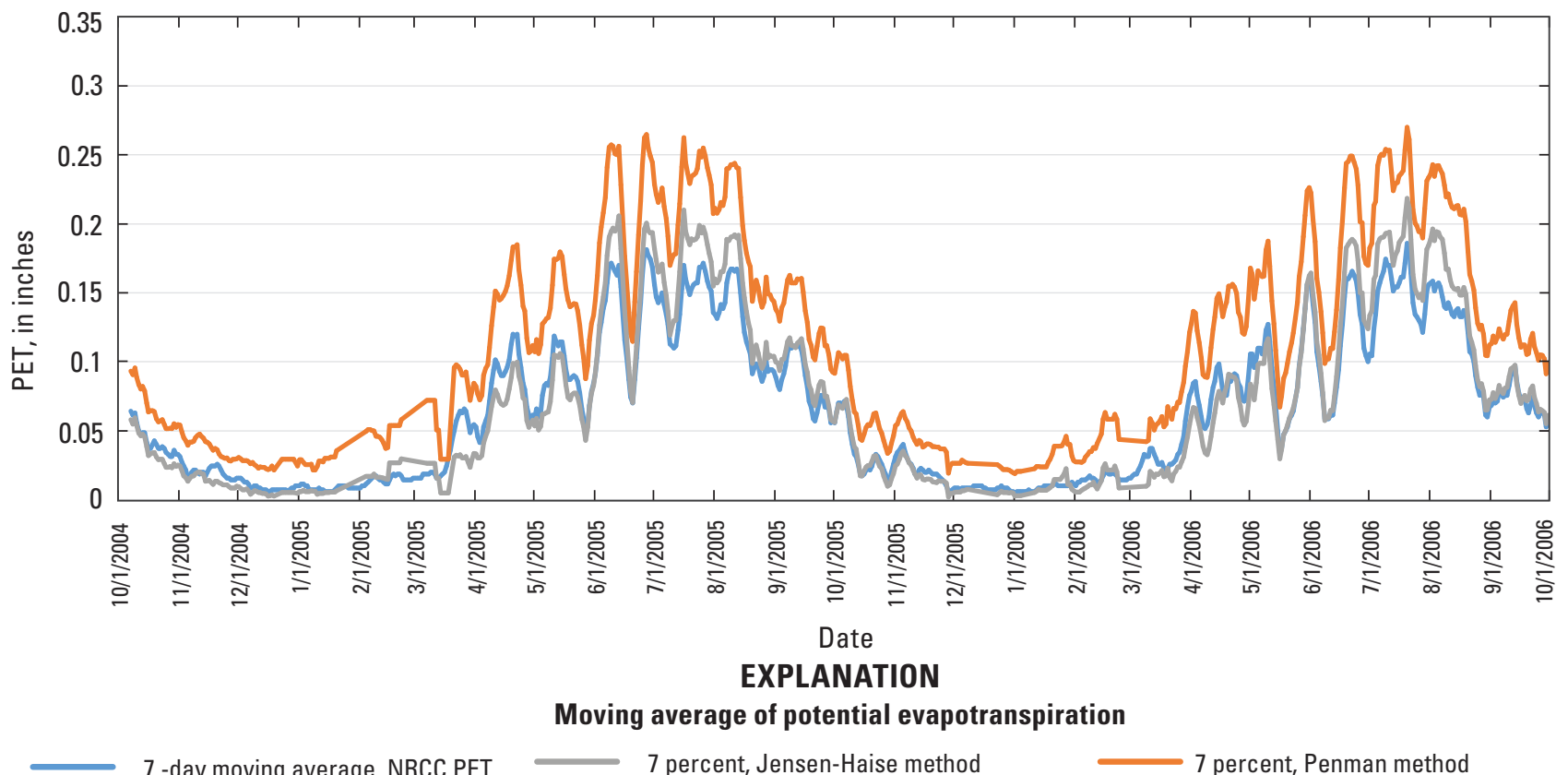

Figure 1-4. Estimated daily potential evapotranspiration using Northeast Regional Climate Center method with measured data and Penman and Jensen-Haise methods in relation to daily average air temperature for the Mount Washington, New Hampshire, weather station. NCRR, Northeast Regional Climate Center; PET, potentiometric evapotranspiration. 


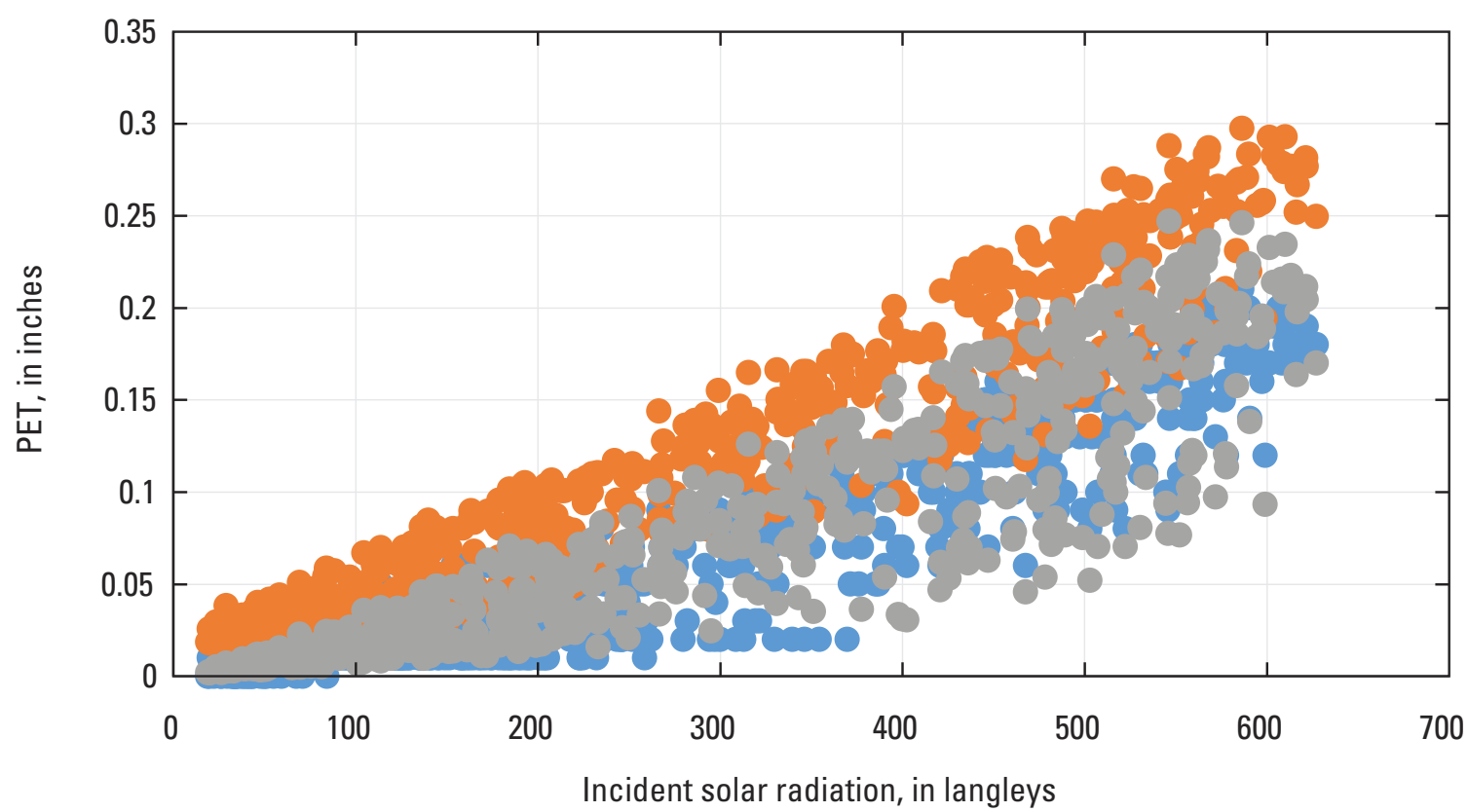

\section{EXPLANATION}

NRCC PET Penman method Jensen-Haise method

Figure 1-5. Estimated daily potential evapotranspiration using Northeast Regional Climate Center method with measured data and Penman and Jensen-Haise methods in relation to average daily incident solar radiation for the Lebanon, New Hampshire, weather station. NCRR, Northeast Regional Climate Center; PET, potential evapotranspiration.

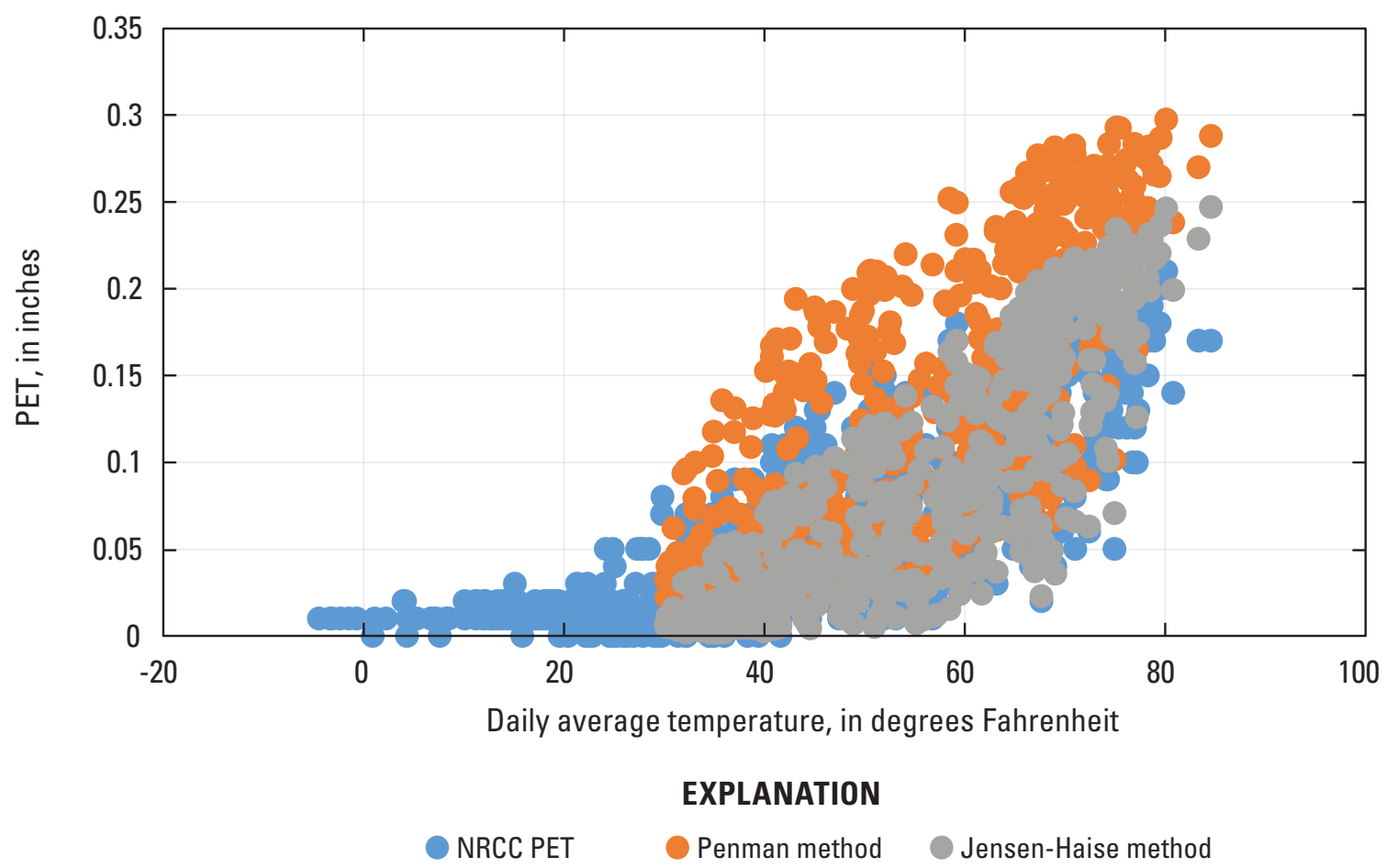

Figure 1-6. Estimated daily potential evapotranspiration using Northeast Regional Climate Center method with measured data and Penman and Jensen-Haise methods in relation to daily average air temperature for the Lebanon, New Hampshire, weather station. NCRR, Northeast Regional Climate Center; PET, potential evapotranspiration. 


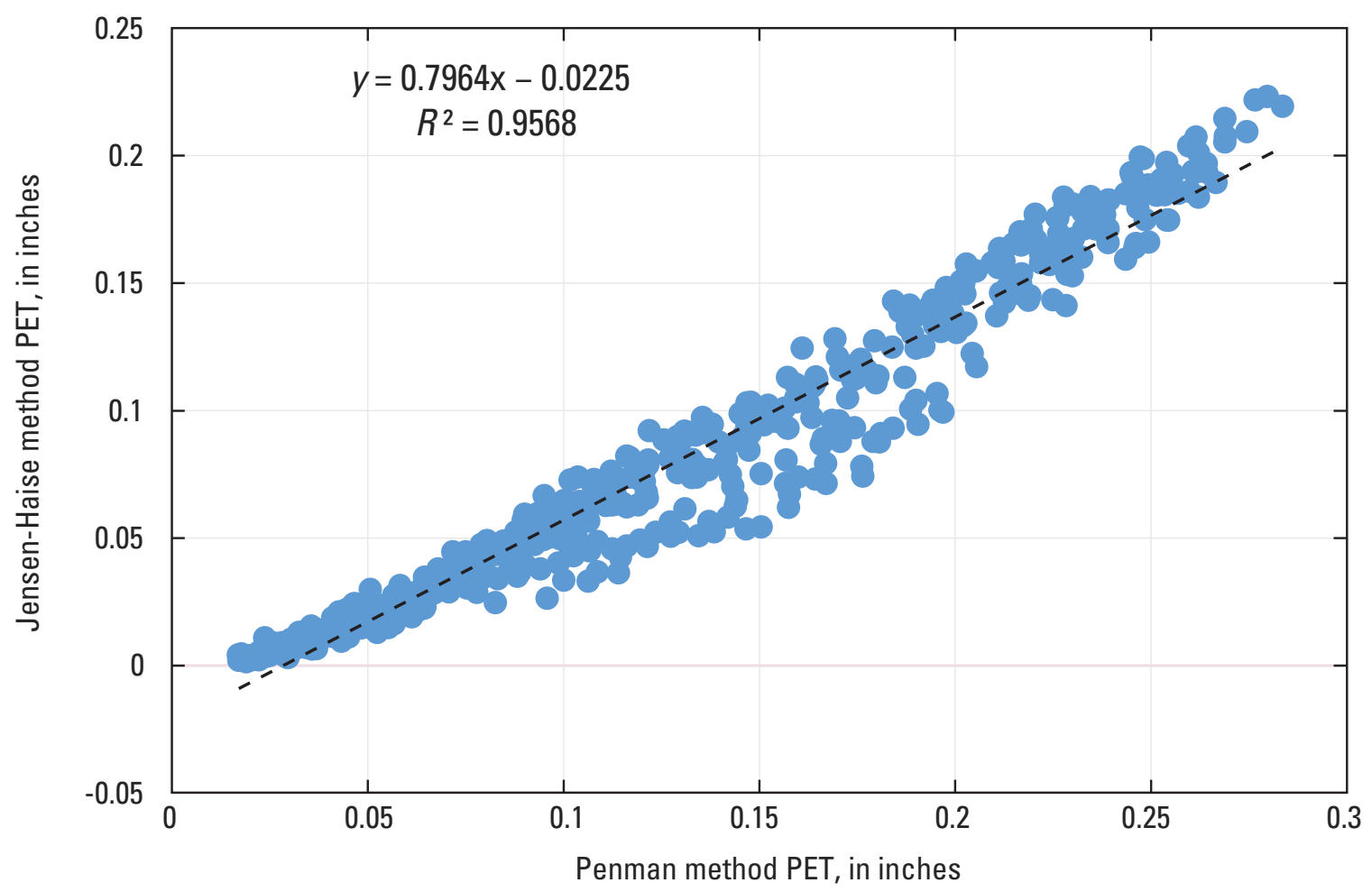

Figure 1-7. Estimated daily potential evapotranspiration for a 2-year period using Jensen-Haise method in relation to estimates using the Penman method for the Mount Washington weather station in New Hampshire with the best fit linear correlation with slope and intercept. PET, potential evapotranspiration.

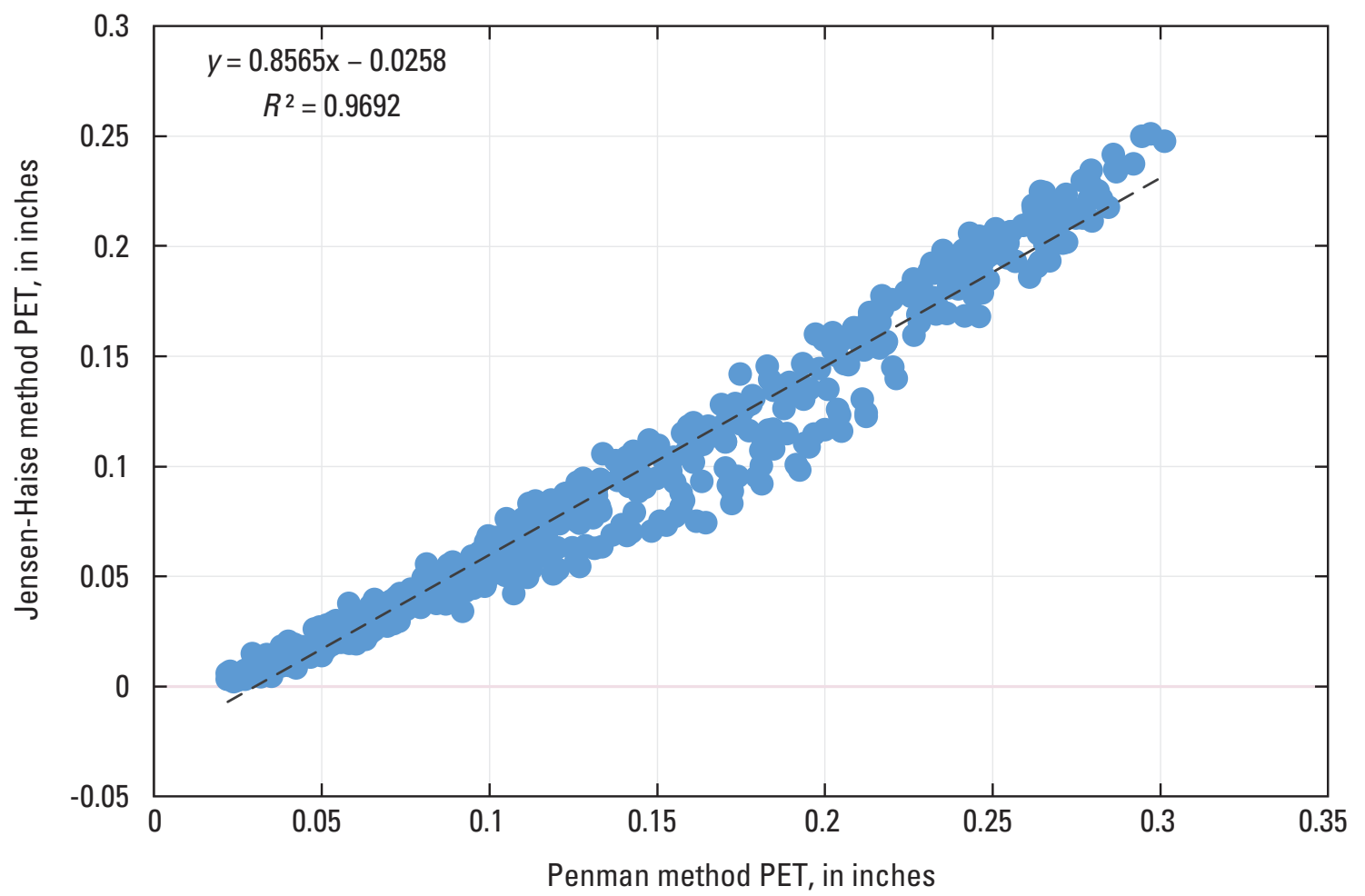

Figure 1-8. Estimated daily potential evapotranspiration for a 2-year period using Jensen-Haise method in relation to estimates using the Penman method for the Mount Washington weather station in New Hampshire with the best fit linear correlation with slope and intercept after adjusting the mean maximum daily temperature by 4 degrees Fahrenheit and the minimum by 5 degrees Fahrenheit. PET, potential evapotranspiration. 


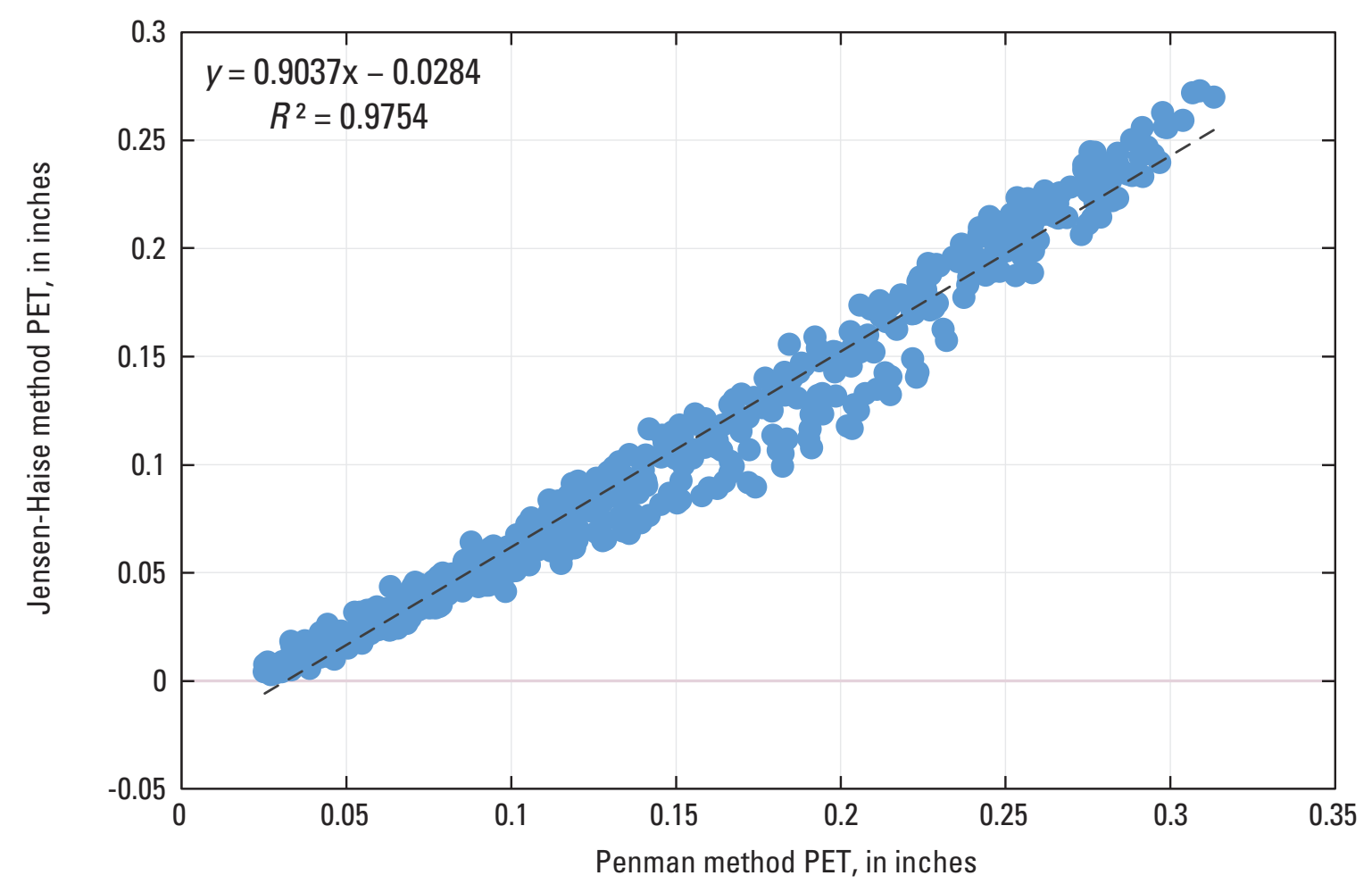

Figure 1-9. Estimated daily potential evapotranspiration for a 2-year period using Jensen-Haise method in relation to estimates using the Penman method for the Mount Washington weather station in New Hampshire with the best fit linear correlation with slope and intercept after adjusting the mean maximum daily temperature by 7 degrees Fahrenheit and the minimum by 8 degrees Fahrenheit. PET, potential evapotranspiration.

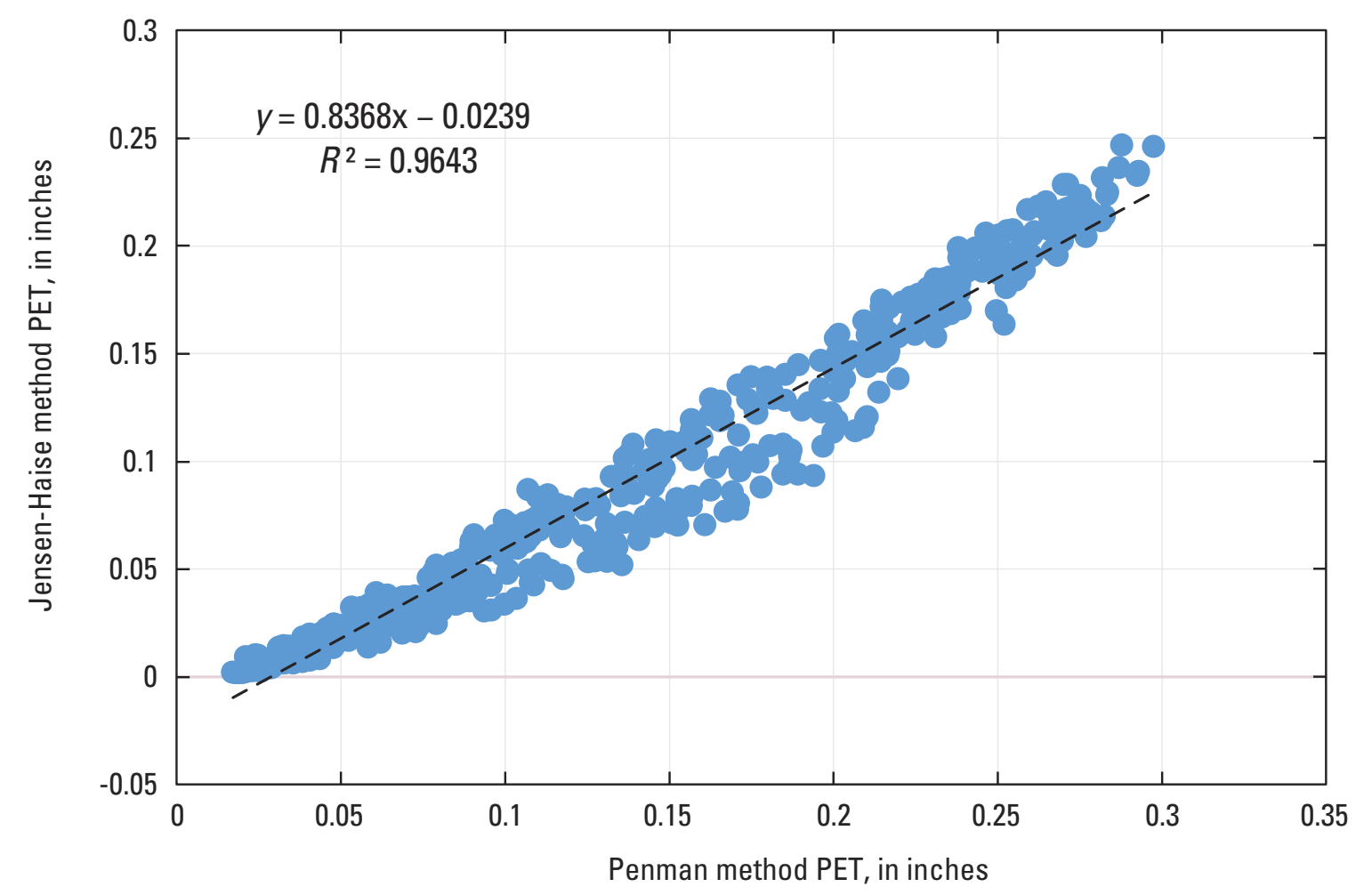

Figure 1-10. Estimated daily potential evapotranspiration for a 2-year period using the Jensen-Haise method in relation to estimates using the Penman method for the Lebanon weather station in New Hampshire with the best fit linear correlation with slope and intercept. PET, potential evapotranspiration. 


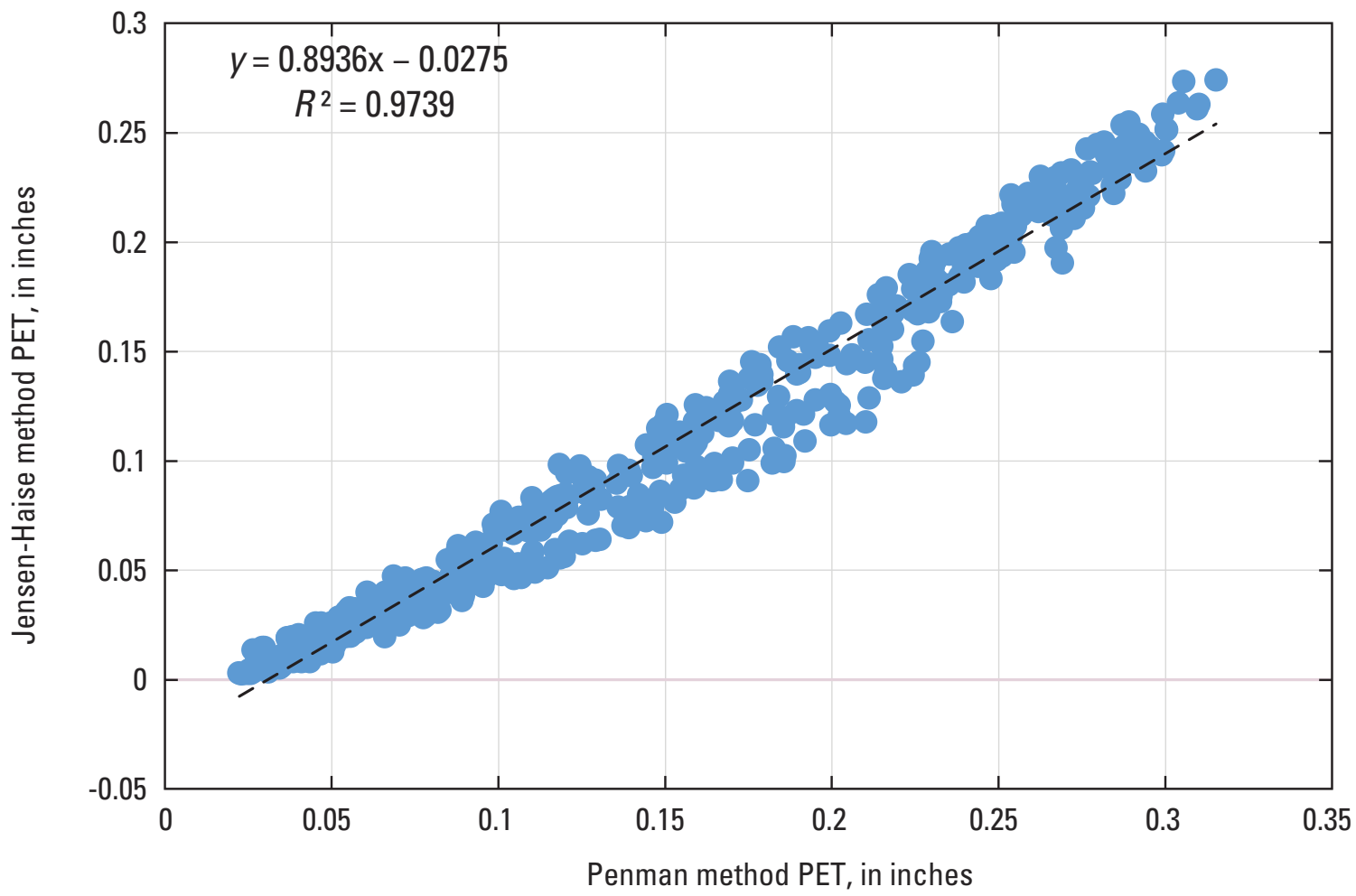

Figure 1-11. Estimated daily potential evapotranspiration for a 2-year period using the Jensen-Haise method in relation to estimates using the Penman method for the Lebanon weather station in New Hampshire with the best fit linear correlation with slope and intercept after adjusting the mean maximum daily temperature by 4 degrees Fahrenheit and the minimum by 5 degrees Fahrenheit. PET, potential evapotranspiration.

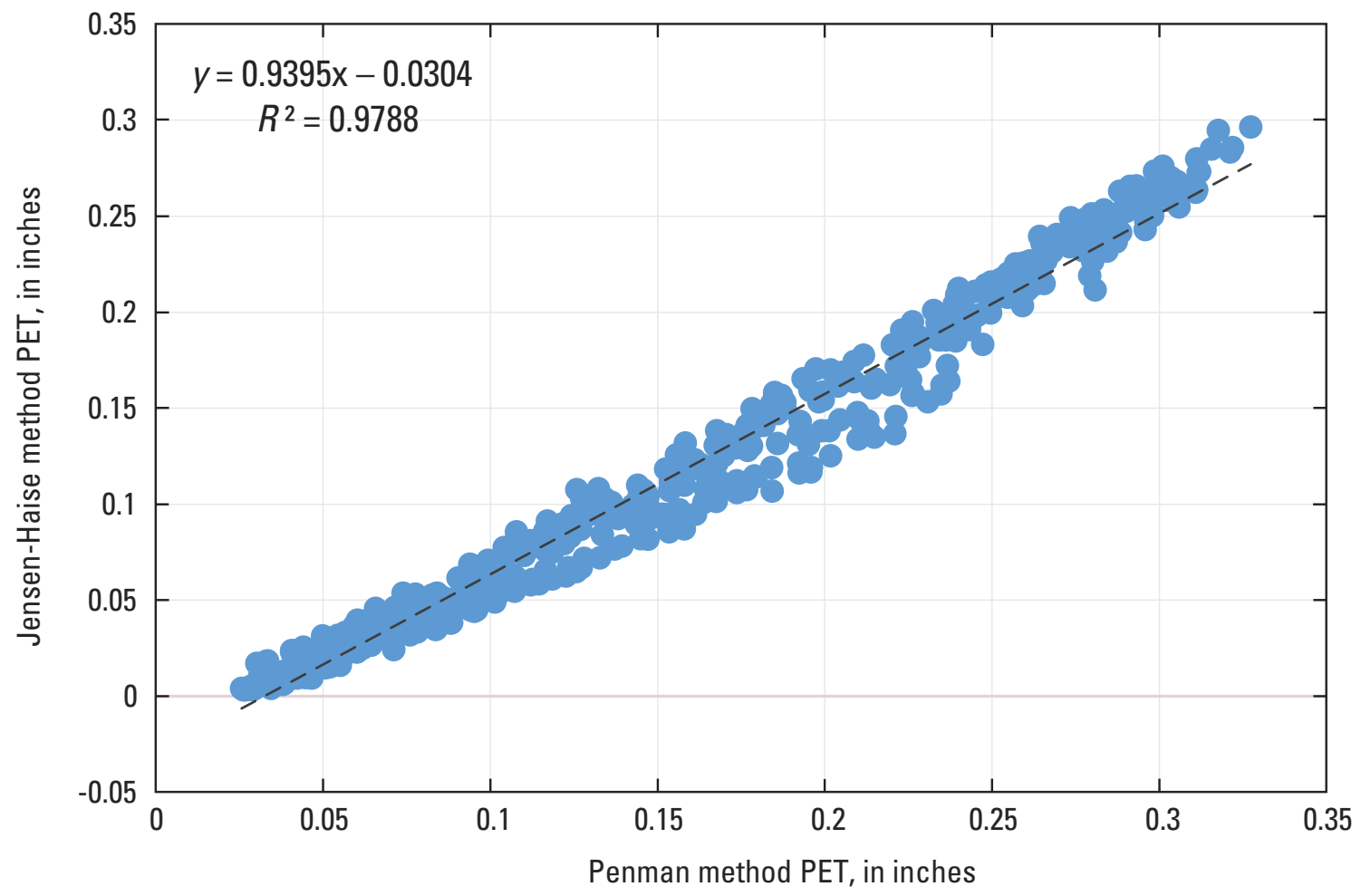

Figure 1-12. Estimated daily potential evapotranspiration for a 2-year period using the Jensen-Haise method in relation to estimates using the Penman method for the Lebanon weather station in New Hampshire with the best fit linear correlation with slope and intercept after adjusting the mean maximum daily temperature by 7 degrees Fahrenheit and the minimum by 8 degrees Fahrenheit. PET, potential evapotranspiration. 


\section{Summary}

The sensitivity of the Jensen-Haise method potential evapotranspiration (PET) algorithm used in the PRMS model to changes in temperature were tested by comparison of those PET estimates with the best estimates of PET from weather station data and with estimates from the Penman PET algorithm. On the basis of these comparisons, the Jensen-Haise method is expected to provide changes in air temperature comparable in magnitude and response to those from the Penman method. We conclude that over the range of expected climate change addressed in this study, the Jensen-Haise method for estimating PET provides results similar to those from the more physically based Penman method. The Penman method includes the effects of wind and sensible heat exchange with the Earth, which Jensen-Haise method does not. Including wind in the PET estimates tends to increase the PET estimate for the weather station, and inclusion of sensible heat flux to the ground tends to decrease the PET. Neither wind nor sensible heat flux information is readily available as input to regional watershed runoff models, so inclusion of these data is not practical. Consequently, the Jenson-Haise method is considered appropriate for application to future climate modeling because its equation reduces to an equation similar to that of Penman, if wind and sensible heat flux are ignored.

\section{Selected References}

Allen, R.G., Pereira, L.S., Raes, Dirk, and Smith, Martin, 1998, Crop evapotranspiration-Guidelines for computing crop water requirements: Rome, Food and Agriculture Organization of the United Nations Irrigation and Drainage Paper 56, $174 \mathrm{p}$.

Bjerklie, D.M., Ayotte, J.D., and Cahillane, M.J., 2015, Simulating hydrologic response to climate change scenarios in four selected watersheds of New Hampshire: U.S. Geological Survey Scientific Investigations Report 2015-5047, 53 p. [Also available at https://doi.org/10.3133/ sir20155047.]

DeGaetano, A.T., Eggleston, K.L., and Knapp, W.W., 1993, Daily solar radiation estimates for the Northeastern United States: Northeast Regional Climate Center Publication RR 93-4, 7 p.

DeGaetano, A.T., Eggleston, K.L., and Knapp, W.W., 1994, Daily evapotranspiration and soil moisture estimates for the northeastern United States: Northeast Regional Climate Center Publication RR 94-1, 11 p.

Environmental and Water Resources Institute, 2005, The ASCE-EWRI standardized reference evapotranspiration equation: American Society of Civil Engineers, 59 p., accessed September 2015 at https://www.kimberly.uidaho. edu/water/asceewri/ascestzdetmain2005.pdf.
Fennessey, N.M., and Vogel, R.M., 1996, Regional models of potential evaporation and reference ET for the northeast USA: Journal of Hydrology, v. 184, p. 337-354.

Igbadun, H.E., Mahoo, H.F., Tarimo, A.K.P.R., and Salim, B.S., 2006, Performance of two temperature-based reference evapotranspiration models in the Mkoji sub-catchment in Tanzania: Agricultural Engineering International, v. VIII, LW 05008,19 p.

Jensen, M.E., and Haise, H.R., 1963, Estimating evapotranspiration from solar radiation: Journal of Irrigation and Drainage Engineering, v. 96, no. 1, p. 25-38.

Leavesley, G.H., Lichty, R.W., Troutman, B.M., and Saindon, L.G., 1983, Precipitation-runoff modeling system; User's manual: U.S. Geological Survey Water-Resources Investigations Report 83-4238, 207 p. [Also available at https://pubs.er.usgs.gov/publication/wri834238.]

Lu, Jianbiao, Ge Sun, McNulty, S.G., and Amtaya, D.M., 2005, A comparison of six potential evapotranspiration methods for regional use in the southeastern United States: Journal of the American Water Resources Association, v. 41, no. 3, p. 621-633.

Markstrom, S.L., Regan, R.S., Hay, L.E., Viger, R.J., Webb, R.M.T., Payn, R.A., and LaFontaine, J.H., 2015, PRMS-IV, the precipitation-runoff modeling system, version 4: U.S. Geological Survey Techniques and Methods, book 6, chap. B7, 158 p., accessed September 2015 at https://doi.org/10.3133/tm6B7.

Milly, P.C.D., and Dunne, K.A., 2011, On the hydrologic adjustment of climate-model projections-The potential pitfall of potential evapotranspiration: Earth Interactions, v. 15 , no. 1,15 p.

New Hampshire Climate Change Policy Task Force, 2009, The New Hampshire climate action plan-A plan for New Hampshire's energy, environmental, and economic development future: Concord, N.H., New Hampshire Department of Environmental Services, 74 p. [Also available at https://www.des.nh.gov/organization/divisions/ air/tsb/tps/climate/action_plan/documents/nhcap_final.pdf.]

Northeast Regional Climate Center, [undated], Data services: Northeast Regional Climate Center data, accessed August 2016 at http://www.nrcc.cornell.edu/services/access/ access.html.

Thom, A.S., and Oliver, H.R., 1977, On Penman's equation for estimating regional evaporation: Quarterly Journal of the Royal Meteorological Society, v. 103, p. 345-357.

U.S. Geological Survey, [undated], Welcome to the USGS geo data portal: U.S. Geological Survey data, accessed October 2015 at https://cida.usgs.gov/gdp/. 
Villa Nova, N.A., de Miranda, J.H., Pereira, A.B., and da Silva, K.O., 2006, Estimation of the potential evapotranspiration by a simplified penman method: Engineering Agriculture, v. 26, no. 3, p. 713-721.

Wake, Cameron, Burakowski, Elizabeth, Hayhoe, Katharine, and Stoner, Anne, 2014, Climate change in northern New Hampshire-Past, present, and future: Durham, N.H., University of New Hampshire, 76 p. [Also available at https://sustainableunh.unh.edu/sites/sustainableunh.unh.edu/ files/images/northernnhclimateassessment2014.pdf.]
Wooten, Adrienne, 2016, Characterizing uncertainties in climate projections to support regional decision-making: U.S. Geological Survey data release, accessed December 8, 2017, at https://www.sciencebase.gov/catalog/ item/580e45d5e4b0f497e794b5dc.

Yates, D.N., and Strzepek, K.M., 1994, Potential evapotranspiration methods and their impact on the assessment of river basin runoff under climate change: International Institute for Applied Systems Analysis Working Paper WP-94-46, 28 p. 

For more information about this report, contact: Director, New England Water Science Center U.S. Geological Survey

101 Pitkin Street

East Hartford, CT 06108

dc_nweng@usgs.gov or visit our website at https://newengland.water.usgs.gov

Publishing support provided by the Pembroke, Rolla, and West Trenton Publishing Service Centers 

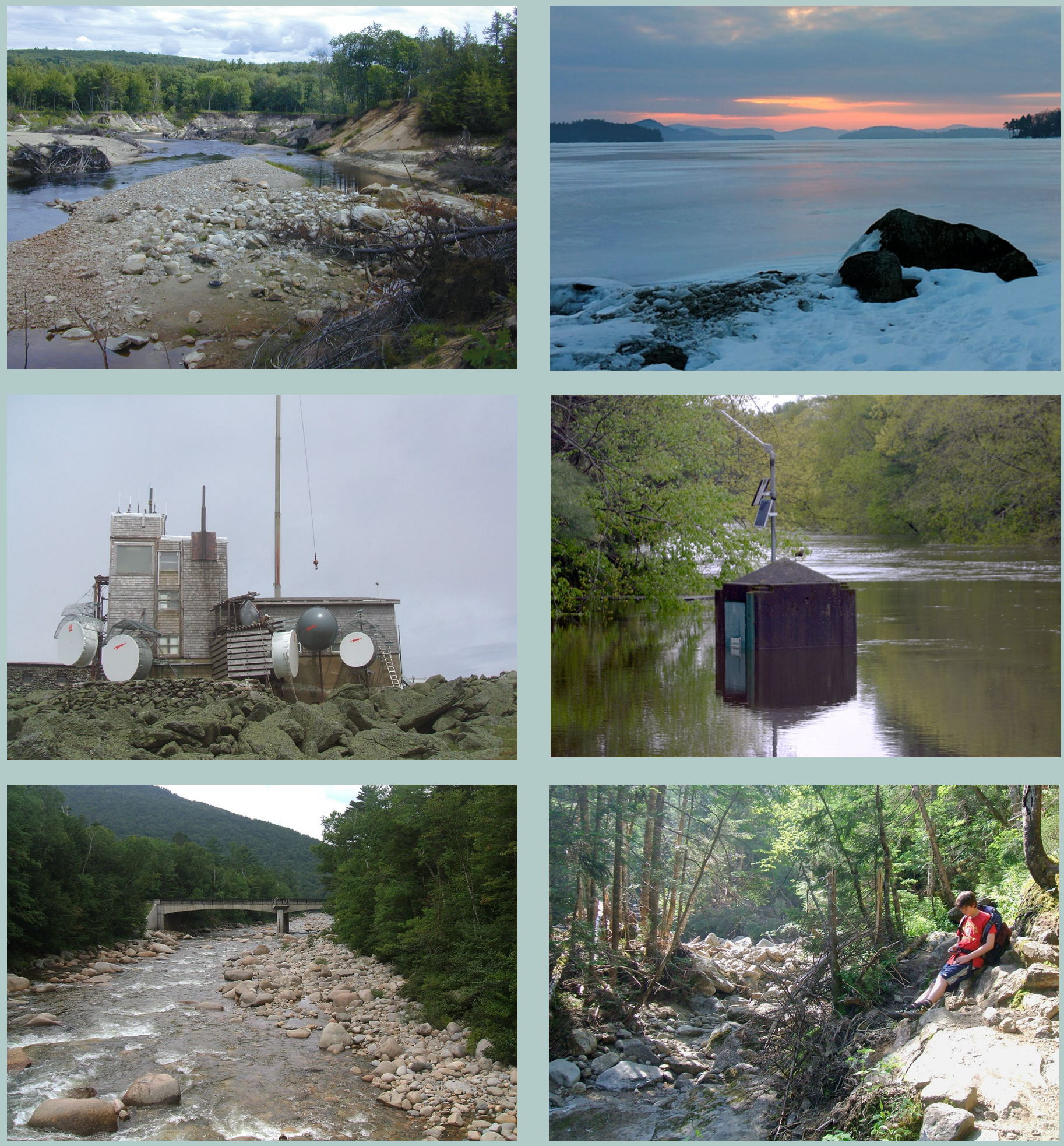

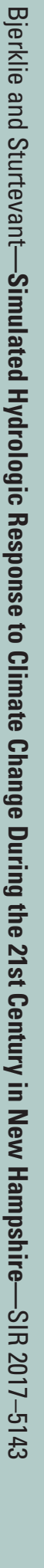

